UNIVERSIDADE DE SÃO PAULO

ESCOLA DE ENGENHARIA DE SÃO CARLOS

INSTITUTO DE FÍSICA DE SÃO CARLOS

INSTITUTO DE QUÍMICA DE SÃO CARLOS

\title{
CARACTERIZAÇÃo ELÉTRICA E MECÂNICA DE FITAS \\ ISOLANTES DE BLENDAS DE PVC
}

\author{
ANA CLÁUDIA RAMOS
}

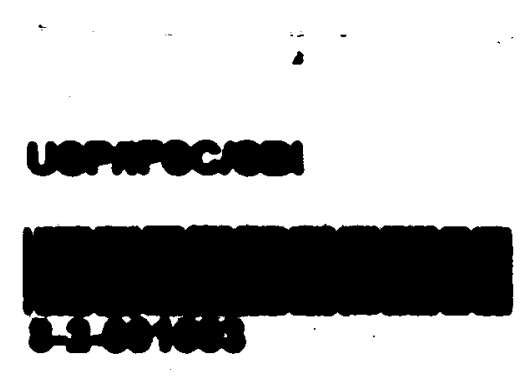

Dissertação apresentada à Área de Interunidades em Ciências e Engenharia de Materiais, da Universidade de São Paulo, como parte dos requisitos para a obtenção do Título de Mestre em Ciência e Engenharia de Materiais.

Orientador: Prof. Dr. José Alberto Giacometti Colaborador: Prof. Dr. Aldo Eloizo Job 
Ramos, Ana Cláudia

"Caracterização elétrica e mecânica de fitas isolantes de blendas de PVC" Ana Cláudia Ramos - São Carlos, 2004

Dissertação (Mestrado) - Interunidades Ciência e Engenharia de Materiais da Universidade de São Paulo, 2004 - páginas: 90

Área: Ciência e Engenharia de Materiais

Orientador: Prof. Dr. José Alberto Giacometti

1. Blendas de PVC

1. Título 
MEMBROS DA COMISSÃO JULGADORA DA DISSERTAÇÃO DE MESTRADO DE ANA CLÁUDIA RAMOS APRESENTADA AO INSTITUTO DE FISICA DE SÃO CARLOS, UNIVERSIDADE DE SÃO PAULO, EM 27-11-2003.

COMISSÃO JULGADORA:

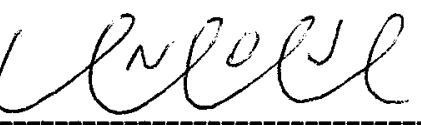

Prof. Dr. Osvaldo Novais de Oliveira Júnior - IFSC/USP

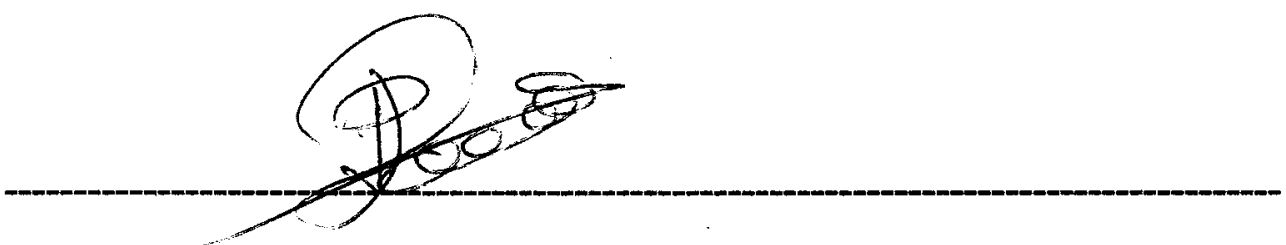

Prof. Dr. José Pedro Donoso Gonzalez - IFSC / USP

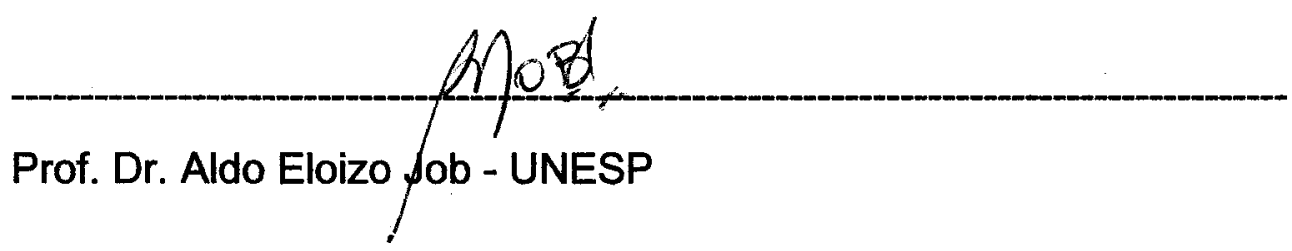


Ao meu marido Ricardo pelo amor e compreensão e aos meus pais Deolinda e Aldo pela oportunidade e sacrifícios. 


\section{AGRADECIMENTOS}

- Ao meu orientador Dr. José Alberto Giacometti, pela excelente orientação, apoio e paciência em todas as etapas deste trabalho.

- Ao Dr. Aldo Eloizo Job, do Departamento de Física, Química e Biologia da UNESP de Presidente Prudente pela parceria na execução deste trabalho.

- Ao Dr. Fábio Cézar Ferreira do Departamento de Física, Química e Biologia da UNESP de Presidente Prudente pela colaboração na realização das medidas de análise térmica.

- À $3 M$ do Brasil, pelo suporte para a execução deste trabalho e fornecimento dos materiais, em especial para Paulo Sérgio Pinto Catão, pela compreensão e apoio neste trabalho.

- Sinceros agradecimentos ao Benedito A. dos Santos (Pico) pela amizade, orientação, discussões e utilização dos equipamentos do Laboratório de Elétricos da 3M.

- Agradeço ao Luis Antonio Garcia, Juliano Francisco e Euclides C. Ribeiro do Laboratório de Elétricos da 3M pela ajuda no processamento dos materiais.

- Aos amigos da 3M: Karin, Aileen, Fernando, André, Gustavo, Telmo, Reginaldo, Valdir, AC, Patrícia, Luis, José Humberto, Fábio, Gilson, Marquinhos, Simone, Neto, Djebel, Luiz Alberto, Zezinho, pela amizade desprendida em todos estes anos. 
- Aos amigos do grupo de polímeros da USP: Carla, Clarissa, Patrícia, Valtencir, Flavia, Níbio pela amizade e convivência.

- À Erica e Wladerez, do Serviço de Pós-Graduação Interunidades da USP, pelos trabalhos prestados.

- Ao Ricardo, pelo carinho, compreensão e convivência em todos estes anos.

- A minha familia, especialmente aos meus pais, pelo apoio e luta que me proporcionaram esta oportunidade.

- Agradeço a todos aqueles que direta e indiretamente contribuíram para a realização deste trabalho. 
LISTA DE FIGURAS

LISTA DE TABELAS

LISTA DE ABREVIATURAS, SÍMBOLOS E SIGLAS

RESUMO

ABSTRACT

1 INTRODUÇÃO

2 REVISÃO BIBLIOGRÁFICA

2.1 POLICLORETO DE VINILA (PVC) 4

2.1.1 História da produção 4

2.1.2 Fabricaçăo do monómero 6

2.1.3 Polimerização do cloreto de vinila

$\begin{array}{ll}2.1 .4 \text { Caracterizaçäo do PVC } & 9\end{array}$

$\begin{array}{ll}2.1 .5 \text { Propriedades físicas } & 11\end{array}$

$\begin{array}{ll}2.1 .6 \text { Propriedades químicas } & 12 \\ & 14\end{array}$

$\begin{array}{ll}2.1 .7 \text { Classificação de resinas de PVC } & 14\end{array}$

2.2 PLASTIFICANTES 16

2.2.1 História da produção 16

2.2.2 Estabilidade da compatibilidade 17

$\begin{array}{ll}2.2 .3 \text { Classificaçăo dos plastificantes } & 19\end{array}$

$\begin{array}{ll}2.2 .4 \text { Propriedades da plastificação } & 20\end{array}$

2.3 MODIFICADORES DE IMPACTO 22

$\begin{array}{ll}2.4 \text { CARGAS } & 23\end{array}$

\begin{tabular}{ll}
2.5 \\
\hline PIGMENTOS & 24
\end{tabular}

2.6 OUTROS ADITIVOS $\quad 25$

2.7
DEGRADAÇÃO TÉRMICA DO PVC

3 MATERIAIS E MÉTODOS 30

$\begin{array}{ll}3.1 \text { MATERIAIS } & 30\end{array}$

$\begin{array}{ll}3.1 .1 \text { PVC } & 30\end{array}$

3.1.2 Plastificantes $\quad 30$

3.1.3 Modificador de impacto $\quad 32$

3.1.4 Carga $\quad 32$

3.1.5 Pigmento 32

3.1 .6 Outros aditivos 33 
3.1.6.1 Estabilizante térmico 33

3.1.6.2 Lubrificante $\quad 33$

3.1.6.3 Retardante de chama $\quad 33$

3.1.7 Formulação das amostras $\quad 34$

3.1.8 Preparação das amostras 36

3.2 MÉTODOS 39

3.2.1 Medidas térmicas $\quad 39$

3.2.1.1 Calorimetria exploratória diferencial (DSC) 39

3.2.1.2 Análise dinâmico-mecânica (DMA) 40

3.2.1.3 Análise termogravimétrica (TGA) 41

3.2.2 Medidas mecânicas $\quad 42$

3.2.2.1 Resistência à tração e alongamento $\quad 42$

$\begin{array}{ll}\text { 3.2.3 Medidas elétricas } & 44\end{array}$

$\begin{array}{ll}\text { 3.2.3.1 Rigidez dielétrica } & 44\end{array}$

$\begin{array}{ll}\text { 3.3 ANÁLISE ESTATISSTICA } & 45\end{array}$

4 RESULTADOS E DISCUSSÃO 48

4.1 MEDIDAS TÉRMICAS $\quad 48$

4.1.1 Calorimetria exploratória diferencial (DSC) 48

4.1.2 Análise dinâmico-mecánica (DMA) $\quad 49$

4.1.3 Análise termogravimétrica (TGA) 57

4.2
MEDIDAS MECÂNICAS

4.2.1 Resistência à tração e Alongamento $\quad 62$

$\begin{array}{ll}\text { 4.3 MEDIDAS ELÉTRICAS } & 74\end{array}$

$\begin{array}{ll}\text { 4.3.1 Rigidez Dielétrica } & 74\end{array}$

5 CONCLUSO̊ES

6 SUGESTŐES PARA TRABALHOS FUTUROS 82

7 ANEXOS

ANEXO A - Parâmetros de ajuste da máquina de tração Kratos para filmes de $\quad 83$ PVC.

ANEXO B - Leituras e medidas dos ensaios de resisténcia à tração e 84 alongamento.

ANEXO C - Leituras e medidas dos ensaios de tensão disruptiva.

8 REFERENNCIAS BIBLIOGRÁFICAS 88

$\begin{array}{ll}\text { GLOSSÁRIO } & 90\end{array}$ 
Figura 1 - Distribuição dos segmentos industriais das aplicações do polímero PVC.

Figura 2 - Reações envolvidas na formação do cloreto de vinila utilizando etileno e acetileno.

Figura 3 - Fluxograma de preparação de amostras.

Figura 4 - Foto do misturador intensivo Mecanoplast.

Figura 5 - Foto da calandra de dois rolos.

Figura 6 - Foto da prensa automática.

Figura 7 - Foto do equipamento de DSC.

40

Figura 8 - Foto do equipamento de DMA.

Figura 9 - Foto do equipamento de TGA.

Figura 10 - Foto da máquina de ensaio de tração Kratos.

Figura 11 - Foto do equipamento de medição da tensão disruptiva.

Figura 12 - Exemplo do gráfico "Boxplot".

Figura 13 - Termogramas de DSC para algumas amostras - Referência, Amostra 1.1 (0.0 PHR pigmento) e Amostra 2.6 (30.0 PHR carga).

Figura 14 - Curvas de DMA para as amostras com a variação do pigmento na composição (PHR).

Figura 15 - Curvas de Tan $\delta$ para as amostras com a variação do pigmento na composição (PHR).

Figura 16 - Valores da temperatura de transição vitrea ( $\mathrm{Tg})$ para as amostras com a variação do pigmento na composiçăo (PHR).

Figura 17 - Curvas de DMA para as amostras com a variação da carga na composiçăo (PHR).

Figura 18 - Curvas de Tan $\delta$ para as amostras com a variaçăo da carga na composição (PHR).

Figura 19 - Valores da temperatura de transição vítrea $(\mathrm{Tg})$ para a variação da carga na composição (PHR).

Figura 20 - Curvas de DMA para as amostras com a variaçăo do modificador de impacto na composição (PHR).

Figura 21 - Curvas de Tan $\delta$ para as amostras com a variação do modificador de impacto na composição (PHR). 
Figura 22 - Valores da temperatura de transição vítrea $(\mathrm{Tg})$ para a variação do modificador de impacto na composiçăo (PHR).

Figura 23 - Curvas de DMA para as amostras com a variação dos plastificantes na composição (PHR).

Figura 24 - Curvas de Tan $\delta$ para as amostras com a variação dos plastificantes na composição (PHR).

Figura 25 - Valores da temperatura de transição vítrea (Tg) para a variação dos plastificantes na composiçăo (PHR).

Figura 26 - Curvas termogravimétricas para as amostras com a variação do pigmento na composição (PHR).

Figura 27 - Curvas termogravimétricas para as amostras com a variação da carga na composiçăo (PHR).

Figura 28 - Correlação entre a variação da carga na composição das amostras (\%) e a massa residual após os ensaios de TGA (\%).

Figura 29 - Curvas termogravimétricas para as amostras com a variação do modificador de impacto na composição (PHR).

Figura 30 - Curvas termogravimétricas para as amostras com a variação dos plastificantes na composiçăo (PHR).

Figura 31 - Gráfico dos valores de resistência à tração $(\mathrm{Kgf} / \mathrm{mm})$ em relação à variação do pigmento na composiçăo (PHR).

Figura 32 - Gráfico "Boxplot" da resistência à tração $(\mathrm{Kgf} / \mathrm{mm})$ versus a variaçăo do pigmento (Amostra 1.1 a Amostra 1.6 e Referência).

Figura 33 - Gráfico dos valores de alongamento $(\% / \mathrm{mm})$ em relação à variação do pigmento na composiçăo (PHR).

Figura 34 - Gráfico "Boxplot" do alongamento (\%/mm) versus a variaçăo do pigmento (Amostra 1.1 a Amostra 1.6 e Referéncia).

Figura 35 - Gráfico dos valores de resistência à tração $(\mathrm{Kgf} / \mathrm{mm})$ em relação à variação da carga na composiçăo (PHR).

Figura 36 - Gráfico "Boxplot" da resistência à traçāo $(\mathrm{Kgf} / \mathrm{mm})$ versus a variação da carga (Amostra 2.1 a Amostra 2.6 e Referência).

Figura 37 - Gráfico dos valores de alongamento $(\% / \mathrm{mm})$ em relação à variação da carga na composiçăo (PHR).

Figura 38 - Gráfico "Boxplot" do alongamento $(\% / \mathrm{mm})$ versus a variação da carga (Amostra 2.1 a Amostra 2.6 e Referéncia).

Figura 39 - Gráfico dos valores de resisténcia à tração $(\mathrm{Kgf} / \mathrm{mm})$ em relação à variação do modificador de impacto na composição (PHR).

Figura 40 - Gráfico "Boxplot" da resistência à traçăo $(\mathrm{Kgf} / \mathrm{mm})$ versus a variação do modificador de impacto (Amostra 3.1 a Amostra 3.6 e Referéncia). 
Figura 41 - Gráfico dos valores de alongamento $(\% / \mathrm{mm})$ em relação à variação do modificador de impacto na composição (PHR).

Figura 42 - Gráfico "Boxplot" do alongamento $(\% / \mathrm{mm})$ versus a variação do modificador de impacto (Amostra 3.1 a Amostra 3.6 e Referência).

Figura 43 - Gráfico dos valores de resistência à tração $(\mathrm{Kgff} / \mathrm{mm})$ em relação à variaçăo dos plastificantes na composição (PHR).

Figura 44 - Gráfico "Boxplot" da resistência à tração $(\mathrm{Kgf} / \mathrm{mm})$ versus a variação dos plastificantes (Amostra 4.3 a Amostra 4.6 e Referência).

Figura 45 - Gráfico dos valores de alongamento $(\% / \mathrm{mm})$ em relação à variação dos plastificantes na composiçäo (PHR).

Figura 46 - Gráfico "Boxplot" do alongamento $(\% / \mathrm{mm})$ versus a variação dos plastificantes (Amostra 4.3 a Amostra 4.6 e Referência).

Figura 47 - Gráfico dos valores de rigidez dielétrica (volts $/ \mathrm{mm}$ ) em relação à variação do pigmento na composição (PHR).

Figura 48 - Gráfico "Boxplot" da rigidez dielétrica (volts $/ \mathrm{mm}$ ) versus a variação do pigmento (Amostra 1.1 a Amostra 1.6 e Referência).

Figura 49 - Gráfico dos valores de rigidez dielétrica (volts $/ \mathrm{mm}$ ) em relação à variação da carga na composiçăo (PHR).

Figura 50 - Gráfico "Boxplot" da rigidez dielétrica (volts/mm) versus a variação da carga (Amostra 2.1 a Amostra 2.6 e Referéncia).

Figura 51 - Gráfico dos valores de rigidez dielétrica (volts $/ \mathrm{mm}$ ) em relação à variação do mdificador de impacto na composiçăo (PHR).

Figura 52 - Gráfico "Boxplot" da rigidez dielétrica (volts $/ \mathrm{mm}$ ) versus a variação do modificador de impacto (Amostra 3.1 a Amostra 3.6 e Referência).

Figura 53 - Gráfico dos valores de rigidez dielétrica (volts $/ \mathrm{mm}$ ) em relaçăo à variação dos plastificantes de impacto na composiçăo (PHR). plastificantes (Amostra 4.3 a Amostra 4.6 e Referência). 
Tabela I - Formulaçăo referencial (PHR) - tipo Amostra Referência. 34

Tabela II - Composição da formulação tipo Amostra 1 - Variação do 34 pigmento (PHR).

Tabela III - Composição da formulação tipo Amostra 2 - Variação da carga (PHR).

Tabela IV - Composição da formulação tipo Amostra 3 - Variação do 35 modificador de impacto (PHR).

Tabela V - Composição da formulação tipo Amostra 4 - Variação dos plastificantes (PHR). 
ABS - acrilonitrila-butadieno-estireno

ANOVA - "analysis of variance"

ASTM - "American Society for Testing and Materials"

$\mathrm{Cl}$ - cloro

CPE - polietileno clorado

DIDA - diisodecil adipato

DOP - dioctil ftalato, di-2-etilexil ftalato

DSC - calorimetria exploratória diferencial

DMA - análise dinâmico mecânica

GPC - cromatografia por permeação em gel

$H$ - hidrogênio

$\mathrm{HCl}$ - ácido cloridrico

HIPS - poliestireno butadieno de alto impacto

MEV - microscopia eletrônica de varredura

NBR - Norma Brasileira

PAN - poliacrilonitrila

PB - polibutadieno

PBT - poli (tereftalato de butileno)

PHR - "parts per hundred" - quantidade em massa do material incorporado na formulação do composto de PVC, em relação a 100 unidades de massa da resina (polímero).

PS - poliestireno

PU - poliuretano 
PVC - policloreto de vinila

SAN - poliestireno acrilonitrila

$\mathrm{Tg}$ - temperatura de transição vitrea

TGA - análise termogravimétrica

UR - umidade relativa do ar

UV - ultravioleta 
O policloreto de vinila (PVC) é comercialmente utilizado em diversas aplicações, destacando-se os filmes flexíveis. Para a fabricação destes compostos de PVC, utilizam-se vários tipos de aditivos, tais como plastificantes, estabilizantes térmicos, lubrificantes, retardantes de chama e outros. No presente trabalho foram produzidos compostos de PVC a partir de uma formulação referencial, variando-se a concentração de pigmento, carga, modificador de impacto e plastificantes. A preparação das amostras foi feita através de uma misturadeira intensiva (Mecanoplast), calandra de 2 rolos e prensa, obtendo-se placas flexíveis de $1 \mathrm{~mm}$ de espessura. Os resultados das análises térmicas (DMA e TGA) mostraram que o uso e a quantidade de plastificantes foram os principais fatores que influenciaram as propriedades de mudança de fase ( $\mathrm{Tg})$ e estabilidade térmica do material. As análises das propriedades mecânicas (resistência à tração e alongamento) mostraram que estas propriedades foram influenciadas pelas proporções de cargas, modificador de impacto e plastificantes na composição. As medidas elétricas (rigidez dielétrica) não foram afetadas pela variação da adição de materiais nas amostras analisadas. 


\section{ABSTRACT}

Poly(vinyl chloride) (PVC) is commercially used in several applications, especially in flexible films. Aiming the production of products, PVC can be filled with a variety of additives, like plasticizers, thermal stabilizers, lubricants, flame-retardants and others. In this work PVC compounds were produced based on a known formulation, using different weight ratios for pigment, filler, impact modifier and plasticizers. Samples were prepared through intensive mixing using two rolls calender followed by a hot press to form films with $1 \mathrm{~mm}$ thickness. Thermal analysis results (DMA and TGA) showed that plasticizers are the most important factors that influenced the material properties such as phase behavior $(\mathrm{Tg})$ and thermal stability. Mechanical properties analysis (breaking strength and elongation) were influenced by fillers, impact modifier and plasticizers proportions used in the composition. Electrical properties (dielectric breakdown strength) weren't affected by different weight ratios in the analyzed samples. 
O policloreto de vinila (PVC) é importante comercialmente devido ao seu baixo custo de produção e ao seu extensivo uso em diferentes formulações ou blendas, possibilitando diversas aplicações, destacando-se os filmes flexiveis. O PVC também apresenta ótimas propriedades de isolação elétrica, sendo amplamente utilizado na fabricação de produtos específicos do mercado eletro-eletrônico, tais como revestimentos para fios e cabos, fitas isolantes, etc ${ }^{(1)}$.

Para a fabricação de compostos de PVC, utilizam-se vários tipos de aditivos, tais como, plastificantes, estabilizantes térmicos, lubrificantes, retardantes de chama e outros. Os plastificantes largamente empregados são óleos poliméricos e monoméricos, ou combinações deles, que além de conferir flexibilidade ao material (alongamento, resistência) produzem a estabilização do composto final ${ }^{(2)}$. Esta estabilização se refere ao grau de degradação do material relacionada à migração dos plastificantes, para outras camadas em contato com a superfície do composto de PVC. No caso de fitas isolantes para isolação elétrica a migração pode ocorrer para a camada de adesivo da fita que a torna um produto de baixa qualidade quando consumida após ter sido estocada por períodos que podem ser considerados relativamente curtos. Este mecanismo ocorre pela ação do 
tempo e temperatura e, provavelmente é devido ao balanceamento incorreto das quantidades de plastificantes utilizadas.

Alternativas de materiais para substituir total ou parcialmente estes plastificantes podem reduzir este tipo de degradação. Blendas de PVC e poliuretano (PU) ${ }^{(3,4)}$, PVC e polietileno clorado (CPE) ${ }^{(5,6)}$, PVC e acrilonitrilabutadieno-estireno $(A B S)^{(7,8)}$, poli (tereftalato de butileno) $(P B T)$ e $A B S^{(9)}$ tem sido muito estudadas. O enfoque de tais estudos tem sido as propriedades de compatibilidade destes materiais para formar blendas e não com o propósito de aplicações em isolação elétrica.

$\mathrm{Na}$ indústria de fabricação de filmes de PVC com a finalidade de produzir fitas isolantes elétricas, além das matérias-primas que conferem as propriedades desejadas, existem vários parâmetros de processo que controlam as características do produto final, atendendo uma determinada especificação. Desvios destas especificações ocorrem com certa freqüência, porém os esforços despendidos para solucionar estes problemas muitas vezes não levam ao entendimento das causas raízes. Os sistemas de qualidade implementados em muitas indústrias formalizam as práticas e as rotinas de determinada empresa, não garantindo uma real investigação para se obter as soluções, como uma metodologia de caracterização para o real entendimento do produto.

O objetivo do presente trabalho foi estudar novas formulações no que se refere a sua aplicação em fitas isolantes, utilizando metodologias de caracterizações elétrica, térmica e mecânica. A obtenção de amostras baseou-se em uma formulação referencial utilizada industrialmente, 
realizando-se um planejamento de experimentos variando a concentração de algumas matérias-primas.

No capítulo 2 é apresentada a revisão bibliográfica dos principais compostos utilizados em formulações de PVC flexíveis e também possiveis materiais alternativos para a fabricação de filmes vinílicos. No capitulo 3 são descritos os materiais utilizados, o planejamento de experimentos, os equipamentos para a obtenção das amostras e os métodos de análises utilizadas para a caracterização das formulações e das fitas isolantes. Os dados obtidos nas análises das caracterizaçōes físicas e térmicas das amostras estão mostrados no capítulo 4 e os dados experimentais podem ser encontrados no Anexo. Finalizando, no capítulo 5 são apresentadas as conclusões deste trabalho. 


\section{REVISÃO BIBLIOGRÁFICA}

\subsection{POLICLORETO DE VINILA (PVC)}

\subsubsection{História da produção}

O desenvolvimento da resina de PVC iniciou quando o monômero cloreto de vinila foi descoberto por Justus Von Liebig em 1835. Em 1839, um aluno de Liebig, Victor Regnault, publicou um artigo relatando a ocorrência da polimerização deste monômero. Estudos posteriores mostraram que o polímero era o poli (cloreto de vinilideno). Somente em 1872 o PVC foi preparado por E. Baumann. Em 1912, Fritz Klatte descobriu um procedimento básico para a produção comercial do PVC, na empresa onde trabalhava, a Chemische Fabrik Griesheim - Elektron, porém o produto não obteve nenhum sucesso até 1926. Uma das contribuições significativas no desenvolvimento de PVC como plástico com importância industrial foi a descoberta de Waldo L. Semon, em 1926; o polímero podia ser flexibilizado como uma peça de borracha ou couro, pelo aquecimento na presença de certos ésteres com alto ponto de ebulição, chamados então de plastificantes. A produção em escala comercial do PVC começou nos Estados Unidos nos anos 20, na Alemanha nos anos 30 e somente nos anos 40 teve início a produção britânica. A primeira produção do PVC no Brasil ocorreu em 1954. A produção anual do PVC excedeu 400 toneladas em 1935. Em 1979, a 
produção dos EUA foi mais de 2,5 milhões de toneladas por ano. Em 2001, o PVC foi o segundo termoplástico mais consumido no mundo, com mais de 27 milhões de toneladas por ano (22\% EUA, 22\% Europa Ocidental, 7\% Japão, 2,5\% Brasil, 46,5\% outros países). A capacidade instalada atualmente das empresas no mundo é da ordem de 31 milhões de toneladas por ano ${ }^{(14)}$. Com o crescimento acelerado do seu uso, o PVC é atualmente um dos polímeros de menor custo e maior versatilidade no mercado mundial de termoplásticos. A utilização de aditivos permite a produção de produtos rígidos e flexíveis, é usado como resina pura ou em blendas na produção de perfis, chapas, filmes, tubos, cabos, couro sintético etc. A distribuição das aplicações industriais do PVC está detalhada na Figura $1^{(10,11,12)}$.

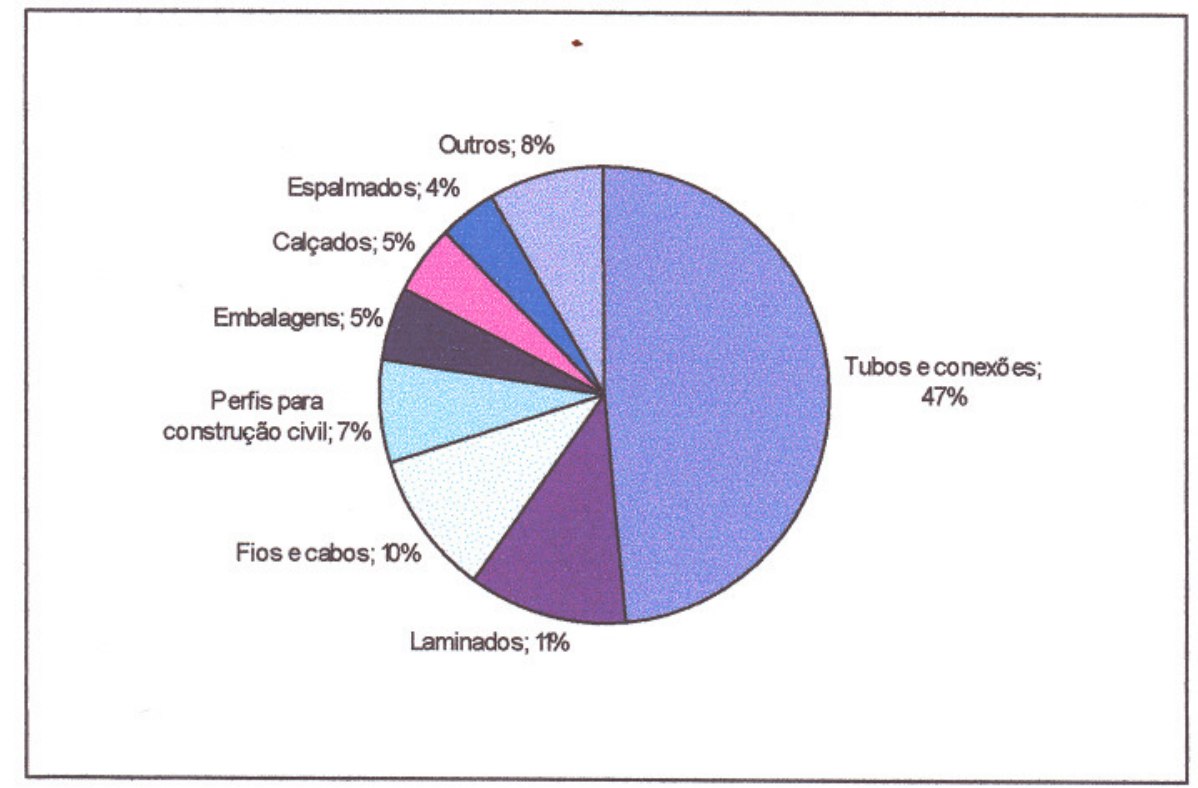

Figura 1 - Distribuição dos segmentos industriais das aplicações do polímero PVC. 


\subsubsection{Fabricação do monômero}

O monômero cloreto de vinila é incolor e gasoso a temperaturas normais. Ele é solúvel em hidrocarbonetos alifáticos e aromáticos, ésteres, cetonas, éteres, álcoois, em solventes clorados e insolúveis em água. $\mathrm{Na}$ fabricação do monômero cloreto de vinila podem ser usados dois tipos de matérias-primas: etileno $\left(\mathrm{C}_{2} \mathrm{H}_{4}\right)$ ou acetileno $\left(\mathrm{C}_{2} \mathrm{H}_{2}\right)$. O etileno é utilizado em 93\% da produção comercial do monômero, e esta reação é mostrada na Figura 2.

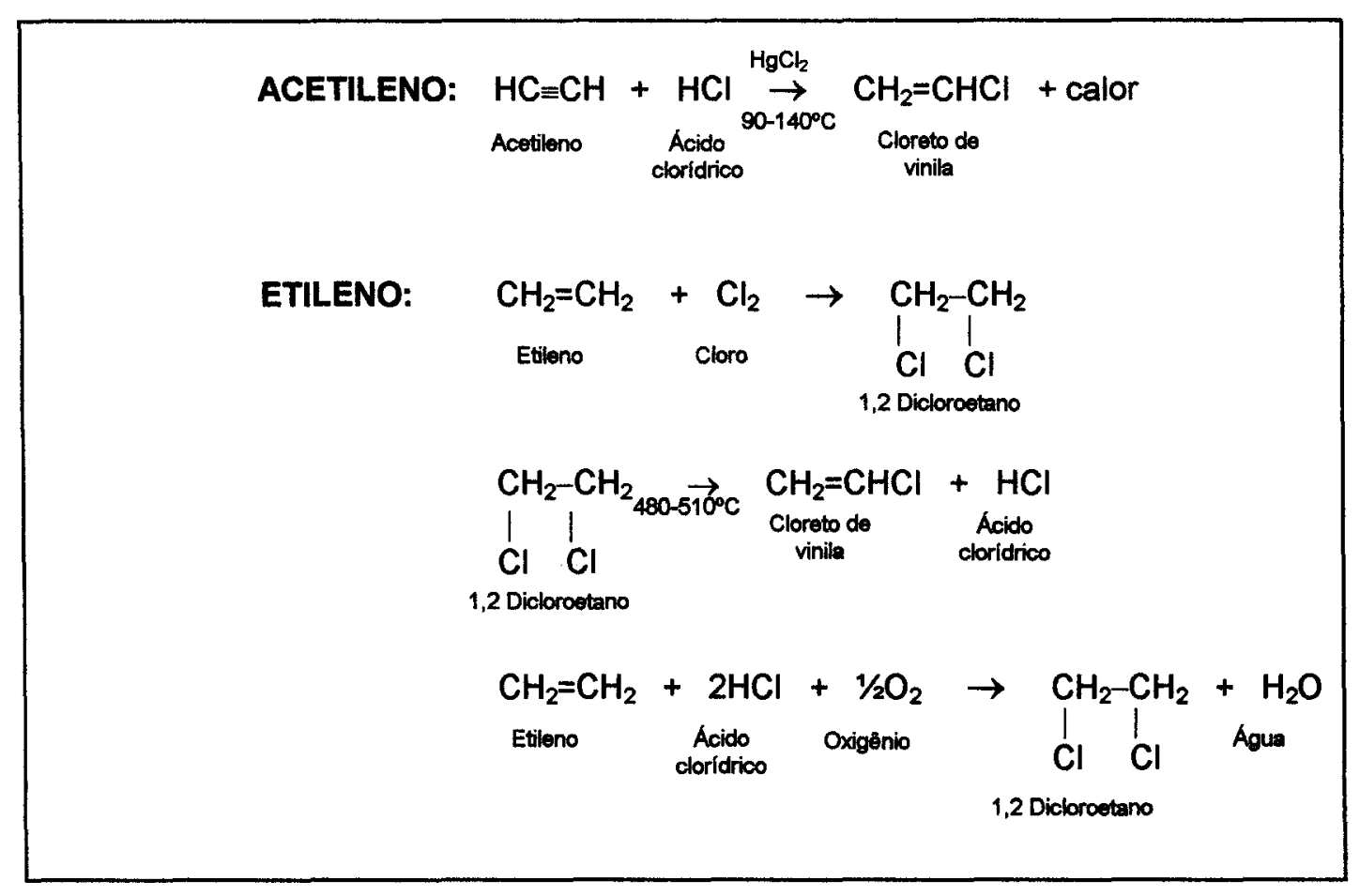

Figura 2 - Reações envolvidas na formação do cloreto de vinila utilizando etileno e acetileno.

Outros processos podem ser utilizados para a obtenção do monômero. O balanço das reações com acetileno e etileno faz com que o ácido clorídrico $(\mathrm{HCl})$ produzido na reação via etileno reaja com o acetileno, reduzindo a quantidade deste. Desta forma, este balanceamento atende as 
economias em matéria-prima e o uso do $\mathrm{HCl}$. Outra forma de obtenção é a partir do etano, mais barato e mais facilmente disponivel do que o etileno e o acetileno, que envolve o craqueamento do etano para etileno, o qual é simultaneamente clorado, oxiclorado e desiclorado usando o oxicloreto de cobre como carregador de oxigênio ${ }^{(10)}$.

\subsubsection{Polimerização do cloreto de vinila}

Na polimerização do cloreto de vinila, cerca de $78 \%$ do PVC produzido pelos EUA é feito pelo processo de suspensão, e o restante pelo processo de emulsão. $\mathrm{Na}$ Europa as quantidades têm valores similares.

A fórmula química do polímero obtido é:

$$
-\left(\begin{array}{cc}
H & H \\
- & 1 \\
-C & -C- \\
1 & 1 \\
H & C l
\end{array}\right)_{n}-
$$

O processo em suspensão, também chamado de polimerização perolada ou granular, envolve a polimerização catalisada por radicais livres de porções discretas do monômero suspenso em água por agitação e um colóide protetor (gelatina, metilcelulose e álcool polivinílico). A quantidade e o tipo do sistema de suspensão é muito importante na determinação do tamanho de partícula, forma, porosidade e distribuição de tamanho. Agentes modificadores, como exemplo, para ajustes de $\mathrm{pH}$, devem ser cuidadosamente selecionados. Num processo típico de suspensão o agente de suspensão é dissolvido em água deionizada e desaerada e adicionada num reator de vidro ou aço inox. O restante da água, catalisador e outros aditivos são também adicionados. O reator, que é encamisado e agitado, é 
vedado e evacuado para remover o oxigênio, e então o monômero liquefeito é adicionado. O controle de temperatura é necessário para regular o peso molecular. A polimerização é continuada a temperatura constante até que a pressão caia, devido à redução do monômero. A lama do polímero sai com o residual do monômero, é resfriada e centrifugada e seco. $O$ fator mais determinante do sucesso de plantas de produção de PVC é a maximização do processo de remoção do calor exotérmico balanceado pelo controle cinético. Isto depende da escolha do sistema catalítico. A operação ótima do reator envolve o rápido início da reação, a manutenção da polimerização isotérmica e a terminação sem a característica exotérmica (liberação de calor).

O peso molecular do polímero formado é uma função da reação usada durante a polimerização. Baixas temperaturas favorecem o aumento dos pesos moleculares. Homopolimeros de PVC com baixos pesos moleculares são produzidos em altas temperaturas de reação. São mais difíceis de separar dos residuais do monômero e secam em níveis baixos de volatilidade. Quando a temperatura de polimerização aumenta, a qualidade do polímero piora, assim, para a operação segura é usada a faixa de 71 a 77 ${ }^{\circ} \mathrm{C}$ de temperatura máxima. Se o peso molecular baixo é desejado, é melhor usar agentes reguladores do que temperaturas altas ${ }^{(10)}$.

O processo em emulsão também envolve a dispersão do monômero em meio aquoso, porém é necessário o uso de um agente surfactante ativo como emulsificador e catalisador solúvel em água, ao contrário da suspensão que é solúvel no monômero. Mesmo sendo a agitaçăo necessária, ela não é tão importante como no processo de suspensão, pois a emulsão é mantida 
pelo uso do surfactante e colóides protetores para garantir a estabilidade do látex produzido. Os equipamentos usados são similares aos empregados na suspensão e após a recuperação do monômero a resina é separada por secagem pulverizada. Partículas da resina de emulsão têm cerca de $1 \mu \mathrm{m}$ de diâmetro e uma distribuição de tamanho de partícula muito estreita; produto este indicado para aplicações de plastisol ${ }^{(10)}$.

O processo "in bulk" é conduzido pela ausência de diluentes. A remoção de calor é feita pela quebra de um grande bloco de polímero por eixos na horizontal (autoclave). A reação inicia num reator vertical com agitação rápida até $10 \%$ da conversão, quando então o reator cai para a posição horizontal com agitação lenta ${ }^{(10)}$.

O processo em solução envolve a adição de um solvente no sistema de polimerização. O sistema pode ser heterogêneo, no qual o monômero é solúvel, mas o polímero não. Em reações homogêneas ambos são solúveis. Este tipo é mais usado para produção de copolimeros de cloreto de vinila e acetato de vinila, e terpolímeros ${ }^{(10)}$.

\subsubsection{Caracterização do PVC}

O processo de polimerização resulta em moléculas com uma variedade de comprimentos de cadeia ou pesos moleculares.

As ramificações em PVC, que ocorrem pelo mecanismo de transferência de cadeia, são dependentes das condições de polimerização. Num sistema heterogêneo, com uma alta concentração localizada do polímero, as ramificações podem ser esperadas numa freqüência relativamente alta. Em temperaturas baixas de polimerização o grau de 
ramificação é baixo. Mudanças nas propriedades físicas, tais como a densidade, o ponto de fusão e a temperatura de transição vítrea $(\mathrm{Tg})$, têm sido freqüentemente atribuídas às ramificações, mas na realidade elas são determinadas pela sindiotaticidade ou cristalinidade do polímero ${ }^{(10)}$.

O pesquisador $\mathrm{H}$. Staudinger foi o primeiro a reconhecer o conceito de estereoregularidade em polímeros vinílicos. O PVC pode ser representado como uma cadeia de átomos de carbono no plano com átomos ligados nos planos acima e abaixo deste. A maior parte do PVC produzido é atático e a regularidade necessária para as cadeias se empacotarem e terem cristalinidade não existe. O PVC é altamente amorfo com um grau de cristalinidade muito baixo associado a seqüências sindiotáticas $( \pm 10 \%$ de cristalinidade). Porém se a polimerização é feita em temperaturas baixas, ocorre um aumento na cristalinidade do PVC ${ }^{(10)}$. Se considerarmos que o grupo metileno do PVC é a cauda da molécula e o carbono com cloro a cabeça da molécula, existem três possibilidades da estrutura da molécula: cabeça-cauda, cabeça-cabeça e cauda-cauda.

Numa mistura complexa de sólidos particulados com aditivos, a absorção destes aditivos será influenciada pela forma, tamanho e distribuição das partículas de PVC, as quais afetam a densidade de empacotamento, fluidez e processabilidade do material. Fusão ou geleificação inadequadas causam defeitos estruturais e características de performance não desejadas.

Estudos de resinas comerciais de PVC produzidas pelo processo de suspensão podem ser feitos empregando-se as técnicas de Cromatografia por Permeação em Gel (GPC), Microscopia Eletrônica de Varredura (MEV), 
área superficial e porosidade para analisar a morfologia e distribuição de peso molecular ${ }^{(11)}$. Numa micrografia é possível perceber micropartículas e poros externos dos grânulos de PVC, a superfície é bastante irregular e de acordo com a literatura, a partícula de PVC pode ser descrita como uma estrutura aglomerada de micropartículas $(1 \mu \mathrm{m})$ formando os grãos (100 $200 \mu \mathrm{m})$. Existe uma correlação direta entre a área superficial da partícula e - peso molecular médio. A habilidade da resina de PVC na absorção de plastificantes é avaliada através do tempo em que a resina absorve estes aditivos, afetando suas características de fusão. Quanto maior o volume ou diâmetro de poros, maior a velocidade da resina de absorver o plastificante ${ }^{(11)}$. Partículas maiores têm relativa uniformidade no tamanho e são geralmente preferidas. Partículas muito finas prejudicam a absorção de plastificantes, porém muito grandes não absorvem completamente 0 plastificante, não fluem facilmente e formam partículas de gel ou aglomerados ("fish eyes").

\subsubsection{Propriedades físicas}

O PVC é duro, frágil à temperatura ambiente. Produtos plastificados flexíveis possuem um grande espectro de propriedades desejadas.

Plastificantes têm um efeito marcante no valor da $\mathrm{Tg}$ de um polímero. Ë esperado que o polímero plastificado tenha menor resistência à tração, dureza e módulo de elasticidade do que o material puro. A incorporação de pequenas quantidades de plastificantes, como dioctil ftalato (DOP), no PVC causa um aumento nos valores dessas grandezas. Em níveis de 10 a 15\%, medidas de raios- $\mathrm{X}$ e infravermelho mostram um aumento de cristalinidade, 
provavelmente pela ordenação das cadeias do polímero. Este resultado depende do tipo de plastificante. Se a quantidade aumenta, entretanto, estas propriedades diminuem.

O ponto de fusão do PVC também depende da temperatura de polimerização. Devido a decomposição do polímero ser muito rápida em temperaturas elevadas, o ponto de fusão não pode ser medido por técnicas diretas. Reding e colaboradores usaram técnicas de extrapolação na qual o módulo de rigidez foi medido em função da temperatura para diferentes concentrações de DOP adicionado ao PVC. O ponto de fusão foi determinado na temperatura que o módulo atingiu o valor de $10 \mathrm{lb} / \mathrm{in}^{2}$. $\mathrm{O}$ gráfico do módulo de rigidez versus concentração de plastificante foi extrapolado para $0 \%$ de plastificante e assim 0 ponto de fusão para 0 material puro foi obtido ${ }^{(10)}$.

\subsubsection{Propriedades químicas}

As principais propriedades químicas estão descritas nos tópicos abaixo $^{(10)}$.

- Desidrocloração térmica: o PVC é instável e em moderadas temperaturas começa a decomposição com perda de $\mathrm{HCl}$. $\mathrm{O}$ sucesso do desenvolvimento comercial levou ao desenvolvimento da complexa tecnologia de estabilizantes que neutralizassem $0 \mathrm{HCl}$ desprendido e resultasse na melhoria da cor do composto, podendo o mesmo ser processado com outros termoplásticos. Foi proposto no início que o $\mathrm{HCl}$ era perdido primeiro de posições onde o cloro estava mais exposto e devido sua localização em posições adjacentes às duplas ligações. Cada estrutura 
resultante da perda do $\mathrm{HCl}$ cria uma dupla ligação, a qual faz que o cloro adjacente se torne exposto. A subseqüente perda do $\mathrm{HCl}$ é catalisada pelo próprio $\mathrm{HCl}$ e é descrito como autocatalítico, produzindo duplas ligaçōes alternadas (reação em ziper). A presença de oxigênio no ambiente de degradação do PVC acelera a perda de $\mathrm{HCl}$. Este resultado pode ser baseado pelo ataque o oxigênio das estruturas conjugadas de polieno para oxigená-las e simultaneamente formando estruturas oxigenadas que expõe os átomos de $\mathrm{Cl}$ adjacentes ${ }^{(10)}$.

- Desicloração química: o tratamento de PVC com certos reagentes químicos resulta na completa perda de $\mathrm{HCl}$ e um produto com fórmula empírica $(\mathrm{CH}=\mathrm{CM})_{n}$, um polieno.

- Radiação: o PVC também é degradado por irradiação, resultando em descoloração, cadeias rompidas e ligações cruzadas. $\mathrm{O} \mathrm{HCl}$ é desprendido durante o processo como medida direta ou estabelecido pelo fato que estabilizantes básicos são gradualmente convertidos para a forma de cloretos. Foi estudado que $\mathrm{HCl}$ é somente liberado quando luz de comprimentos de onda menores que $340 \mathrm{~nm}$ são usados; a quantidade de $\mathrm{HCl}$ formado aumenta com a diminuição do comprimento de onda. A fotodegradação do PVC provavelmente segue um mecanismo de formação de radicais, no qual traços de impureza e resíduos de catalisador são provavelmente as fontes iniciais da absorção da radiação e formação do radical.

- Desenvolvimento da cor: o espectro de absorção em regiões visiveis do PVC para degradações térmicas mostra vários máximos que relacionam o grau de conjugação dos polienos formados por desidrocloração. 
- Ligações cruzadas: quando o PVC é aquecido em solução, não somente perde $\mathrm{HCl}$, mas também ocorrem ligações cruzadas e resultam eventualmente em um gel insolúvel. A teoria da geleificação, o ponto de gel, correspondente a formação de uma infinita rede, é alcançada quando uma ligação cruzada por molécula de polímero inicial presente se forma.

- Hidrogenação: cerca de $97 \%$ do H presente no PVC pode ser reposto por hidrogenações em tratamentos do polímero com hidrido de alumínio e lítio.

- Cloração: resulta um produto com $73 \%$ de $\mathrm{Cl}$, o que corresponde à introdução de um cloro por átomo de carbono. Polímeros pós-clorados têm alcançado alguma importância industrial, pois eles têm menores temperaturas de amolecimento e maior solubilidade em vários solventes.

\subsubsection{Classificação de resinas de PVC}

As resinas de PVC são classificadas baseadas na forma física e nos processos de fabricação nos quais são obtidas ${ }^{(10)}$.

- Resinas de uso geral: homopolímeros e copolímeros de PVC podem ser produzidos por processos em suspensão, emulsão, "in bulk" ou solução, e, representam $90 \%$ do total de PVC produzido. Estas resinas são convertidas em produtos usando calandragem, extrusão, injeção e moldagem por sopro.

Algumas propriedades consideradas significantes pelas normas ASTM para estes tipos de resina são: peso molecular, tamanho de partícula, densidade, absorção de plastificantes, fluxo de secagem e condutividade elétrica (depende da quantidade de água extraível presente na resina, resulta 
de impurezas iônicas e polares que afetam o uso da resina para isolamentos elétricos).

- Resinas de dispersão: estes materiais são utilizados em plastisóis ou organosóis e tem tamanho de partícula muito fina, na faixa de 0,1 até $2 \mu \mathrm{m}$. As resinas são obtidas pela polimerização em emulsão seguida pela secagem pulverizada.

Algumas propriedades consideradas significantes pelas normas da ASTM para estes tipos de resina são: viscosidade do plastisol, tamanho de partícula (tamanhos menores resultam em viscosidade maior do plastisol, mas confere pouca estabilidade da viscosidade, porém partículas maiores fundem mais devagar e pioram a performance das propriedades), fusão do plastisol, desprendimento de $\operatorname{ar}^{(10)}$.

- Resinas blendadas: são copolímeros de cloreto de vinilideno de homopolímeros polimerizados em suspensão que tem tamanho de partícula de 10 a $100 \mu \mathrm{m}$ e são usados como extensores em resinas de plastisol para reduzir custos.

- Resinas de soluções: são usadas em aplicações de cobrimento de superficies.

- Látex: são dispersões de homopolímeros e copolímeros em água que são produzidos por polimerização aniônica e contem $50 \%$ de sólidos. 


\subsection{PLASTIFICANTES}

\subsubsection{História da produção}

O desenvolvimento da tecnologia de plastificantes iniciou-se cedo e progrediu com a comercialização de resinas plastificadas. A história dos plastificantes para resinas data de 1846 quando Schenbein preparou nitrato de celulose, o que forneceu a tecnologia de produção de uma resina que fosse controlada pela plastificação. O primeiro composto plastificado foi feito por Alexander Parker, quando ele fez o "Parkesine", o precursor da Celluloid. Seu processo envolveu a dissolução do nitrato de celulose em solvente, mistura em óleo e transporte por solvente. Mas esta última etapa foi ineficaz, o plastificante era volátil e o resultado foi desastroso. Parker desenvolveu então o seguinte princípio: 'Um plastificante tem que ser um 'solvente' com alto ponto de ebulição".

Em 1870, John Wesley Hyatt patenteou o uso de um excelente plastificante para nitrato de celulose, cânfora (Celluloid). Pesquisadores começaram a estudar acetato de celulose como um polímero menos inflamável e analisaram centenas de substâncias para encontrar um plastificante que fosse análogo a performance da cânfora na Celluloid. Em 1910, a companhia Celluloid patenteou o uso de fosfato trifenil em combinação com acetato de celulose para prevenir o perigo da alta flamabilidade inerente do nitrato de celulose.

$\mathrm{Na}$ década de 1920, fosfato de tricresil e ésteres ftálicos estavam em voga para a plastificação natural em fórmicas, ceras e celuloses. Em 1929, Kyrides assinou a patente do DOP. Durante este periodo, polímeros 
termoplásticos sintéticos entraram em produção comercial: acetato de polivinila em 1925 e acetato de celulose em 1927.

Em 1931 o PVC se tornou disponível. Sem plastificação ele apareceu como a mais descrente de todas as resinas sintéticas emergentes. Era insolúvel em solventes comuns, não podia ser moldado sem decomposição térmica. Quando aquecido, produzia irritação pela fumaça de $\mathrm{HCl}$ e tornavase preto após alguns dias de exposição a luz solar. O sucesso comercial do PVC foi garantido quando Semon descobriu que sob aquecimento o PVC dissolvia em solventes como o-nitrodifenil éter, ftalato de dibutila ou fosfato de tricresil, e após resfriamento formava um composto do tipo borracha.

A sobrevivência comercial de um plastificante depende muito do impacto nas propriedades desejadas do produto final. A história desta tecnologia é a história de técnicas de soluçōes progressivas e de problemas comerciais na direção de se fabricar produtos de excelente qualidade com preços razoáveis.

A tecnologia de plastificantes ajudou no crescimento do uso de plásticos. Plastificantes hoje são usados comercialmente em quantidades importantes, em cerca de 35 diferentes polímeros, sendo o PVC o maior mercado. $O$ uso mundial de plastificantes no início dos anos 80 foi cerca de três milhões de toneladas por ano, e $30 \%$ representa o consumo dos EUA ${ }^{(13)}$.

\subsubsection{Estabilidade da compatibilidade}

O uso de plastificantes no PVC resultou em melhoria de sua estabilidade em baixas temperaturas, diminuição da resistência à tração e redução das temperaturas de processamento e viscosidade de fusão. 
Plastificantes que têm parâmetros de solubilidade, polaridade e ligações de hidrogênio similares ao PVC são compatíveis e exibem um bom poder de solvatação. Entretanto, quando as forças de atração entre os plastificantes ou resinas são maiores para eles mesmos do que em relação um ao outro, resulta em exudação ou migração ${ }^{(10)}$.

$\mathrm{Na}$ prática, o desenvolvimento de teorias e medidas preditivas de compatibilidade foram frustradas pelas alteraçōes químicas e/ou ambientes físicos que promoveram a separação de fases, migração, ou tato pegajoso superficial. Como exemplo, a composição vinílica, o éster di-2-etilexil do anidrido maleico/isopreno preenche todos os requisitos teóricos de compatibilidade para um plastificante, pois possui uma estrutura similar ao DOP, mas contém grupos alifáticos insaturados. Uma amostra plastificada exposta ao tempo atrás de uma janela de vidro produziu uma superficie pegajosa em curto espaço de tempo. $O$ produto migrado não era o éster compatível inicial, mas um foto-oxidado, um produto mudado quimicamente que não poderia retornar a matriz vinílica. A migração foi agravada pelo tipo de estabilizante (epóxi, que é considerado o pior no processo de migração) e acelerada pela exposição à luz solar. Mesmo com o desenvolvimento de sistemas de estabilização engenhosos, nenhum foi completamente satisfatório, e, plastificantes quimicamente estáveis como ftalatos se tornaram populares.

Uma peculiaridade da estabilidade da compatibilidade do diisodecil adipato (DIDA) pode trazer problemas. Em um plastisol de PVC formulado com DIDA e fundido a $175^{\circ} \mathrm{C}$ durante 10 minutos, ocorre a migração, mas se o período de aquecimento é estendido para 30 minutos, não migra. Uma 
possível explicação seria que sob extensivo aquecimento em ar, este plastificante é suscetível à oxidação, levando a formação de peróxidos, ocorrendo a cisão da cadeia e perda de massa, o que muda a compatibilidade.

Outra fonte para problemas de migração é a incompatibilidade ao ambiente. Uma ilustração é um filme plastificado com DOP suspenso sobre um reservatório de hexano. $\mathrm{Na}$ atmosfera, a composição plastificada logo começa a aumentar em peso pela absorção do hexano pelo DOP. $O$ aumento de peso num dado nível leva ao aparecimento da migração e finalmente gotas de hexano + DOP caem do filme. DOP, que é um padrão geral de compatibilidade em compostos vinílicos, e mostra significante incompatibilidade em atmosferas particulares. Em contraste com o DOP, poliésteres não migram em atmosferas com hexano. Uma composição com DOP sujeita a vapor de água $\left(100 \%\right.$ UR a $\left.60^{\circ} \mathrm{C}\right)$ por 1 ano mostrou nenhuma migração ou apreciável mudança no peso. Mas com plastificantes poliméricos, a incompatibilidade com este ambiente ocorre. No período de 7 dias a $60^{\circ} \mathrm{C}$, uma mistura de água e plastificantes migra na superfície. Os plastificantes poliméricos absorvem água num grau até que a constante dielétrica fica longe do ótimo para compatibilidade e então migra ${ }^{(13)}$.

\subsubsection{Classificação dos plastificantes}

Plastificantes podem ser divididos em duas categorias baseados no poder de solvatação e compatibilidade. Plastificantes primários podem solvatar resinas até certos limites, retendo a compatibilidade ao longo do tempo. Plastificantes secundários têm a solubilidade e a compatibilidade 
reduzidas, e são usados somente em conjunto com plastificantes primários. A compatibilidade dos plastificantes é extensamente relatada como densidade de energia coesiva ou parâmetro de solubilidade (pode ser calculada a partir da estrutura) ${ }^{(10)}$.

Os plastificantes também são classificados pelo peso molecular; faixas menores que 500 são considerados plastificantes monoméricos e faixas de 500 a 2000 são plastificantes poliméricos. Os tipos monoméricos são mono-, di- e triésteres de ácidos ou anidridos. Plastificantes poliméricos são baseados em diácidos adípicos, azelaicos e sebácicos reagidos com dióis. A eficiência dos plastificantes poliméricos não é tão boa quanto à dos monoméricos, mas apresentam baixa volatilidade e resistência à migração. Plastificantes como óleo de soja epoxidado são intermediários no peso molecular e podem ser considerados tanto poliméricos como monoméricos $^{(10)}$.

\subsubsection{Propriedades da plastificação}

Uma propriedade valiosa dada pelo plastificante é o alongamento. A otimização desta propriedade tanto quanto as outras dependem do tempo e da temperatura de fusão adequados para a plastificação.

Plastificantes diferem significantemente em suas taxas de fusão e efeitos nas propriedades físicas. Cada sistema de plastificante para o PVC deve atingir uma temperatura mínima de especificação para alcançar a completa plastificação.

A plastificação de uma resina de PVC produz normalmente a redução do módulo, da tensão de ruptura, da dureza a baixas temperaturas enquanto 
melhora o alongamento. Entretanto, em baixas concentrações (1 a 15\%) aumentam o módulo e tensão de ruptura e diminui o alongamento. Este efeito é chamado de antiplastificação e ocorre em muitas resinas. Em polímeros amorfos, esta rigidez ocorre como resultado da perda de volume livre, pois as macromoléculas ou seus segmentos têm inicialmente liberdade em ajustar para arranjos mais compactos, algumas vezes guiados pela atração dipolar e pontes de hidrogênio, e, durante a antiplastificação ocorre uma ordem molecular suficiente que aumenta a cristalinidade, como no caso do PVC.

A maioria das melhorias de propriedades alcançadas através da plastificação é a redução significativa no Tg do PVC, assim a flexibilidade e a resistência ao impacto da composição plastificada são retidas numa faixa maior de temperatura. A diminuição de $\mathrm{Tg}$ é tão importante na teoria de volume livre que é considerado por alguns como sinônimo de plastificação. A plastificação com estruturas moleculares lineares permite a melhorar a flexibilidade em menores temperaturas e para cadeias com ramificações e anéis aromáticos mostram menor eficiência.

O índice de viscosidade de uma plastificante é o indicador da sua eficiência na flexibilidade em baixas temperaturas. Uma pequena mudança na viscosidade durante uma mudança de temperatura indica que este plastificante conferirá melhor flexibilidade em baixas temperaturas do que um plastificante que mostra uma grande mudança com a temperatura.

Antigos pesquisadores que trabalharam com formulaçōes vinílicas flexíveis estavam convencidos que a técnica de plastificação externa não era confiável devido a sua permanência inadequada na composição. 
Conseqüentemente, muitos estudos foram feitos para plastificações internas através da copolimerização. Entretanto, as resinas entäo desenvolvidas, eram geralmente incapazes de oferecer a larga faixa de propriedades e era requerida uma plastificação externa adicional.

A tecnologia de plastificação tem tido um longo caminho para superar a vulnerabilidade da composição com a perda de plastificantes. Técnicas foram desenvolvidas para garantir suficiente longevidade das propriedades essenciais nos mais agressivos ambientes para então os mercados expandirem. Perda de volatilidade de compostos vinílicos é diretamente relacionada à pressão de vapor do plastificante e resistência de oxidação. Estes são dependentes do peso molecular e estrutura. Retenção da propriedade de alongamento durante longos prazos e a exposição a altas temperaturas são fatores chaves para várias aplicações.

\subsection{MODIFICADORES DE IMPACTO}

Estes materiais são geralmente usados para proteger PVC rígidos de frágeis fraturas, como exemplo borrachas nitrílicas. São utilizados na faixa de 5 a 15 PHR. Podem ser considerados como uma fase dispersa da borracha no PVC, atuando como um desacelerador na propagação de quebras, pois pode ser deformado e dissipar a energia do impacto. A eficiência da dispersão do modificador, o qual depende da intensidade e tempo de processamento, tem efeito marcante na força de impacto.

Apresentam as desvantagens de possuir um alto custo, redução da resistência a elementos químicos, solventes e água, reduçăo da resistência à 
tração e flexão, impacto na estabilidade a UV e redução de distorçōes de temperatura ${ }^{(10)}$.

\subsection{CARGAS}

Mesmo sendo utilizadas com o objetivo de reduzir custos primeiramente, as cargas apresentam várias vantagens, como opacidade, melhoria das propriedades elétricas, resistência à luz UV, melhoria do processo de secagem do composto, melhoria da dureza, redução à tendência de migração durante o processo ("plate-out") e resistência à deformação sob elevadas temperaturas. As desvantagens podem ser descritas como as diminuições das propriedades físicas e químicas, forças de tração, grau de alongamento, performance em baixas temperaturas, resistência à abrasão e resistência ao ataque de água e químicos.

Cargas inorgânicas são uma importante classe de cargas na indústria dos plásticos e vários tipos são comercialmente usados para modificar as propriedades dos compostos plásticos. As cargas inorgânicas podem ser carbonato de cálcio, talco, sulfato de bário, pós-finos de alguns metais, triidrato de alumínio, hidrato de alumínio, etc. Estas cargas possuem algumas limitações de uso devido a maior valor de gravidade específica e menor compatibilidade com os polímeros.

Estudos estão sendo realizados com cargas orgânicas, que são caracterizadas por sua baixa gravidade específica. As cargas orgânicas podem ser resíduos de sementes, pó de casca de coco, pó de casca de ovo, resíduo de chá, etc. Algumas conclusões destes estudos apontam que a 
combinação de cargas orgânicas com inorgânicas apresentam boas propriedades mecânicas, baixa absorção de água, e baixa gravidade especifica, alguns materiais podem substituir completamente as cargas inorgânicas apresentando melhores propriedades, e, alguns materiais tem boa processabilidade ${ }^{(7)}$.

\subsection{PIGMENTOS}

Muitas das aplicações do PVC requerem o uso de pigmentos por razões estéticas e/ou para melhorar sua estabilidade à radiação UV, melhorando assim sua resistência ao intemperismo. $O$ efeito dos pigmentos nas propriedades físicas dos compostos de PVC é pouco significativo, pois são utilizados em pequenas quantidades.

Pigmentos e corantes são distintos primariamente pela solubilidade no meio de aplicação, pigmentos são insolúveis no polímero, enquanto os corantes são completamente solubilizados no polímero fundido. Os pigmentos podem ser utilizados em diferentes formas, sendo a forma mais comum o pó fino e seco. Também podem ser incorporados à formulação na forma de mistura seca, pasta, líquido ou "masterbatch" (dispersões de pigmentos ou corantes em resina de PVC/aditivos, na forma granulada) ${ }^{(12)}$.

Muitos polímeros em seu estado puro são bons isolantes elétricos, entretanto, em alguns casos, existe uma demanda para polímeros condutivos ou semi-condutivos. Alguns materiais como o negro de fumo, grafite, pós e óxidos metálicos são cargas condutivas eletricamente, e podem ser utilizadas para esta finalidade. Porém, quando o uso é apenas para coloração em 
polímeros com aplicação para isolação elétrica, a recomendação para o conteúdo deste material é que seja reduzido o quanto for possivel, pois pode proporcionar graus de condutividade elétrica ${ }^{(1)}$.

\subsection{OUTROS ADITIVOS}

- Estabilizantes térmicos: A necessidade de se usar faixas de temperaturas estreitas e reduzir o tempo de processamento em temperaturas mais elevadas para prevenir a degradação térmica foi a bandeira das fábricas de produtos vinílicos até a metade do século passado ${ }^{(13)}$. Assim, o grande crescimento dos plásticos vinílicos se deu também pelo desenvolvimento de estabilizantes térmicos mais eficientes. Quando o PVC é exposto em certas condições de calor e luz, o $\mathrm{HCl}$ é desprendido e resulta uma estrutura de polieno conjugado. A degradação começa em torno de $93^{\circ} \mathrm{C}$ e aumenta com o tempo e temperatura. Com o avanço da degradação, a cor do plástico muda de branco (ou transparente) para amarelo até chegar no marrom e finalmente preto. A formação da cor geralmente precede uma severa deterioração das propriedades físicas do polímero. Um requisito para um bom estabilizante é a sua habilidade em prevenir a descoloração durante a produção de compostos de PVC. Acredita-se que o estabilizante reage com o $\mathrm{HCl}$ liberado e reduz a taxa de degradação. A liberação do $\mathrm{HCl}$ é em função do tempo, temperatura e ambiente. Uma grande variedade de composiçōes é oferecida comercialmente para o PVC, podendo ser compostos de chumbo, metálicos, orgânicos auxiliares, organotins, de antimônio, etc. Geralmente são usados nas faixas de 1 a 8 PHR. A maioria é 
combinações de dois ou mais ingredientes ativos que atuam em cooperação. A seleção do estabilizante deve considerar o tipo de resina, exposição a elementos, alto cisalhamento, condições de altas temperaturas de processo e propriedades elétricas. Não pode ser esperada uma ação por tempo indefinido. Eles servem para retardar a degradação nos períodos críticos de processamento e estender para a vida útil do produto final ${ }^{(10)}$.

- Aditivos de processo: O processamento do PVC rígido com alto peso molecular é extremamente difícil. Embora homopolímeros de baixo peso molecular ou resinas de copolímeros possam ser processados com menor dificuldade, a estabilidade térmica e as propriedades físicas são inferiores do que em resinas com alto peso molecular. Aditivos de processo ou lubrificantes são incorporados nestas resinas para alcançar a eficiência do processamento, com a vantagem de melhor estabilidade térmica e maiores distorções de temperatura. Eles aumentam as taxas de processamento, permitem menores temperaturas de processo, promovem fusão, influenciam na maciez, reduzem o brilho superficial, melhoram o desprendimento dos rolos no processo de calandragem, reduzem "plate-out", aumentam a resistência ao atrito e melhoram a conformação. Se forem usados em porcentagens maiores que $10 \mathrm{PHR}$, têm como desvantagens a redução à resistência a químicos e solventes, podem afetar a resistência ao envelhecimento e luz UV e a redução da força de impacto ${ }^{(10)}$.

- Retardante de chama: devido ao PVC conter alto teor de cloro, é inerente ao polímero queimar com extrema dificuldade ou ser autoextinguível. Entretanto, quando mais de 25 PHR de um plastificante inflamável é adicionado, a composição queimará. A combustão do PVC 
plastificado é dependente do tipo e concentração do presente plastificante. No final da década de 50, a flamabilidade de muitos sistemas poliméricos começou a receber atenção de uma variedade de agências e organizações. Certos ésteres de fosfatos podem ser usados na faixa de 10 a 20 PHR para fornecer uma composição retardante de chama. O óxido de antimônio é utilizado na faixa de 1 a 3 PHR. O mecanismo de queima de polímeros pode ser através da pirólise térmica do plástico, produzindo gases que agem como combustivel para o fogo. Os retardantes de chama trabalham tanto na fase condensada e vapor para interromper a fusão do polímero e queimam os gases $^{(10,13)}$

- Antioxidantes: certos componentes dos estabilizantes térmicos servem como antioxidantes (por exemplo, fosfitos). Compostos de PVC podem requerer proteção em serviços em altas temperaturas, como em um cabo de isolamento elétrico. O bisfenol $A$ é freqüentemente incorporado em plastificantes com este propósito. Modificadores de impacto contém insaturações e requerem proteções antioxidantes.

- Estabilizantes de luz: a exposição do PVC à luz do Sol resulta em degradação devido ao efeito da luz UV. A primeira indicação de degradação é a descoloração seguida da perda de propriedades físicas, como a perda de tensão de ruptura e fragilidade. Estabilizantes UV absorvem a luz UV e a energia absorvida é dissipada como calor. O uso de pigmentos como dióxido de titânio ou negro de fumo em conjunto com plastificantes epoxidados e fosfitos resulta na melhoria da estabilidade à luz. São utilizados na faixa de 0,2 a 0,5 PHR. 
- Fungicidas: apesar do PVC ser resistente a deterioração microbiológica, outros compostos como plastificantes e lubrificantes são atacados por fungos, bactérias e outros microorganismos. Este ataque pode resultar em desenvolvimento de cor até degradações mais sérias, causando perda da resistência à tração e alongamento, propriedades elétricas, migração e odor.

\subsection{DEGRADAÇÃO TÉRMICA DO PVC}

Os principais fatores de influência na degradação de materiais de PVC incluem oxigênio, umidade, "stress" mecânico, meio agressivo, radiação ionizante, e todos estes fatores são acelerados pelo aumento de temperatura. A degradação leva a mudanças nas propriedades devido a um processo químico e físico simultâneo, causando mudanças na composição química e estrutura de materiais ${ }^{(2)}$.

PVC é um dos polímeros mais usados em blendas com outros polimeros, o que resulta em ligas heterogêneas que afetam a estabilidade térmica do PVC. Para propósitos industriais, a descoloração do PVC é a mais usada para determinar a degradação térmica, mas não pode ser aplicada para blendas, pois alguns polímeros também descolorem com a degradação (por exemplo, polibutadieno (PB) e poliacrilonitrila (PAN)). Métodos termogravimétricos também são utilizados para as blendas; os componentes voláteis são determinados por espectroscopia, mas tem a desvantagem da baixa acuracidade para as baixas conversões de $\mathrm{HCl}$. 
Melhores resultados foram obtidos pela determinação do $\mathrm{HCl}$ por condutividade ou $\mathrm{pH}$, mas gera resultados errados quando algum componente da blenda reage com $\mathrm{HCl}$. A degradação térmica tem sido estudada por DSC, que indica o aumento da Tg do PVC devido às ligações cruzadas das cadeias durante a degradação. Desde que a ligação cruzada está diretamente ligada às propriedades mecânicas do PVC, O aumento de Tg pode ser usado para estudar a influência do segundo polímero na degradação do PVC em blendas heterogêneas.

Estudos de degradação térmica de blendas com poliestireno (PS), polistireno acrilonitrila (SAN), poliestireno butadieno de alto impacto (HIPS) e polistireno acrilonitrila butadieno (ABS) foram feitos usando a técnica de DSC. A análise de amostras com e sem estabilizante térmico mostrou que a taxa de degradação do PVC com estabilizante é menor do que sem estabilizante. Nas blendas com SAN e ABS, estes compostos afetam a estabilização térmica do PVC, pois os grupos nitrilas podem acelerar a degradação ou pode ocorrer à evolução de produtos voláteis do copolímero, modificando os resultados. $\mathrm{A}$ análise de $\mathrm{Tg}$ e medidas de condutividade elétrica da blenda com PS mostraram alta estabilidade térmica devido à fase borracha do PS ${ }^{(14)}$. 


\subsection{MATERIAIS}

Os materiais que foram utilizados neste trabalho foram escolhidos baseados em produtos já comercializados para facilitar o emprego destes em futuras aplicações industriais.

\subsubsection{PVC}

Foi utilizado o policloreto de vinila, homopolímero, obtido pelo processo de polimerização em suspensão.

Características gerais:

- Valor K (parâmetro de peso molecular) - 71

- Materiais voláteis $-0,3 \%$

- Granulometria $>250 \mu \mathrm{m}-1 \%$

- Granulometria $<63 \mu \mathrm{m}-5 \%$

- Densidade volumétrica $-0,47 \mathrm{~g} / \mathrm{cm}^{3}$

\subsubsection{Plastificantes}

Para a preparação dos materiais empregados no estudo realizado neste trabalho foi utilizada a mistura de três plastificantes: a) um plastificante 
polimérico de médio peso molecular, resultante da reação de poliésteres e glicóis, b) um plastificante monomérico e c) um plastificante secundário.

a) Características gerais do plastificante polimérico:

- Umidade - 0,1\%

- Indice de acidez - 1,0 mgKOH/g

- Viscosidade $-2100 \mathrm{cps}$

- Densidade - 1,10 $\mathrm{g} / \mathrm{cm}^{3}$

- Ponto de fusão - abaixo de $0^{\circ} \mathrm{C}$

- Insolúvel em água

b) Caracteristicas gerais do plastificante monomérico:

- Umidade - 0,1\%

- Índice de acidez - 0,1 mgKOH/g

- Densidade - 0,982 $\mathrm{g} / \mathrm{cm}^{3}$

- Teor de éster - 99\%

- Ponto de fulgor $-200^{\circ} \mathrm{C}$

c) Características gerais do plastificante secundário:

- Índice de acidez - 0,7 mgKOH/g

- Viscosidade $-380 \mathrm{cps}$

- Densidade - 0,990 g/cm

- Voláteis $-0,20 \%$

- Ponto de fulgor $-280^{\circ} \mathrm{C}$ 


\subsubsection{Modificador de impacto}

Foi utilizada a borracha nítrica como modificador de impacto.

Características gerais:

- Umidade $-0,7 \%$

- Granulometria - $1,0 \%$

- Agente de partição - 10 pcp

- Viscosidade Mooney $-47 \mathrm{mml}$

\subsubsection{Carga}

Foi utilizado o silicato de alumínio como carga, com pó de diâmetro médio de $2 \mu \mathrm{m}$.

Características gerais:

- Umidade $-0,5 \%$

- Granulometria, malha $325-0,01 \%$

- $\mathrm{pH}-5,5$

- Insolubilidade em $\mathrm{HCl} 60 \%$

\subsubsection{Pigmento}

Foi utilizado o negro de fumo como pigmento orgânico.

Características gerais:

- Umidade $-2,5 \%$

- Poder de tingimento $-103 \mathrm{~m}^{2} / \mathrm{g}$

- Granulometria, malha $35-5$ ppm

- Granulometria, malha $325-700$ ppm 
- Teor de cinzas $-0,75 \%$

\subsubsection{Outros Aditivos}

\subsubsection{Estabilizante térmico}

Características gerais do fosfito de chumbo:

- Umidade - 0,3\%

- Granulometria, malha $325-0,10 \%$

- Teor de chumbo - $90 \%$

- Densidade $-6,8 \mathrm{~g} / \mathrm{cm}^{3}$

\subsubsection{Lubrificante}

Características gerais do estearato de cálcio:

- Umidade - $4 \%$

- Ponto de fusão $-145^{\circ} \mathrm{C}$

- Granulometria, malha $325-96 \%$

- Cinzas $-16 \%$

\subsubsection{Retardante de chama}

Características gerais do trióxido de antimônio:

- Umidade $-0,1 \%$

- Granulometria, malha $325-0,01 \%$

- Tamanho médio de partícula - 1,45 $\mu \mathrm{m}$ 


\subsubsection{Formulação das amostras}

No presente estudo várias formulações foram obtidas pela mistura de componentes na proporção mostrada nas Tabelas de I a V. As formulações foram identificadas como Referência e Amostra 1 até Amostra 4, com 6 subgrupos. Nas tabelas, as linhas marcadas em cinza indicam a parte da composição que foi variada no conjunto de amostras.

Tabela I - Formulação referencial (PHR) - tipo Amostra Referência.

\begin{tabular}{|l|c|}
\hline \multicolumn{1}{|c|}{ Materiais } & Referência \\
\hline Resina PVC & 100,0 \\
\hline Aditivos & 5,1 \\
\hline Estabilizante térmico & 4,0 \\
\hline Plastificantes & 50,0 \\
\hline Carga & 15,0 \\
\hline Pigmento & 1,0 \\
\hline Modificador de impacto & 5,8 \\
\hline
\end{tabular}

Tabela II - Composição da formulação tipo Amostra 1 - Variação do pigmento (PHR).

\begin{tabular}{|l|c|c|c|c|c|c|}
\hline \multicolumn{1}{|c|}{ Materiais } & $\begin{array}{c}\text { Amostra } \\
\mathbf{1 . 1}\end{array}$ & $\begin{array}{c}\text { Amostra } \\
\mathbf{1 . 2}\end{array}$ & $\begin{array}{c}\text { Amostra } \\
\mathbf{1 . 3}\end{array}$ & $\begin{array}{c}\text { Amostra } \\
\mathbf{1 . 4}\end{array}$ & $\begin{array}{c}\text { Amostra } \\
\mathbf{1 . 5}\end{array}$ & $\begin{array}{c}\text { Amostra } \\
\mathbf{1 . 6}\end{array}$ \\
\hline Resina PVC & 100,0 & $\mathbf{1 0 0 , 0}$ & 100,0 & 100,0 & 100,0 & 100,0 \\
\hline Aditivos & 5,1 & $\mathbf{5 , 1}$ & 5,1 & 5,1 & 5,1 & 5,1 \\
\hline Estabilizante térmico & 4,0 & $\mathbf{4 , 0}$ & 4,0 & 4,0 & 4,0 & 4,0 \\
\hline Plastificantes & 50,0 & $\mathbf{5 0 , 0}$ & 50,0 & 50,0 & 50,0 & 50,0 \\
\hline Carga & 15,0 & $\mathbf{1 5 , 0}$ & 15,0 & 15,0 & 15,0 & 15,0 \\
\hline Pigmento & 0,0 & $\mathbf{0 , 4}$ & 0,8 & 1,2 & 1,6 & 2,0 \\
\hline Modificador impacto & 5,8 & $\mathbf{5 , 8}$ & 5,8 & 5,8 & 5,8 & 5,8 \\
\hline
\end{tabular}


Tabela III - Composição da formulação tipo Amostra 2 - Variação da carga (PHR).

\begin{tabular}{|l|c|c|c|c|c|c|}
\hline \multicolumn{1}{|c|}{ Materiais } & $\begin{array}{c}\text { Amostra } \\
\mathbf{2 . 1}\end{array}$ & $\begin{array}{c}\text { Amostra } \\
\mathbf{2 . 2}\end{array}$ & $\begin{array}{c}\text { Amostra } \\
\mathbf{2 . 3}\end{array}$ & $\begin{array}{c}\text { Amostra } \\
\mathbf{2 . 4}\end{array}$ & $\begin{array}{c}\text { Amostra } \\
\mathbf{2 . 5}\end{array}$ & $\begin{array}{c}\text { Amostra } \\
\mathbf{2 . 6}\end{array}$ \\
\hline Resina PVC & 100,0 & 100,0 & 100,0 & 100,0 & 100,0 & 100,0 \\
\hline Aditivos & 5,1 & 5,1 & 5,1 & 5,1 & 5,1 & 5,1 \\
\hline Estabilizante térmico & 4,0 & 4,0 & 4,0 & 4,0 & 4,0 & 4,0 \\
\hline Plastificantes & 50,0 & 50,0 & 50,0 & 50,0 & 50,0 & 50,0 \\
\hline Carga & 0,0 & 6,0 & 12,0 & 18,0 & 24,0 & 30,0 \\
\hline Pigmento & 1,0 & 1,0 & 1,0 & 1,0 & 1,0 & 1,0 \\
\hline Modificador impacto & 5,8 & 5,8 & 5,8 & 5,8 & 5,8 & 5,8 \\
\hline
\end{tabular}

Tabela IV - Composição da formulação tipo Amostra 3 - Variação do modificador de impacto (PHR).

\begin{tabular}{|l|c|c|c|c|c|c|}
\hline \multicolumn{1}{|c|}{ Materiais } & $\begin{array}{c}\text { Amostra } \\
3.1\end{array}$ & $\begin{array}{c}\text { Amostra } \\
3.2\end{array}$ & $\begin{array}{c}\text { Amostra } \\
3.3\end{array}$ & $\begin{array}{c}\text { Amostra } \\
3.4\end{array}$ & $\begin{array}{c}\text { Amostra } \\
3.5\end{array}$ & $\begin{array}{c}\text { Amostra } \\
3.6\end{array}$ \\
\hline Resina PVC & 100,0 & 100,0 & 100,0 & 100,0 & 100,0 & 100,0 \\
\hline Aditivos & 5,1 & 5,1 & 5,1 & 5,1 & 5,1 & 5,1 \\
\hline Estabilizante térmico & 4,0 & 4,0 & 4,0 & 4,0 & 4,0 & 4,0 \\
\hline Plastificantes & 50,0 & 50,0 & 50,0 & 50,0 & 50,0 & 50,0 \\
\hline Carga & 15,0 & 15,0 & 15,0 & 15,0 & 15,0 & 15,0 \\
\hline Pigmento & 1,0 & 1,0 & 1,0 & 1,0 & 1,0 & 1,0 \\
\hline Modificador impacto & 0,0 & 2,4 & 4,8 & 7,2 & 9,6 & 12,0 \\
\hline
\end{tabular}

Tabela V - Composição da formulação tipo Amostra 4 - Variação dos plastificantes (PHR).

\begin{tabular}{|l|c|c|c|c|c|c|}
\hline \multicolumn{1}{|c|}{ Materiais } & $\begin{array}{c}\text { Amostra } \\
4.1\end{array}$ & $\begin{array}{c}\text { Amostra } \\
4.2\end{array}$ & $\begin{array}{c}\text { Amostra } \\
4.3\end{array}$ & $\begin{array}{c}\text { Amostra } \\
4.4\end{array}$ & $\begin{array}{c}\text { Amostra } \\
4.5\end{array}$ & $\begin{array}{c}\text { Amostra } \\
4.6\end{array}$ \\
\hline Resina PVC & 100,0 & 100,0 & 100,0 & 100,0 & 100,0 & 100,0 \\
\hline Aditivos & 5,1 & 5,1 & 5,1 & 5,1 & 5,1 & 5,1 \\
\hline Estabilizante térmico & 4,0 & 4,0 & 4,0 & 4,0 & 4,0 & 4,0 \\
\hline Plastificantes & 0,0 & 12,0 & 24,0 & 36,0 & 48,0 & 60,0 \\
\hline Carga & 15,0 & 15,0 & 15,0 & 15,0 & 15,0 & 15,0 \\
\hline Pigmento & 1,0 & 1,0 & 1,0 & 1,0 & 1,0 & 1,0 \\
\hline Modificador impacto & 5,8 & 5,8 & 5,8 & 5,8 & 5,8 & 5,8 \\
\hline
\end{tabular}




\subsubsection{Preparação das amostras}

$\mathrm{Na}$ preparação das amostras utilizou-se o procedimento usado pelo Laboratório Técnico de Produtos Elétricos da empresa 3M do Brasil, conforme Figura 3, produzindo a quantidade de $2,5 \mathrm{Kg}$ de mistura para cada formulação. As massas dos materiais foram pesadas numa balança MettlaToledo, com precisão de $0,01 \mathrm{~g}$.

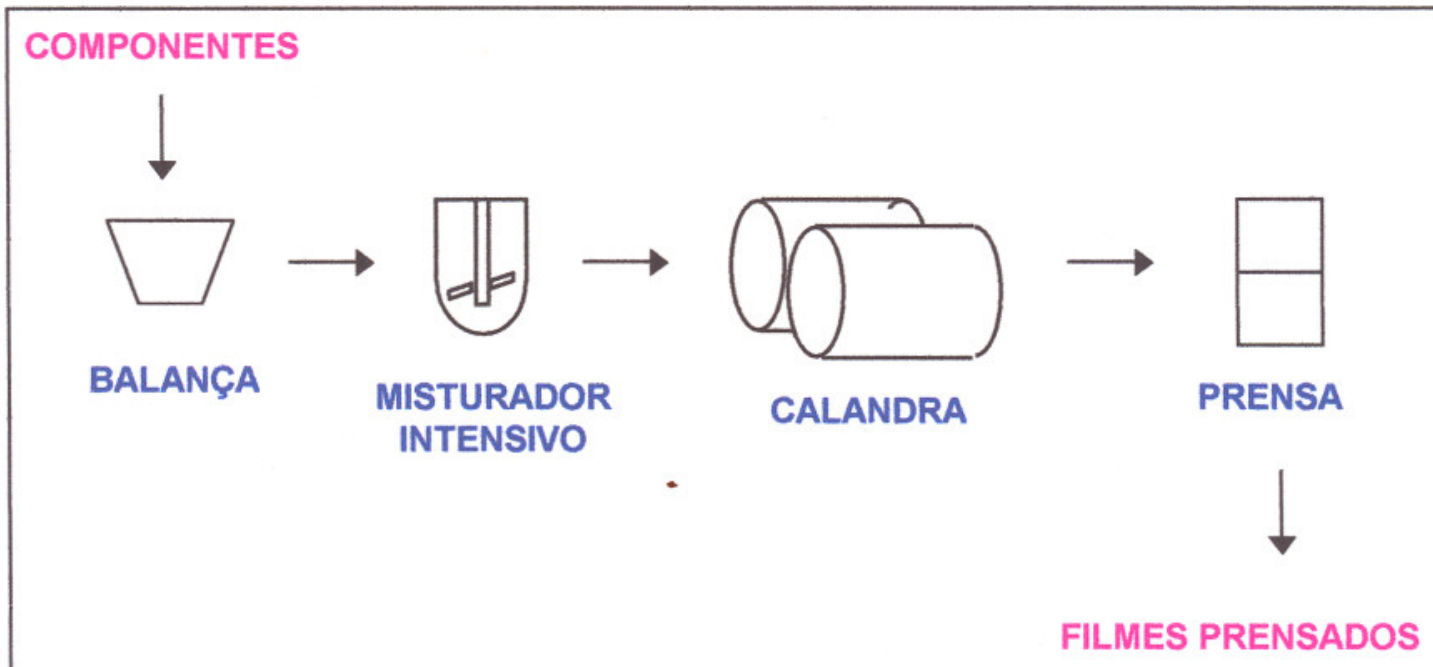

Figura 3 - Fluxograma de preparação de amostras.

As formulações foram preparadas usando um misturador intensivo Mecanoplast, com dois estágios de velocidade, mostrado na Figura 4. Primeiro misturou-se a resina de PVC e o estabilizante térmico, sob agitação rápida durante 3 minutos. Após este período adicionaram-se os plastificantes (previamente misturados) sob agitação mais lenta e misturou-se durante 4 minutos. Os outros aditivos, com exceção do pigmento, foram adicionados na velocidade mais rápida e prosseguiu-se a mistura até a temperatura do material atingir $105{ }^{\circ} \mathrm{C}$ (medida através de "heat tracer"). O material foi descarregado do equipamento e foi resfriado a temperatura ambiente. Para 
as formulações que continham pigmento este foi adicionado após o resfriamento do material.

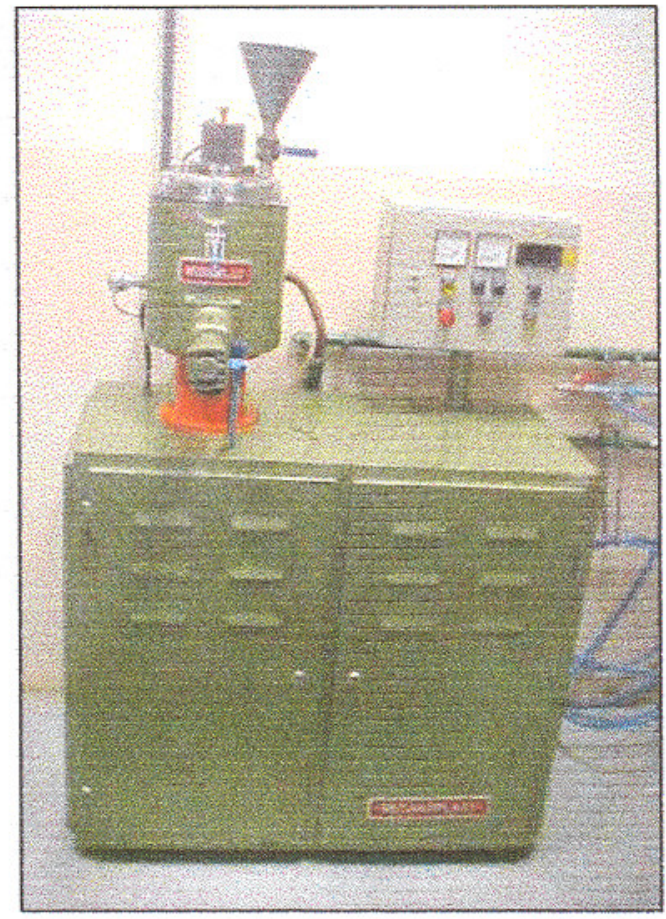

Figura 4 - Foto do misturador intenșivo Mecanoplast.

A fusão do material foi feita numa calandra de dois rolos, com temperatura controlada, mostrada na Figura 5. Utilizou-se as temperaturas dos cilindros traseiro e dianteiro na faixa de $175^{\circ} \mathrm{C}$ a $180^{\circ} \mathrm{C}$. A mistura foi feita em velocidade baixa (cilindros) durante 3 minutos. 


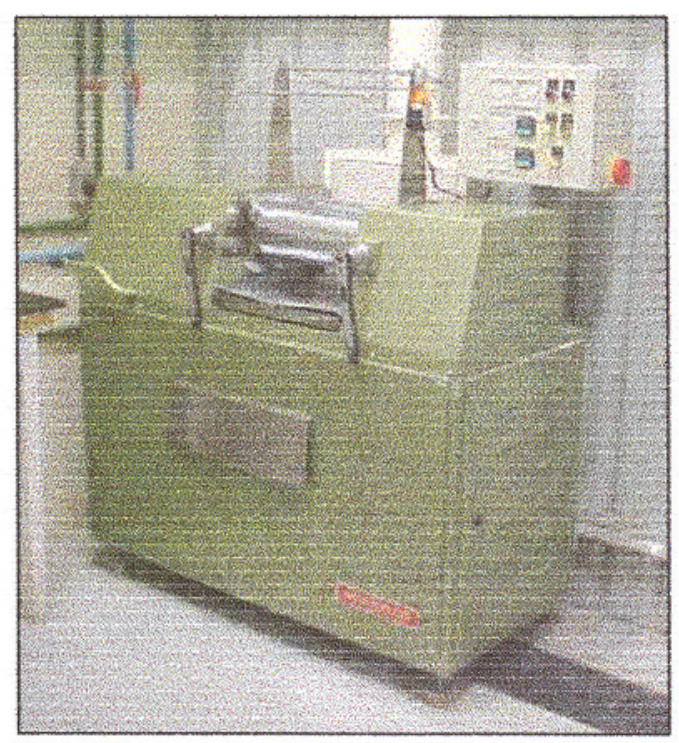

Figura 5 - Foto da calandra de dois rolos.

A obtenção das amostras foi feita através de uma prensa automática de quatro placas com sistema de aquecimento e resfriamento, mostrada na Figura 6. A temperatura de prensagem foi $190^{\circ} \mathrm{C}$ e para o resfriamento a temperatura foi $50^{\circ} \mathrm{C}$, obtendo-se placas de aproximadamente $1 \mathrm{~mm}$ de espessura, a partir de uma forma com esta espessura.

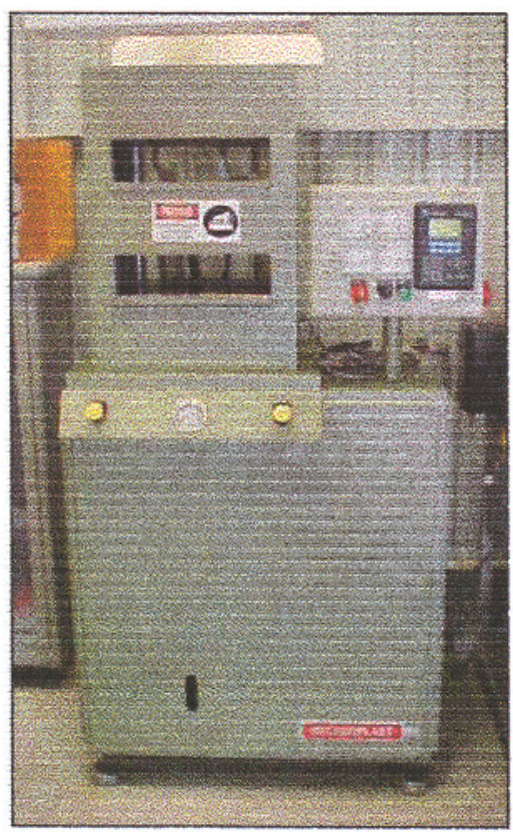

Figura 6 - Foto da prensa automática. 
Os corpos de prova foram obtidos a partir das placas prensadas, de acordo com a necessidade de cada medida, utilizando-se os padröes dimensionais exigidos em cada tipo de medida.

\subsection{MÉTODOS}

\subsubsection{Medidas Térmicas}

\subsubsection{Calorimetria exploratória diferencial (DSC)}

DSC é uma técnica de caracterização de materiais em que é medida a diferença de fluxo de calor de uma amostra a ser estudada ( 5 a $15 \mathrm{mg}$ ) e de um material de referência, enquanto ambos são submetidos a um aquecimento ou resfriamento controlado. A temperatura e a diferença de fluxo de calor são representadas em um gráfico $X-Y$, e a área sob a curva resultante é a medida direta do calor de transição. Uma das principais aplicações de DSC é na análise de transformações de fase de primeira ou segunda ordem em polímeros ${ }^{(15)}$.

As medidas de DSC foram realizadas em um equipamento da Netzsch, modelo DSC 204, conforme mostrado na Figura 7. Todas as medidas foram realizadas de -120 até $400^{\circ} \mathrm{C}$, com taxa de aquecimento de $10^{\circ} \mathrm{C} / \mathrm{min}$, utilizando-se nitrogênio como gás de arraste. 


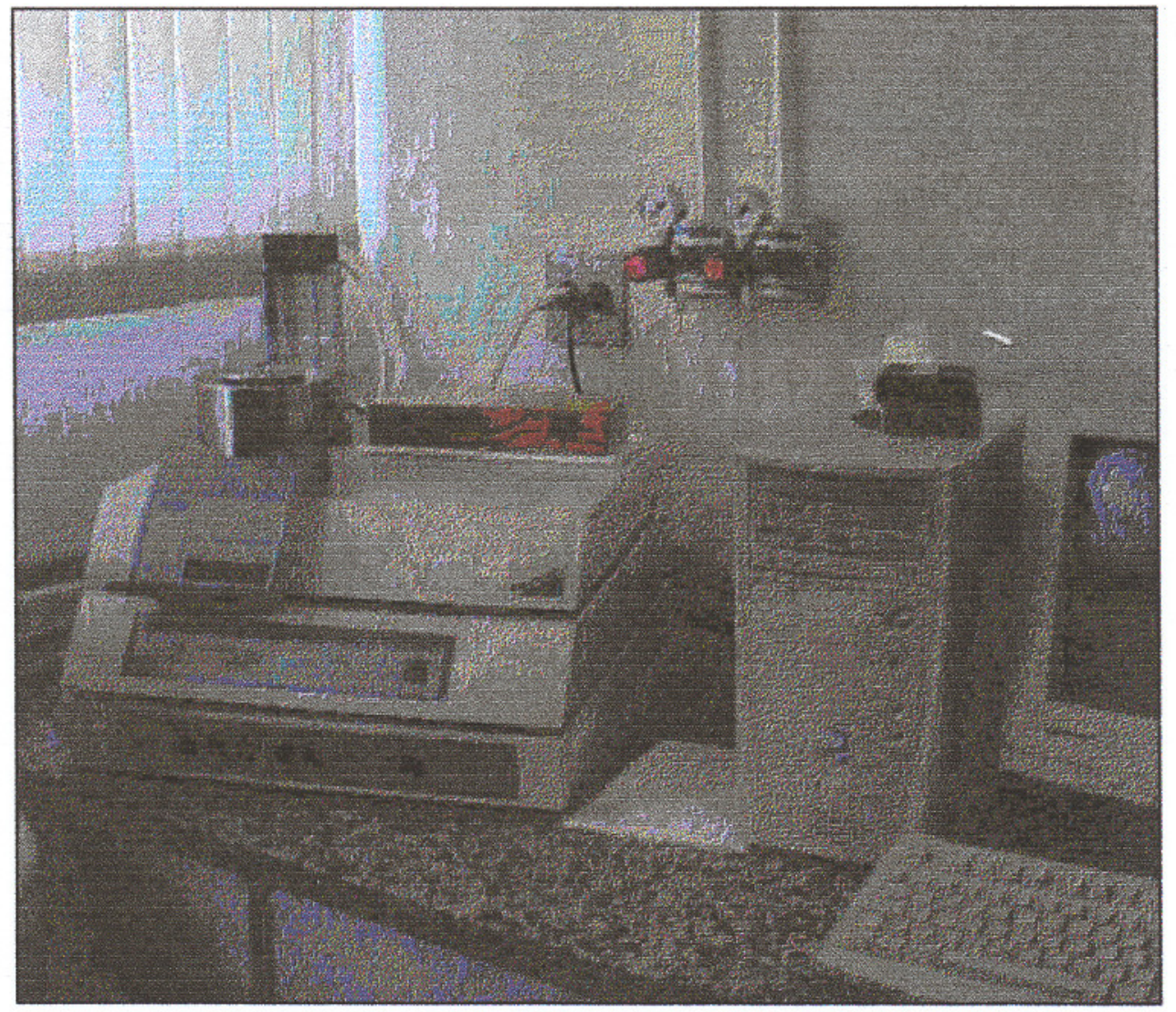

Figura 7 - Foto do equipamento de DSC

\subsubsection{Análise dinâmico-mecânica (DMA)}

A análise DMA é um método termoanalítico no qual o comportamento mecânico de uma amostra é investigado sob o efeito de um esforço mecânico que oscila no tempo. A determinação do módulo de armazenamento e de perda e o fator "amortecimento" de uma amostra são feitos em função da temperatura, tempo e da freqüência do esforço mecânico oscilatório ${ }^{(15)}$.

As medidas de DMA foram realizadas em um equipamento Netzsch modelo DMA 242 C, conforme mostrado na Figura 8. As análises foram 
realizadas com uma faixa de temperatura de -120 até $200{ }^{\circ} \mathrm{C}$, com taxa de aquecimento de $5^{\circ} \mathrm{C} /$ min e uma freqüência de excitação mecânica de $1 \mathrm{~Hz}$.

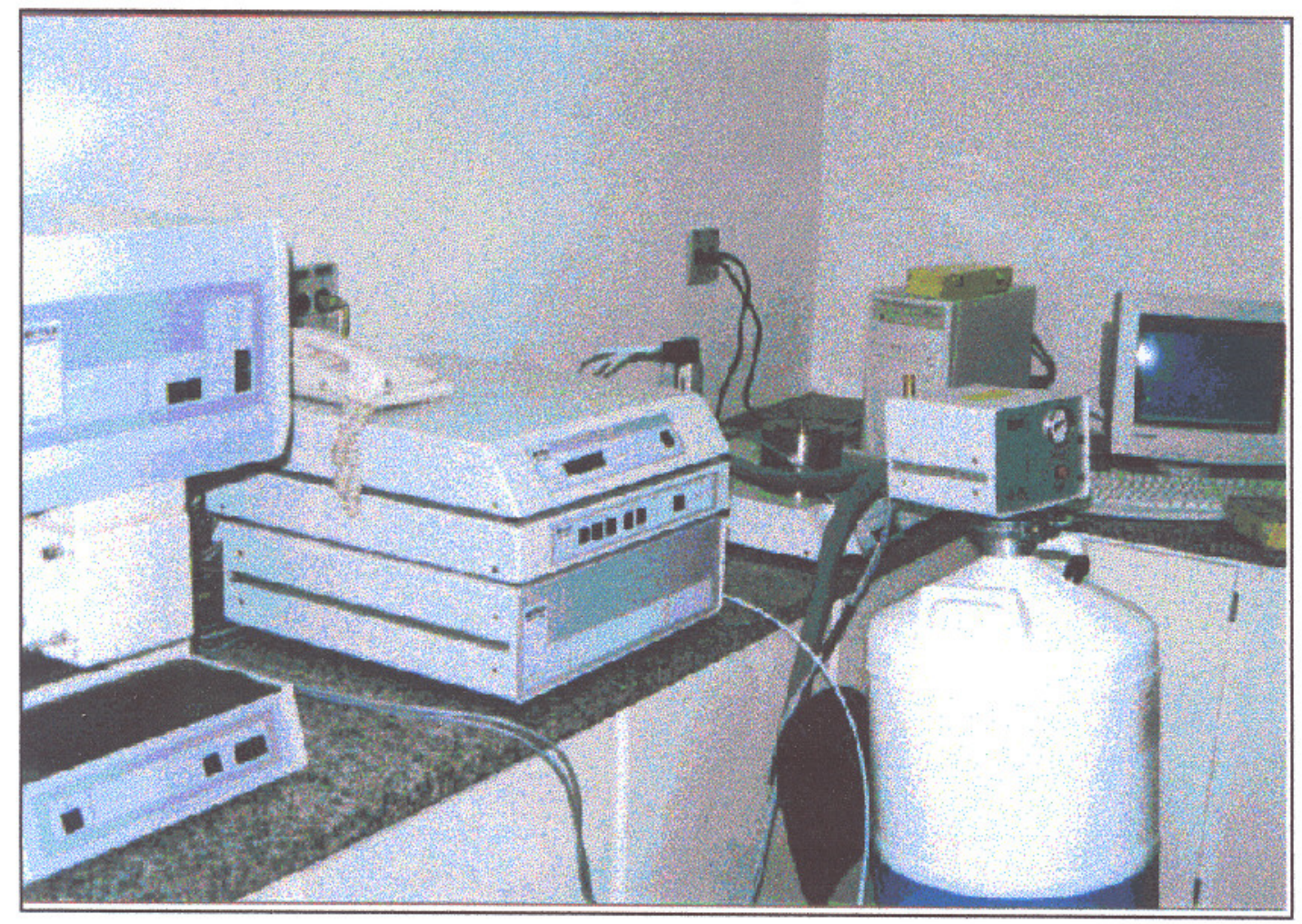

Figura 8 - Foto do equipamento de DMA

\subsubsection{Análise termogravimétrica (TGA)}

Termogravimetria é o processo no qual são medidas as variações de massa de uma amostra em função da temperatura ou tempo.

As medidas de TGA foram realizadas em um equipamento da Netzsch modelo TG 209, conforme mostrado na Figura 9, com uma varredura de aquecimento da temperatura ambiente até $700^{\circ} \mathrm{C} \mathrm{com}$ taxa de aquecimento de $10^{\circ} \mathrm{C} / \mathrm{min}$. 


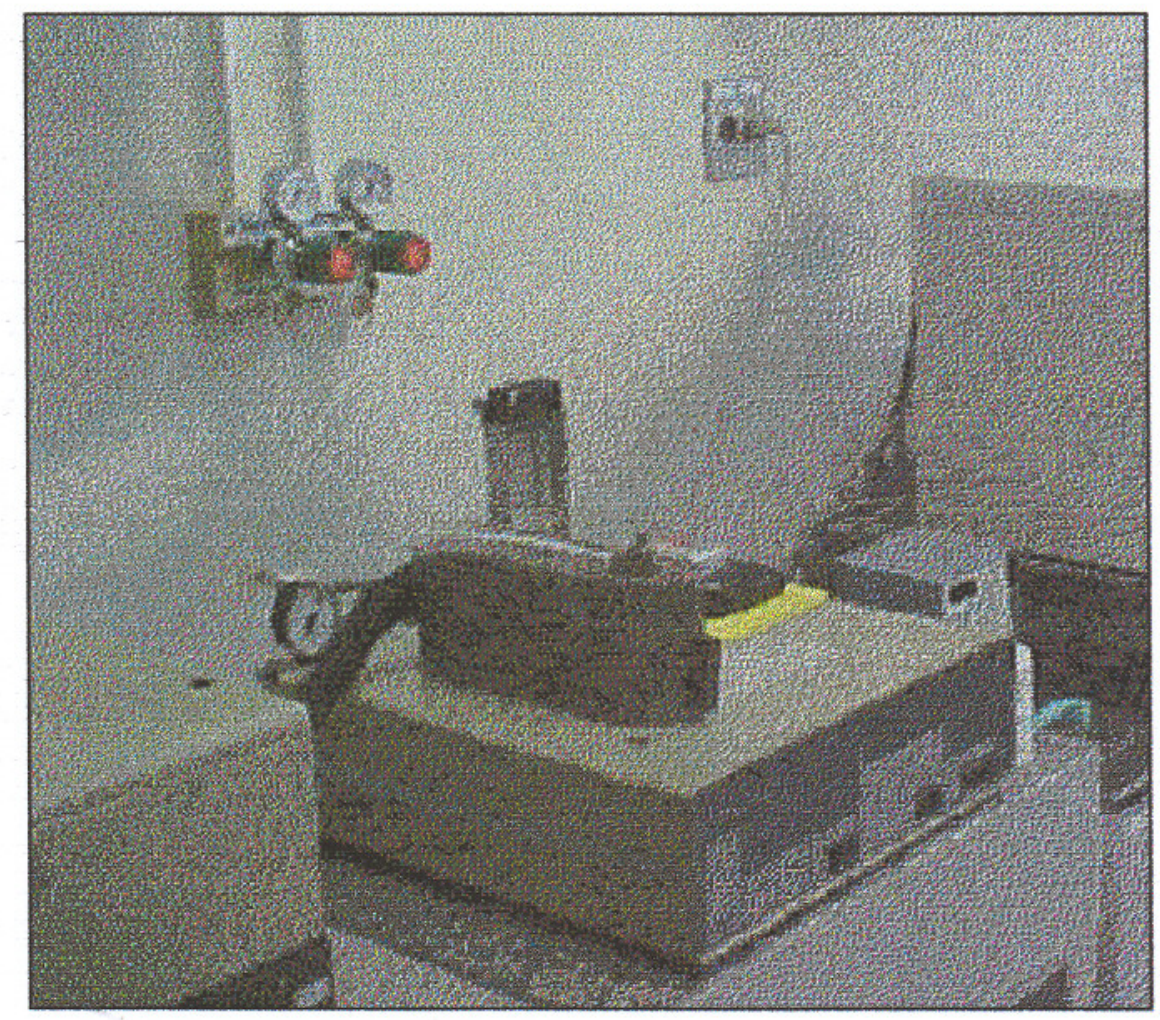

Figura 9 - Foto do equipamento de TGA

\subsubsection{Medidas Mecânicas}

\subsubsection{Resistência à tração e alongamento}

Foi utilizada a máquina de ensaio de tração Kratos, modelo K2.000 MP, software Tracomp W95, mostrada na Figura 10. Os parâmetros usados no equipamento para a realização das medidas foram baseados na Norma NBR 5037IASTM ${ }^{(16)}$ para filmes de PVC, que podem ser encontrados no Anexo A. A velocidade de ensaio foi $300 \mathrm{~mm} / \mathrm{min}$ e a abertura inicial entre as garras foi de $50 \mathrm{~mm}$. 


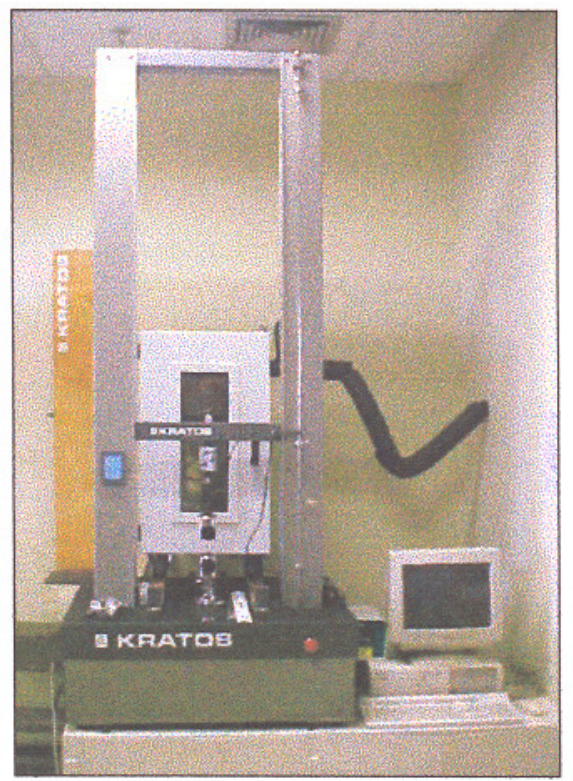

Figura 10 - Foto da máquina de ensaio de tração Kratos.

A partir dos filmes prensados foram cortados os corpos de prova com $10 \mathrm{~mm}$ de largura e aproximadamente $150 \mathrm{~mm}$ de comprimento. Estas amostras foram condicionadas durante 24 horas em temperatura e umidade controladas $\left(21^{\circ} \mathrm{C}\right.$ a $25^{\circ} \mathrm{C}, 45$ a 55 UR) antes da realização dos ensaios. Durante os ensaios foram lidas a temperatura e umidade da sala de testes e mediu-se a espessura de cada amostra empregando-se um micrômetro com precisão de 0,001 $\mathrm{mm}$.

A leitura da resistência à tração e porcentagem de alongamento foi feito no rompimento da amostra, sendo o resultado obtido expresso pela média de 3 amostras para cada formulação. $O$ valor da resistência à tração (ou tensão de ruptura) e a porcentagem de alongamento são dados pelas seguintes fórmulas:

Resistênci a à ruptura $=\frac{\text { Força Máxima }}{(\text { Espessura } \times \text { Largura })_{\text {corpo de prove }}}$ 
$\%$ Alongamento $=\frac{(\text { Abertura final }- \text { Abertura inicial })}{\text { Abertura inicial }} \times 100$

\subsubsection{Medidas Elétricas}

\subsubsection{Rigidez Dielétrica}

Este método descreve 0 procedimento de obtenção da medida de rigidez dielétrica de um material isolante sob a tensão elétrica na freqüência industrial. Rigidez dielétrica é o campo elétrico, relação entre a tensão aplicada entre dois eletrodos, sob a qual ocorre perfuração do material em condições de ensaio especificadas, e a distância entre os mesmos (espessura da amostra). Tensão disruptiva é a tensão elétrica aplicada necessária para a perfuração do material.

Os filmes prensados foram cortados em corpos de prova com tamanho de $100 \mathrm{~mm} \times 100 \mathrm{~mm}$ (mínimo recomendado). Durante os ensaios foram lidas a temperatura e umidade da sala de testes e mediu-se a espessura de cada amostra usando um micrometro com precisão de 0,001 $\mathrm{mm}$.

As medidas foram realizadas em um equipamento Instronic, modelo HT 30.04 DM AM CA Série 494 (ou Triel, modelo TFI - 30), com velocidade de $0,5 \mathrm{kV} / \mathrm{seg}$ undo, mostrado na Figura 11 . $\mathrm{O}$ valor da tensão disruptiva foi lido diretamente no aparelho após perfuração do corpo de prova, expresso em volts (V). O valor da rigidez dielétrica é dado pela divisão do valor da tensão disruptiva pela espessura do corpo de prova, expresso em volts $/ \mathrm{mm}$. 


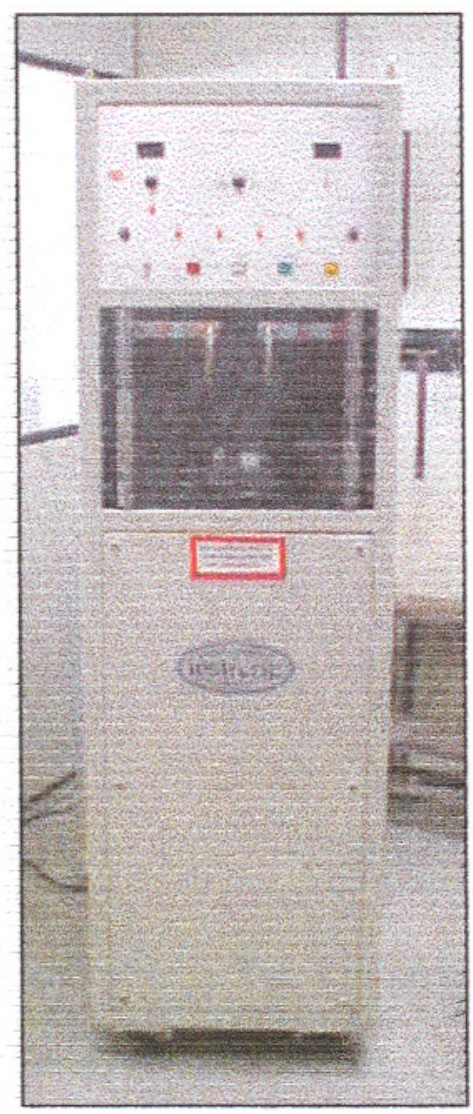

Figura 11 - Foto do equipamento de medição da tensão disruptiva.

\subsection{ANÁLISE ESTATISTIICA}

Os dados foram analisados estatisticamente utilizando-se o software Minitab. Para avaliar se a variaçäo da composição de cada material escolhido nas formulações (pigmento, carga, modificador de impacto e plastificantes) influenciava ou não nas propriedades medidas (Resistência à tração, Alongamento e Rigidez dielétrica), foi aplicado o Teste de Hipóteses através da análise da variância de cada grupo de amostras (ANOVA), conforme a fórmula abaixo, e a comparação dos subgrupos pelo gráfico "Boxplot". 


$$
S^{2}=\frac{\sum_{i=1}^{n}\left(x_{i}-\bar{x}\right)^{2}}{n}
$$

onde,

$$
\begin{aligned}
& \mathbf{S}^{2} \text { é a variância } \\
& \mathbf{x}_{\mathbf{i}} \text { é o i-ésimo dado } \\
& \overline{\mathrm{x}} \text { é a média aritmética dos dados } \\
& \mathrm{n} \text { é o número de dados }
\end{aligned}
$$

O Teste de Hipóteses é baseado na hipótese que as variações dos materiais não influenciam nas propriedades. Numericamente isto é medido pelo valor-p, que indica a probabilidade que o resultado esperado possa ocorrer quando a hipótese for verdadeira. Assim, quando o valor-p apresentou valor menor que 0,050 , ou seja, probabilidade menor que $5 \%$, a hipótese foi rejeitada, e considerou-se que a variação tinha grande significância nos valores das propriedades. Este valor é baseado em assumir "não existência de diferença" e depende dos interesses e conseqüências, para a maioria dos casos utiliza-se $0,050^{(17)}$.

O gráfico "Boxplot" foi utilizado para analisar a variabilidade entre os subgrupos das amostras. Possui formato retangular e é determinado a partir de medidas simples do conjunto de dados, sendo máximo, mínimo, primeiro quartil, mediana e terceiro quartil, conforme Figura 12. A mediana divide o conjunto de dados em dois, $50 \%$ estão acima deste valor e $50 \%$ abaixo. 0 primeiro quartil representa $75 \%$ dos dados e o terceiro quartil $25 \%$ dos dados (17) 


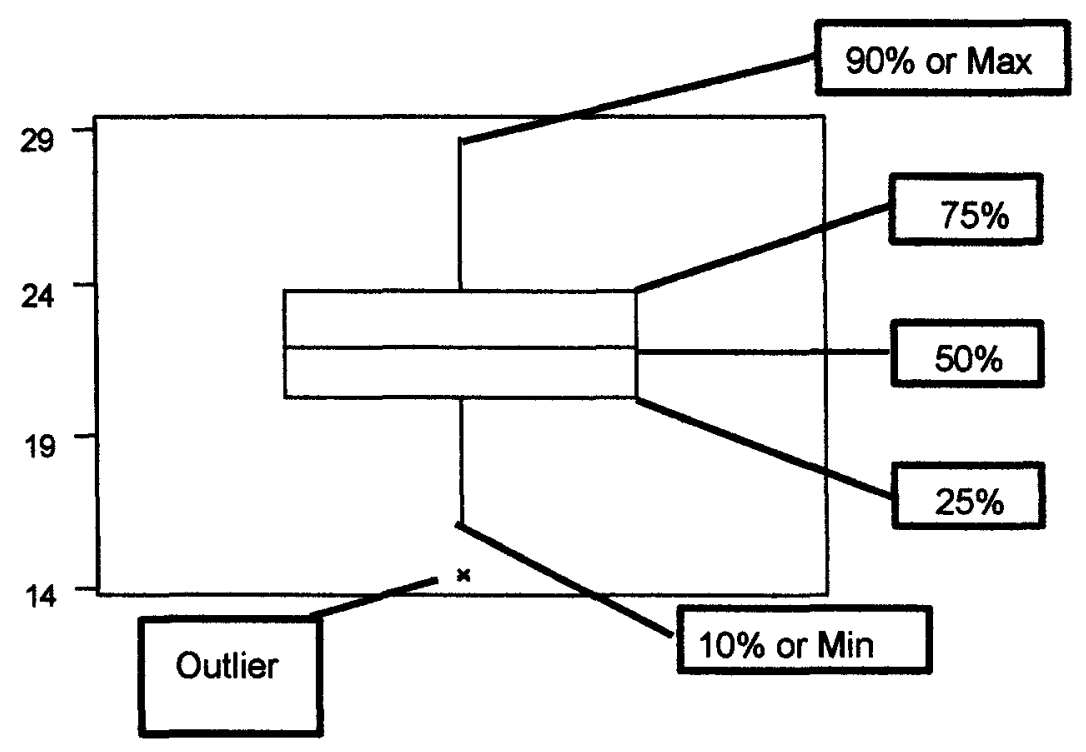

Figura 12 - Exemplo do gráfico "Boxplot". 


\section{RESULTADOS E DISCUSSÕES}

\subsection{MEDIDAS TÉRMICAS}

Nesta seção serão mostrados os resultados das medidas feitas utilizado as técnicas de análises térmicas DSC, DMA e TGA, com objetivo de verificar as transições de fases características das amostras, principalmente a transição vítrea, as propriedades mecânicas e a degradação das amostras.

\subsubsection{Calorimetria exploratória diferencial (DSC)}

Foram realizados os ensaios de DSC para todas as formulaçōes de amostras utilizadas neste projeto. Entretanto, conforme é mostrado nas curvas da Figura 13, não é possivel obter os dados referentes à transformação de fase $(T g)$ através das curvas de DSC. Como pode ser visto na Figura 13 ocorre variação da linha de base por volta de $0^{\circ} \mathrm{C}$ e aparece um pico endotérmico por volta de $300^{\circ} \mathrm{C}$, o qual é característico da fusão de materiais poliméricos. Como veremos a seguir, para a determinação da $T g$ foram realizados os ensaios de DMA que é uma técnica mais sensível que o DSC. Na medida de DMA a transição vítrea é caracterizada pela forte variação do módulo de armazenamento com a temperatura. 


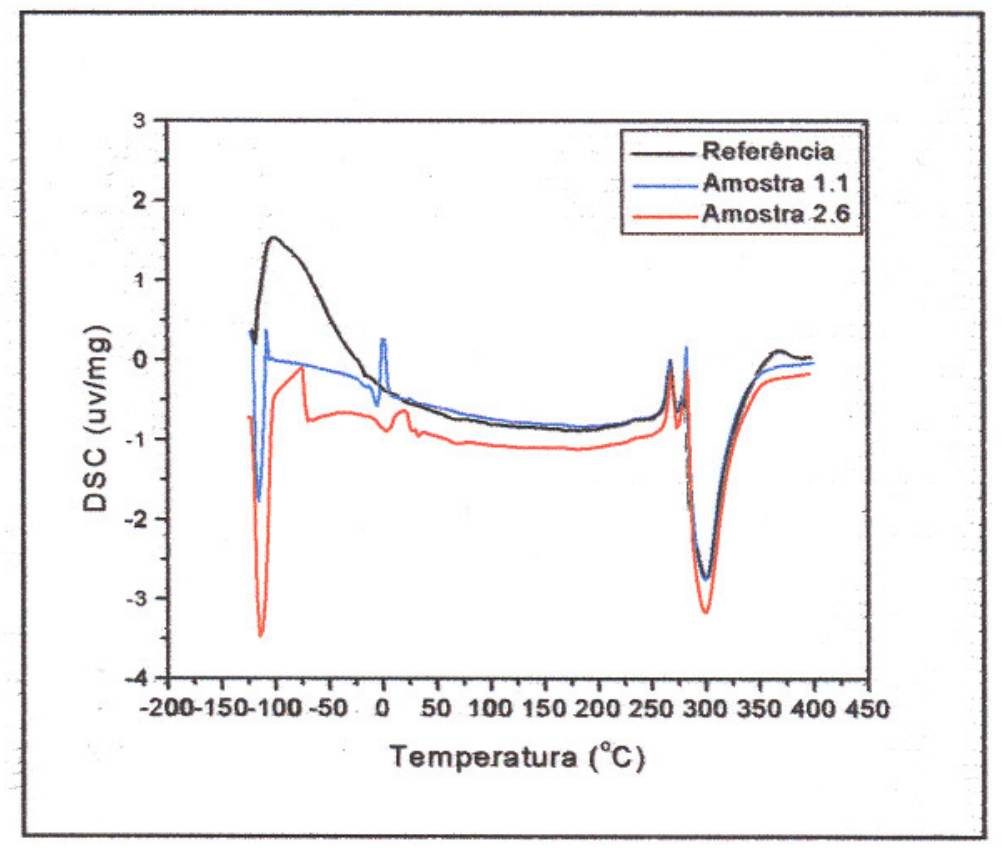

Figura 13 - Termogramas de DSC para as amostras de Referência, Amostra 1.1 (0.0 PHR pigmento) e Amostra 2.6 (30.0 PHR carga).

\subsubsection{Análise dinâmico-mecânica (DMA)}

As curvas de DMA do módulo de armazenamento (E') mostram que há uma mudança abrupta das propriedades mecânicas das amostras em torno da temperatura de transição vítrea $(T g)$, cujo valor pode ser obtido através dos picos das curvas de Tan $\delta$, outra medida obtida do DMA. Tan $\delta$ é proporcional à taxa da energia dissipada pela energia armazenada, onde é observado um aumento durante a transição entre diferentes mecanismos de deformação. Assim, das curvas de Tan $\delta$ em função da temperatura foram obtidas as temperaturas de transição vítreas das amostras.

A Figura 14 mostra que as curvas de E' apresentam uma queda abrupta em torno de $0{ }^{\circ} \mathrm{C}$ mas não ocorreram mudanças significativas quando se comparam as curvas das amostras com diferentes quantidades de pigmento na composiçäo. Conforme mostrado nas Figuras 15 e 16, os 
valores de $\mathrm{Tg}$, entre 20 a $30{ }^{\circ} \mathrm{C}$, não mostraram variações significativas nestas amostras. Este resultado pode ter ocorrido devido à limitada faixa de variação escolhida para o pigmento. De acordo com a literatura esta quantidade não é suficiente para influenciar as propriedades mecânicas e térmicas do material.

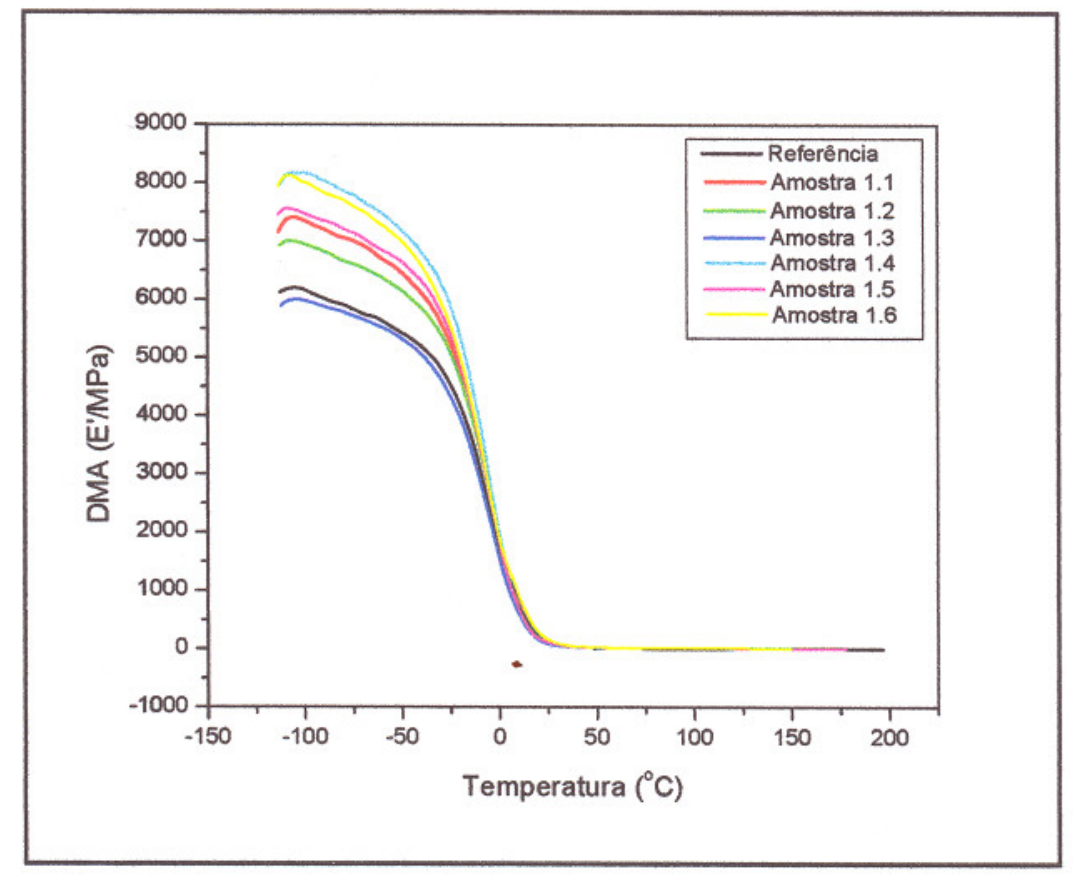

Figura 14 - Curvas de DMA para as amostras com a variação do pigmento na composição (PHR). 


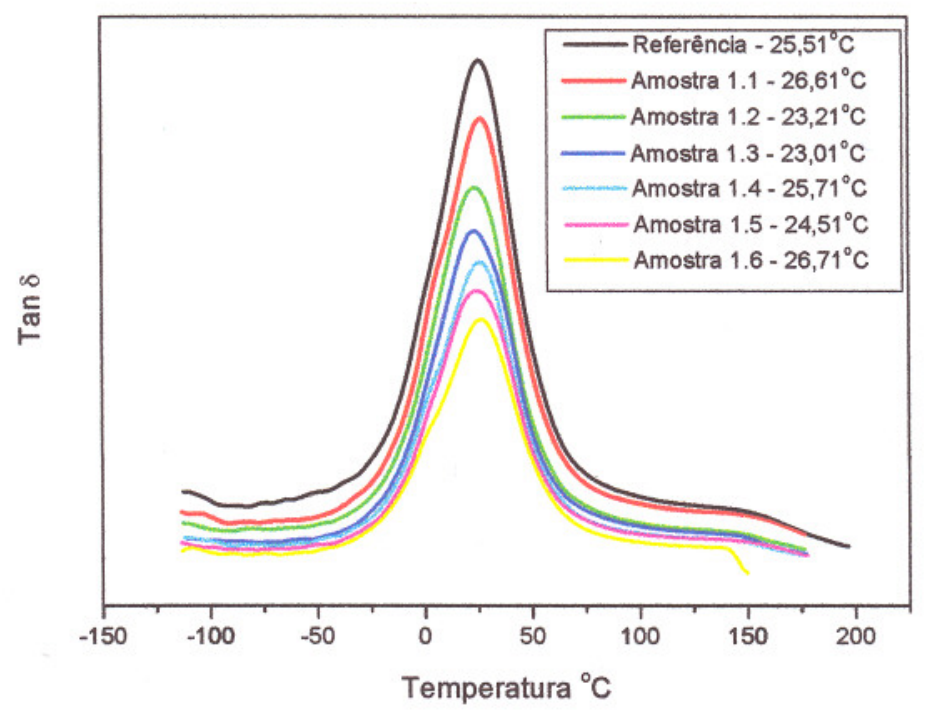

Figura 15 - Curvas de Tan $\delta$ para as amostras com a variação do pigmento na composição (PHR).

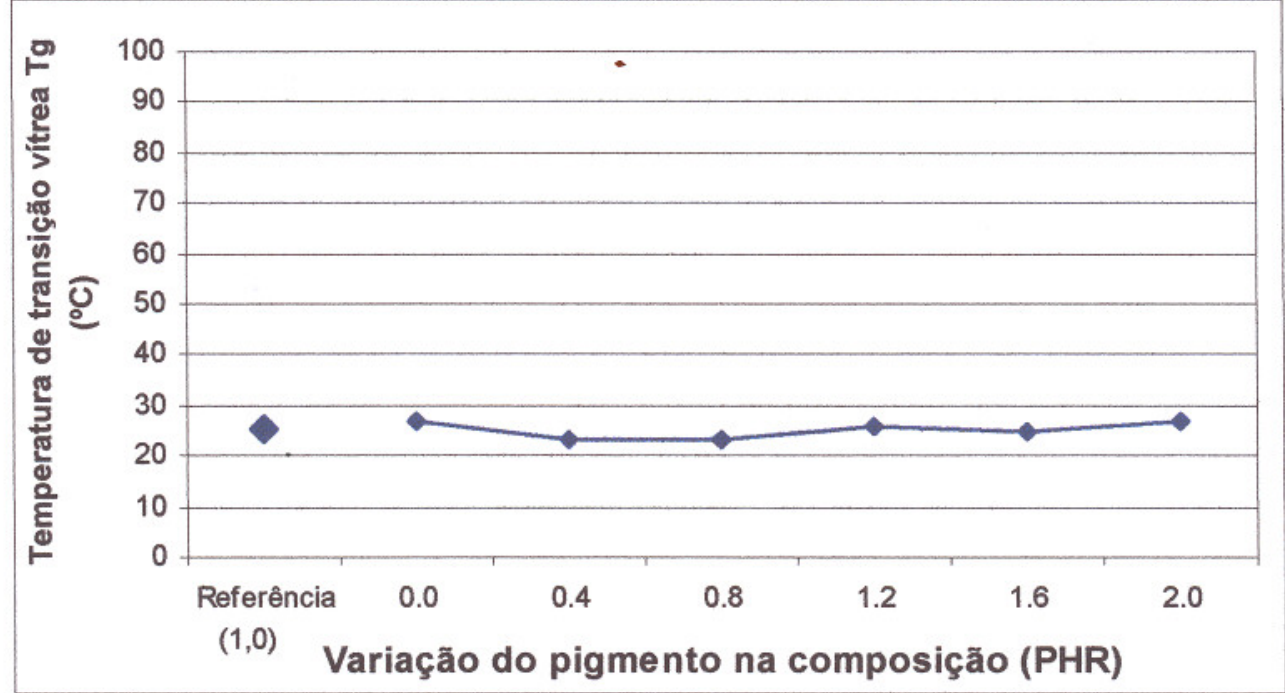

Figura 16 - Valores da temperatura de transição vítrea $(\mathrm{Tg})$ para as amostras com a variação do pigmento na composição (PHR).

Conforme é mostrado nas Figuras 17 e 20 o mesmo tipo de invariância dos resultados foi obtido para as amostras com a variação da quantidade de carga e de modificador de impacto na composição. 
Conseqüentemente, nas Figuras 18, 19, 21 e 22 os valores encontrados de $\mathrm{Tg}$ independem da quantidade de carga e de modificador de impacto.

A literatura mostra que o uso de cargas pode afetar as propriedades mecânicas, pois elas promovem irregularidades nas cadeias poliméricas. Porém, o resultado obtido aqui pode ser explicado pelo uso de plastificantes na composição base, pois eles podem compensar a adição da carga. $\mathrm{O}$ uso do modificador de impacto também tem forte influência nas propriedades mecânicas para aplicações de PVC rígido. Porém, para composições plastificadas o efeito de proporcionar uma fase dispersa no polímero é amenizado, o que pode explicar os resultados obtidos. Na indústria este tipo de material é utilizado apenas para conferir maciez ao composto.

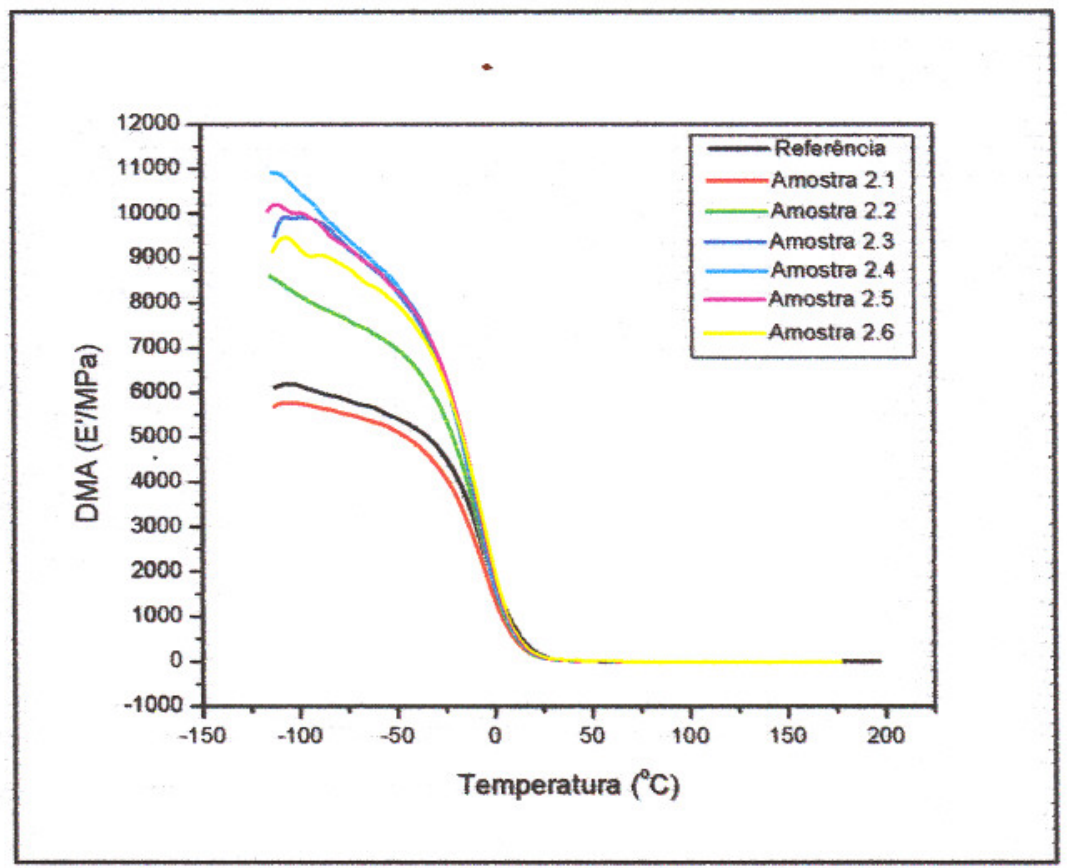

Figura 17 - Curvas de DMA para as amostras com a variação da carga na composição (PHR). 


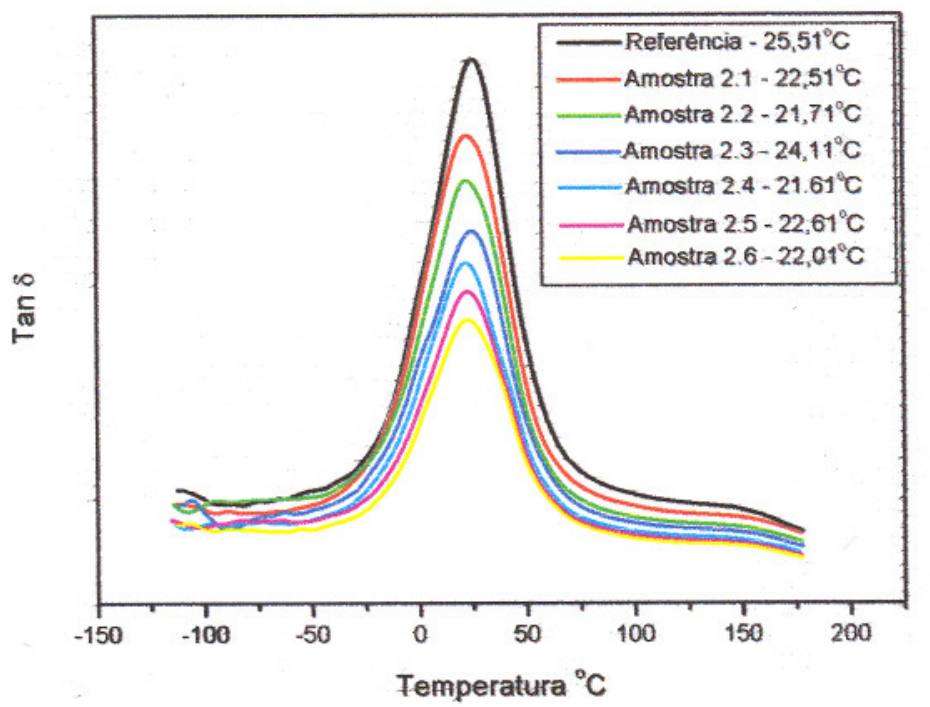

Figura 18 - Curvas de Tan $\delta$ para as amostras com a variação da carga na composiçäo (PHR).

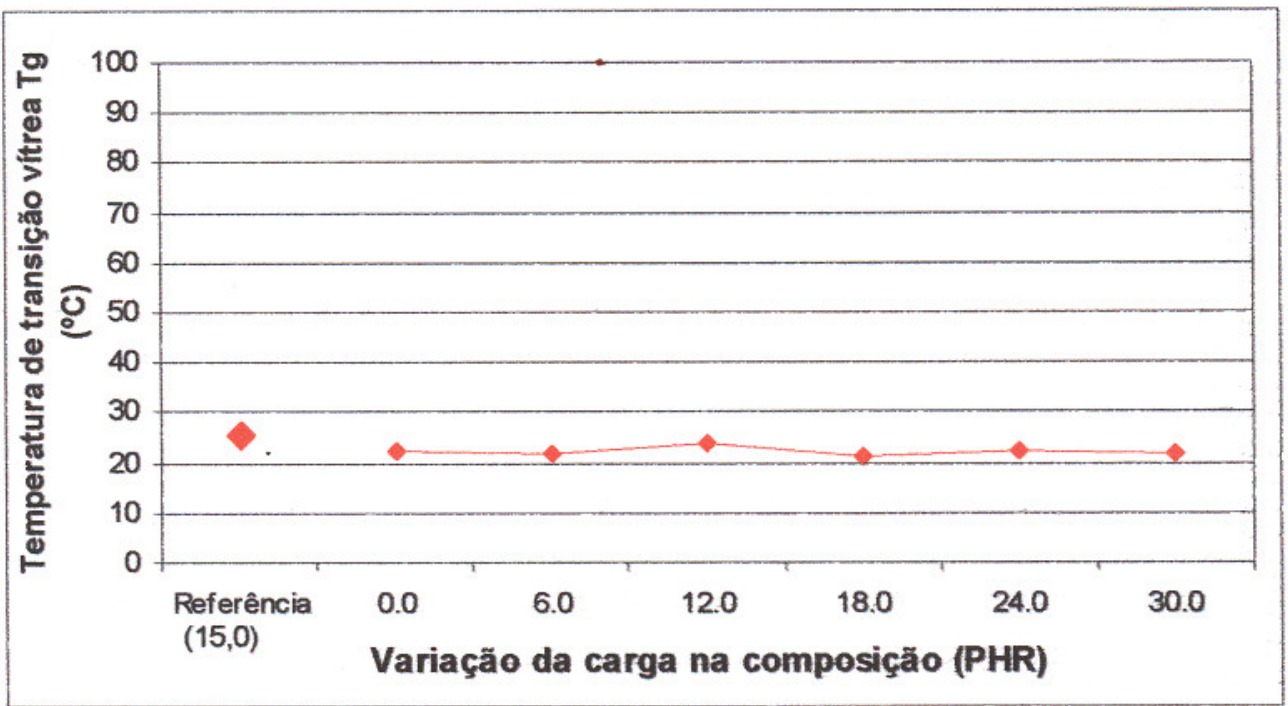

Figura 19 - Valores da temperatura de transição vítrea $(\mathrm{Tg})$ com a variação da carga na composição (PHR). 


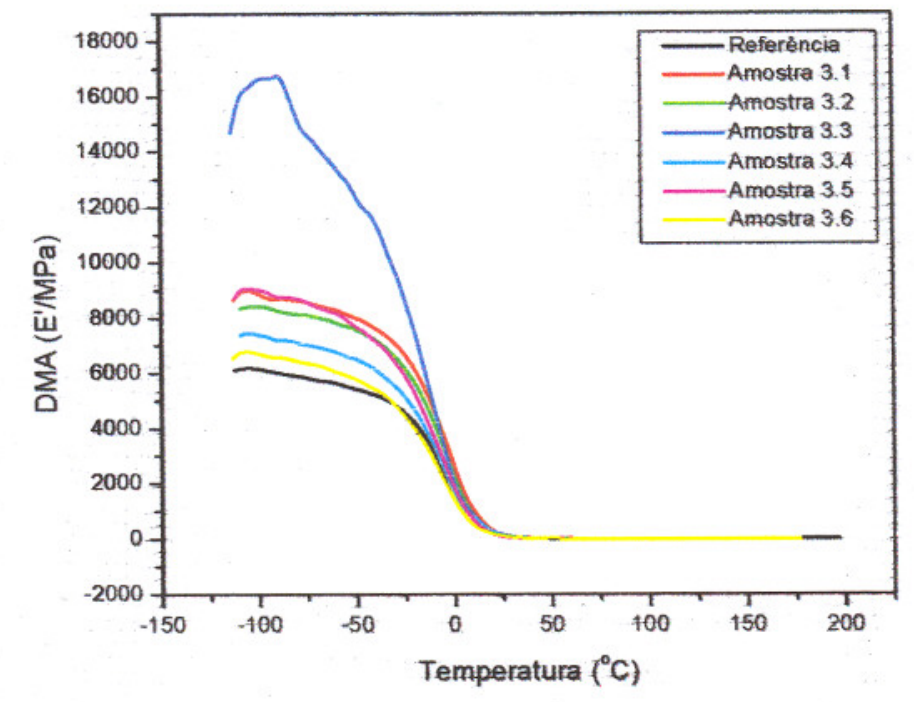

Figura 20 - Curvas de DMA para as amostras com a variação do modificador de impacto na composição (PHR).

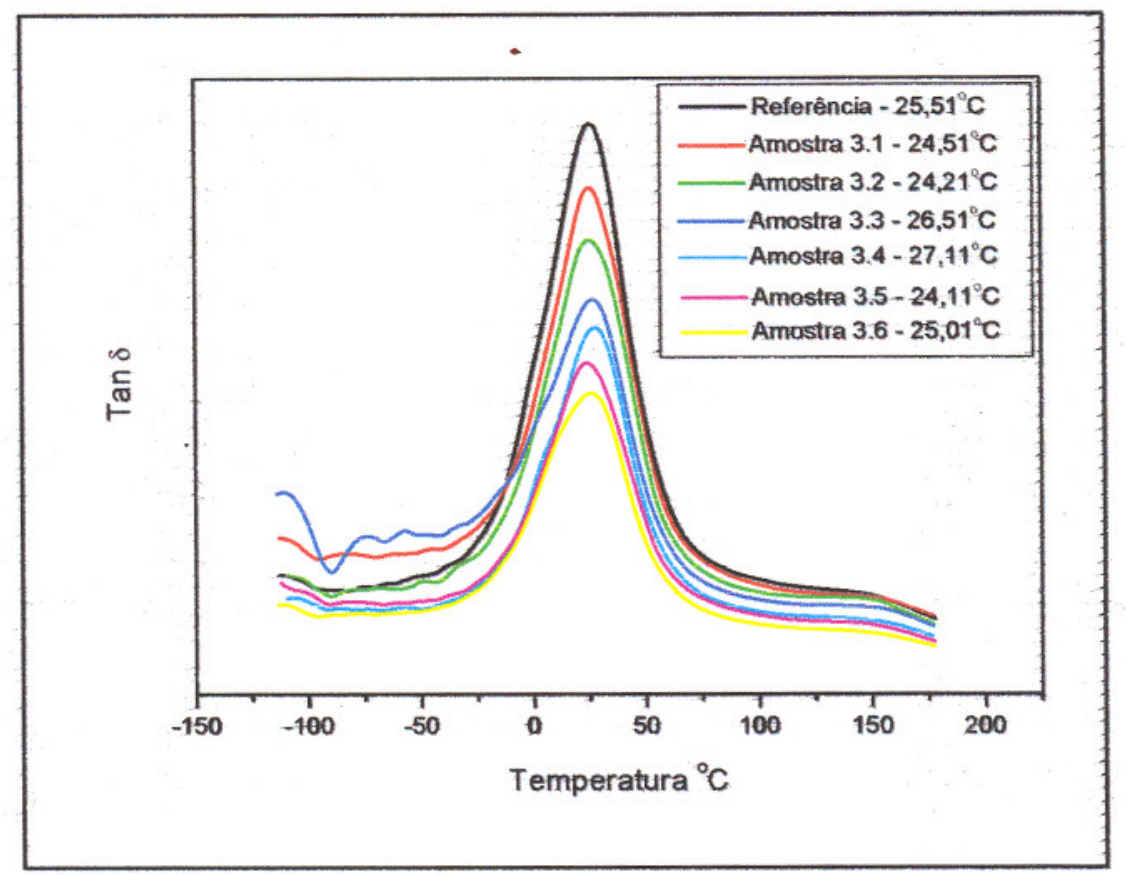

Figura 21 - Curvas de Tan $\delta$ para as amostras com a variação do modificador de impacto na composição (PHR). 


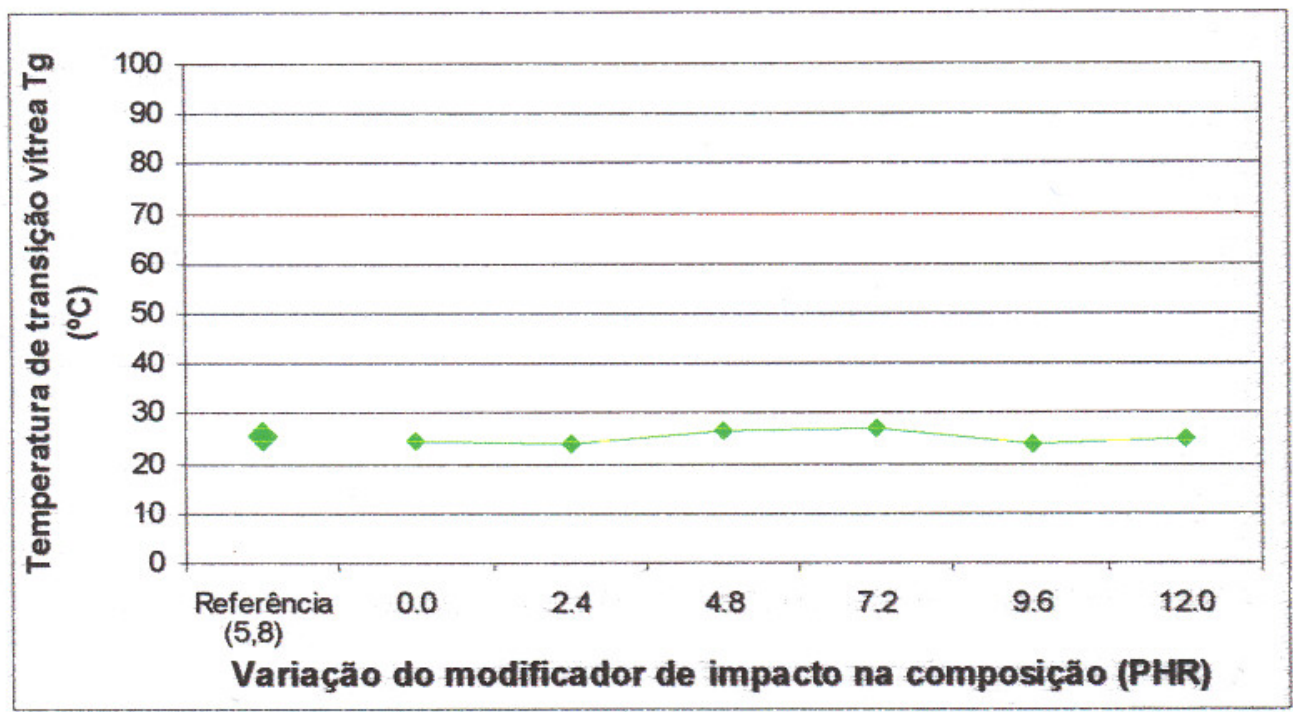

Figura 22 - Valores da temperatura de transiçäo vítrea $(\mathrm{Tg})$ com a variação do modificador de impacto na composição (PHR).

Os resultados da Figura 23, obtidos para as amostras com a variaçäo de plastificantes na composição, mostraram que se a quantidade de plastificantes aumentar, a queda abrupta da propriedade mecânica é deslocada para temperaturas mais baixas. As Figuras 24 e 25 mostram que os valores de $\mathrm{Tg}$ decrescem de forma aproximadamente linear em relação à quantidade de plastificantes na composição. Estes resultados comprovam os estudos encontrados na literatura, pois os plastificantes atuam como lubrificantes das cadeias poliméricas, possibilitando a movimentação mais fácil destas cadeias entre si com menor quantidade de energia. Os valores obtidos de $\mathrm{Tg}$ de acordo com a Figura 25 estäo de acordo com valores típicos encontrados na literatura e na indústria, sendo o $\mathrm{Tg}$ do PVC puro aproximadamente $80{ }^{\circ} \mathrm{C}$ e para um composto plastificado de aproximadamente $30^{\circ} \mathrm{C}$. 


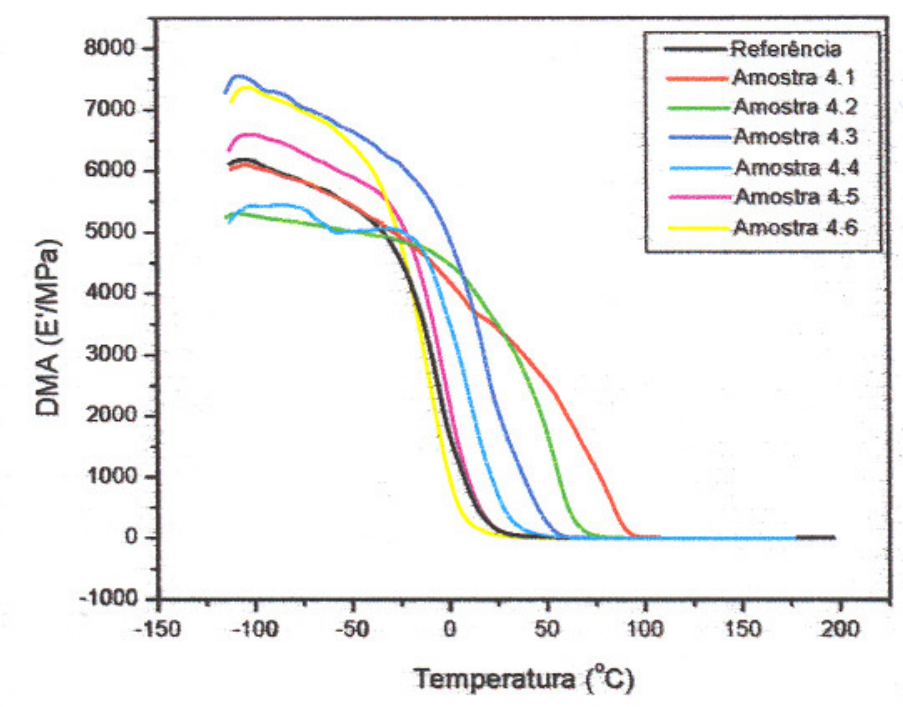

Figura 23 - Curvas de DMA para as amostras com a variação dos plastificantes na composição (PHR).

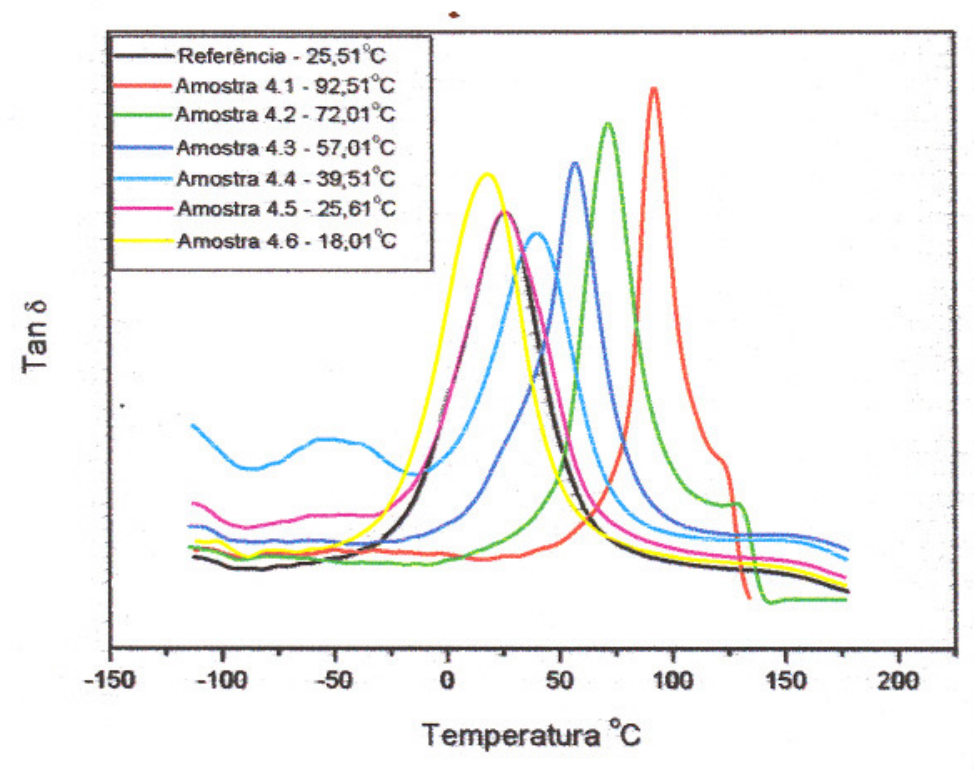

Figura 24 - Curvas de Tan $\delta$ para as amostras com a variação dos plastificantes na composição (PHR). 


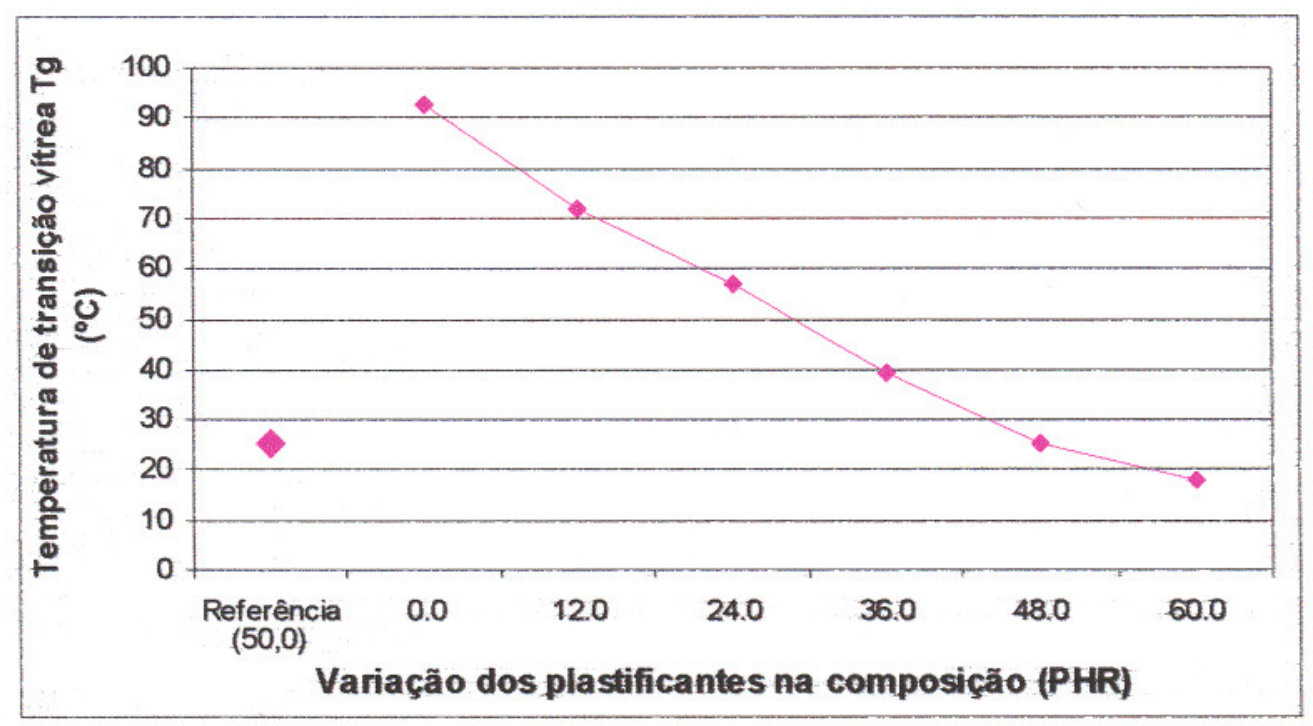

Figura 25 - Valores da temperatura de transição vítrea $(\mathrm{Tg})$ para a variação dos plastificantes na composição (PHR).

\subsubsection{Análise termogravimétrica (TGA)}

A Figura 26 ilustra os resultados obtidos nas análises termogravimétricas das amostras com variação de pigmento na composição. Como pode ser observado as curvas de perda de massa näo apresentam variações significativas das estabilidades térmicas para as amostras com variação de pigmento. Todas elas não apresentaram perda significativa de massa até temperaturas por volta de $250^{\circ} \mathrm{C}$, a partir da qual inicia-se 0 processo de degradação térmica do material, representada pela perda de massa bastante acentuada (aproximadamente $60 \%$ da massa inicial, principalmente 0 grupo dos plastificantes) entre as temperaturas de $250^{\circ} \mathrm{C}$ a $300^{\circ} \mathrm{C}$ (o pico da derivada da curva ocorre em torno de $295^{\circ} \mathrm{C}$ ). A partir de aproximadamente $450{ }^{\circ} \mathrm{C}$ ocorre uma perda de massa de aproximadamente $12 \%$ e após $575^{\circ} \mathrm{C}$, cerca de $17 \%$ de perda de massa. A reprodutibilidade dos resultados provavelmente foi devido à faixa da 
de pigmento ser pequena, não influenciando de maneira significativa no mecanismo de degradação do composto.

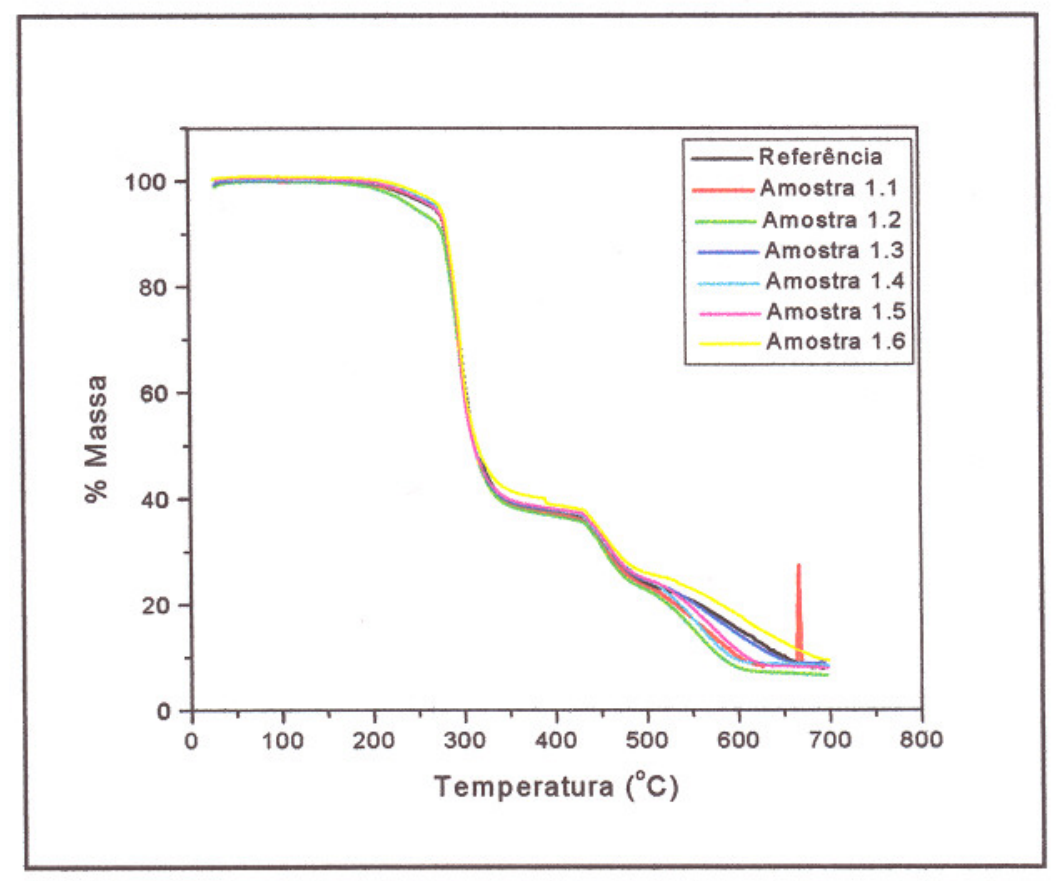

Figura 26 - Curvas termogravimétricas para as amostras com a variação do pigmento na composição (PHR).

Conforme mostrados na Figura 27 os resultados obtidos nas análises termogravimétricas das amostras com a variação de carga na composição mostraram apenas diferenças nos valores residuais das perdas de massa. 0 processo da degradação térmica ocorreu nas mesmas faixas de temperatura para as amostras com variação de pigmento. Porém, como são mostradas na Figura 28 , as massas residuais são proporcionais à quantidade de carga existente na amostra. Isto pode ser explicado pela faixa de temperatura utilizada nos testes não ter atingido o ponto de fusão da carga mineral utilizada. 


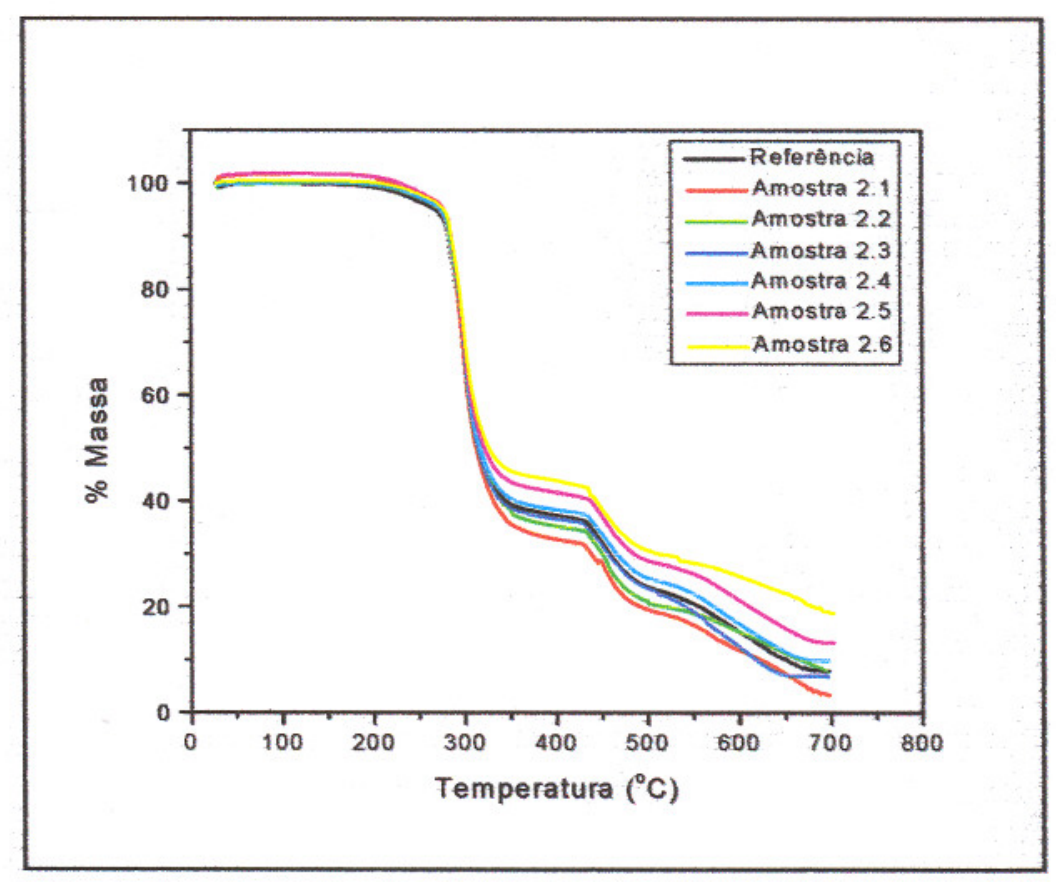

Figura 27 - Curvas termogravimétricas para as amostras com a variaçăo da carga na composição (PHR).

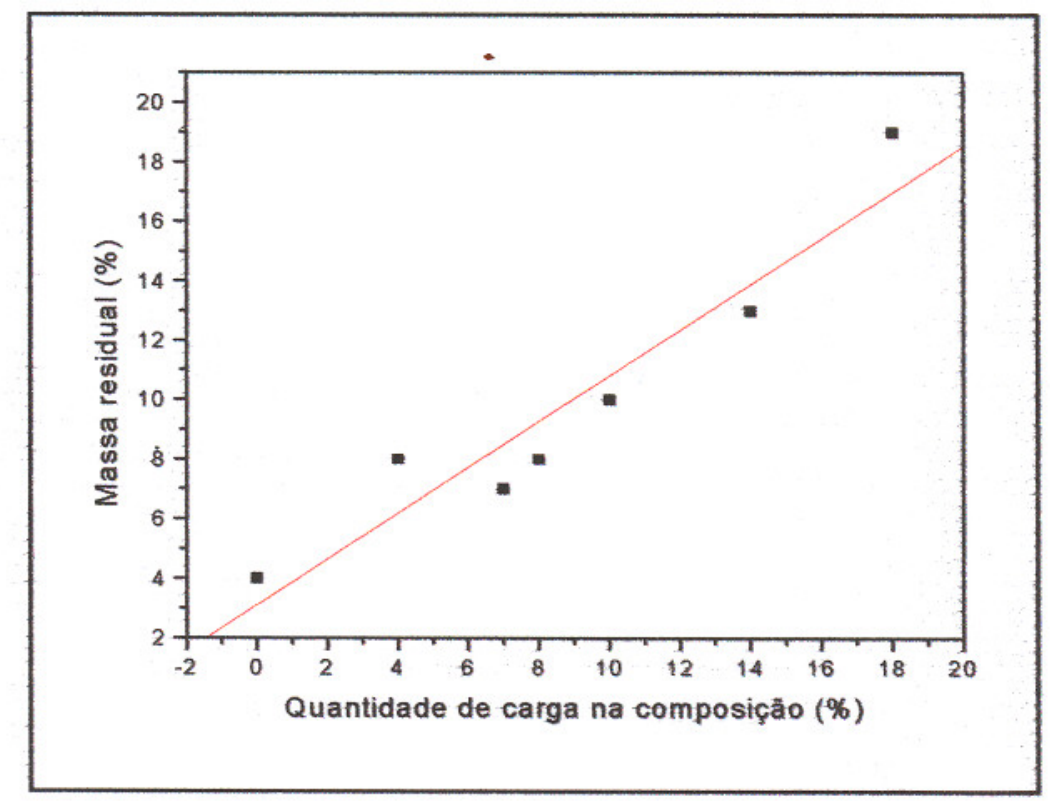

Figura 28 - Correlação entre a variação da carga na composição das amostras (\%) e a massa residual após os ensaios de TGA (\%). 
De acordo com a Figura 29 , para as amostras com variaçäo do modificador de impacto na composição, também não foram observadas variações na estabilidade térmica das amostras, tendo o mesmo comportamento para o processo de degradaçäo (três estágios, o primeiro em torno de $300{ }^{\circ} \mathrm{C}$, o segundo a partir de $450{ }^{\circ} \mathrm{C}$ e o terceiro aproximadamente $575^{\circ} \mathrm{C}$ ).

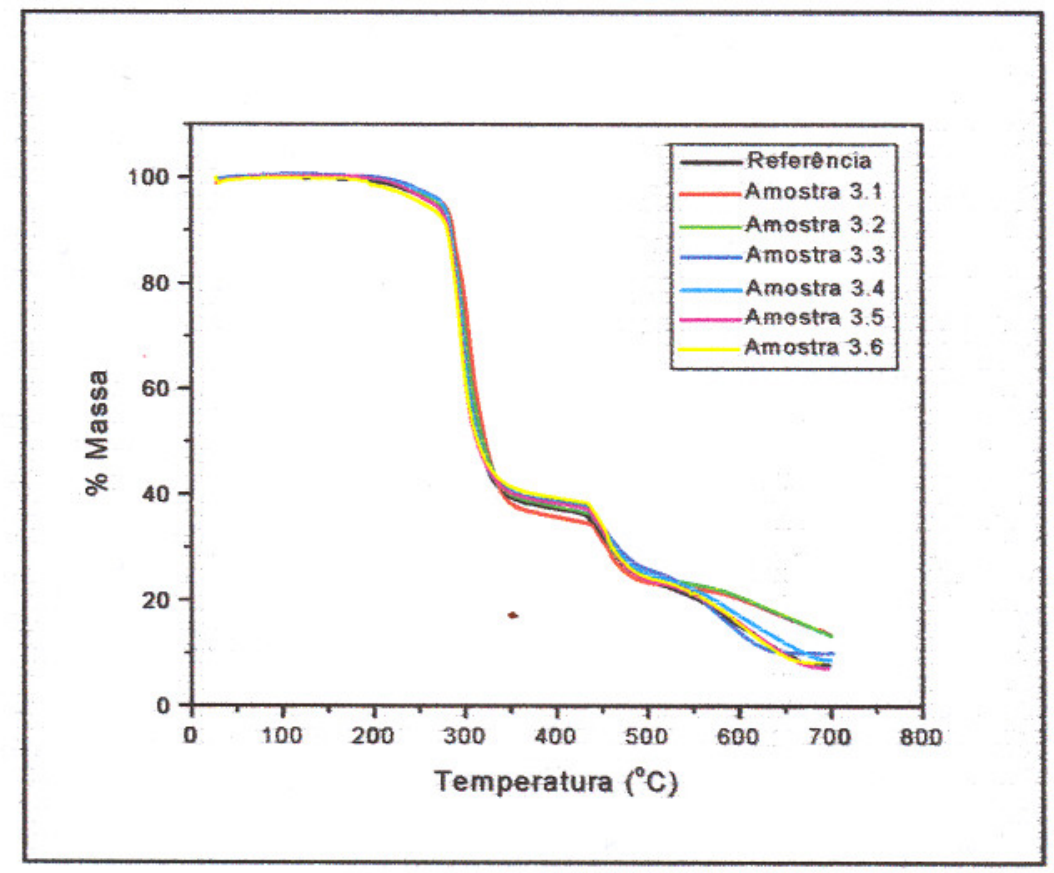

Figura 29 - Curvas termogravimétricas para as amostras com a variação do modificador de impạcto na composição (PHR).

Conforme mostrados na Figura 30 os resultados obtidos das análises termogravimétricas para as amostras com variação de plastificantes na composição mostraram diferenças no comportamento da estabilidade térmica de cada material. 


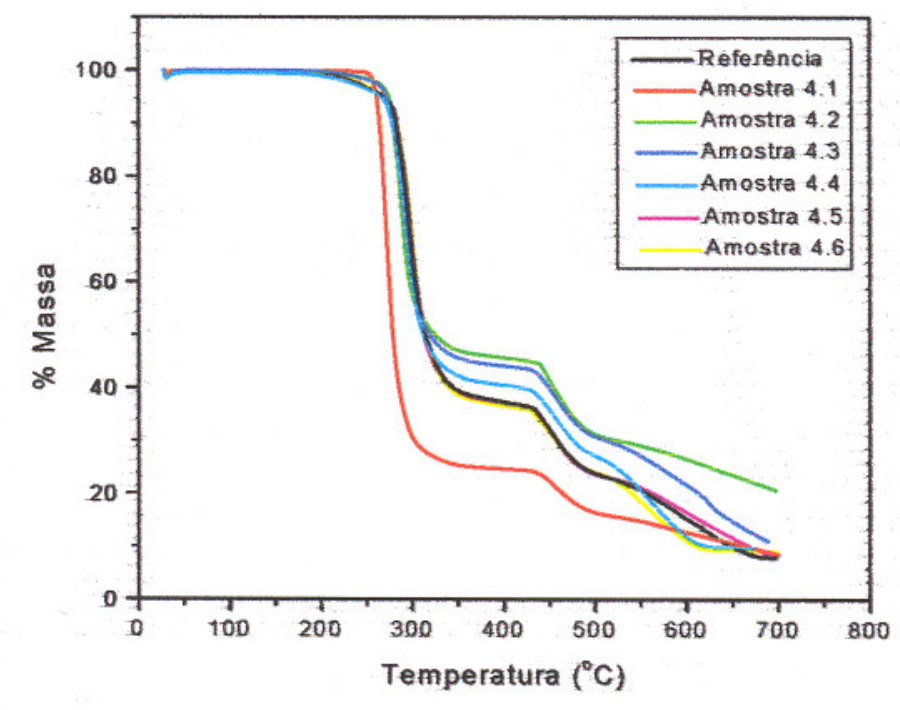

Figura 30 - Curvas termogravimétricas para as amostras com a variação dos plastificantes na composição (PHR).

Todas as amostras não apresentaram perda significativa de massa até temperaturas por volta de $250^{\circ} \mathrm{C}$, a partir da qual inicia-se o processo de degradação térmica do material. Para a amostra com 0,0 PHR de plastificantes a perda de massa acentuada (aproximadamente $75 \%$ da massa inicial) ocorreu entre as temperaturas de 250 a $270{ }^{\circ} \mathrm{C}$, sendo sucedida por uma perda de massa menos acentuada (aproximadamente 15\%) a partir de $450^{\circ} \mathrm{C}$. Para as amostras com 12, 24 e 36 PHR de plastificantes a perda de massa acentuada (aproximadamente $55 \%$ da massa inicial) ocorreu entre as temperaturas de 260 a $290{ }^{\circ} \mathrm{C}$, sendo sucedida por uma perda de massa menos acentuada (aproximadamente $35 \%$ ) a partir de $450{ }^{\circ} \mathrm{C}$. Para as amostras com 48 e 60 PHR de plastificantes a perda de massa acentuada (aproximadamente $60 \%$ da massa inicial) ocorreu entre as temperaturas de 250 a $300^{\circ} \mathrm{C}$, sendo 
sucedida por uma perda de massa menos acentuada (aproximadamente $30 \%$ ) a partir de $450^{\circ} \mathrm{C}$. Estes resultados comprovam que a quantidade de plastificantes melhora a estabilidade térmica do material. Isto pode ser explicado por reações de componentes dos plastificantes com o $\mathrm{HCl}$ formado durante o processo de degradação do $\mathrm{PVC}$, retardando a liberação de $\mathrm{Cl}$ da molécula do polímero.

\subsection{MEDIDAS MECÂNICAS}

\subsubsection{Resistência à tração e Alongamento}

Durante os ensaios de resistência à tração e alongamento foram feitas leituras da temperatura e umidade da sala de teste. Estes valores e os resultados das medidas dos ensaios estão apresentados no Anexo B.

De acordo com a Figura 31, o aumento da quantidade de pigmento na formulação aparentemente levou a um aumento na resistência à tração. Porém, analisando os dados estatisticamente, a variância resultou no valor de 0,297 , o que significa que a variação do pigmento na composição, na faixa escolhida para este trabalho ( 0 a 2 PHR), não influencia os valores de resistência à tração. A Figura 32 do gráfico "Boxplot" indicou que todos subgrupos das amostras estão na mesma faixa de variação. Lembramos que uma variância menor que 0,050 indicaria que houve variação significativa dos grupos. 


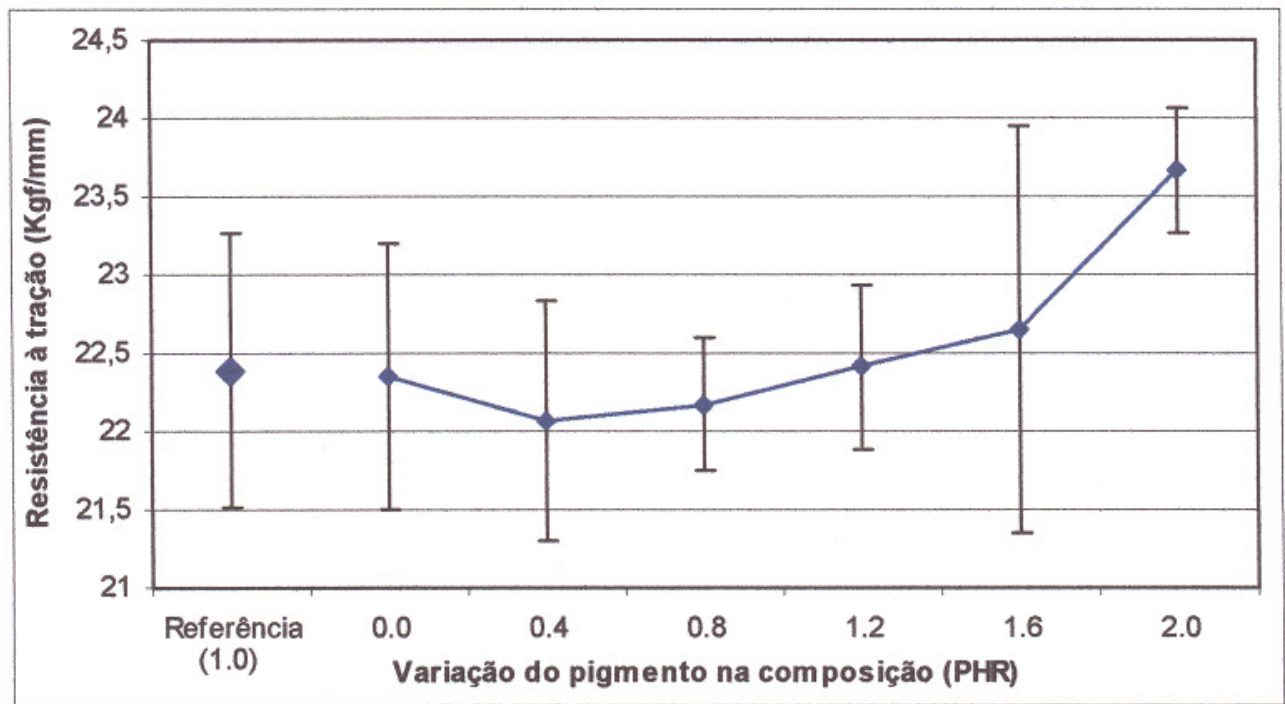

Figura 31 - Gráfico dos valores de resistência à tração (Kgf/mm) em relação à variação do pigmento na composição (PHR).

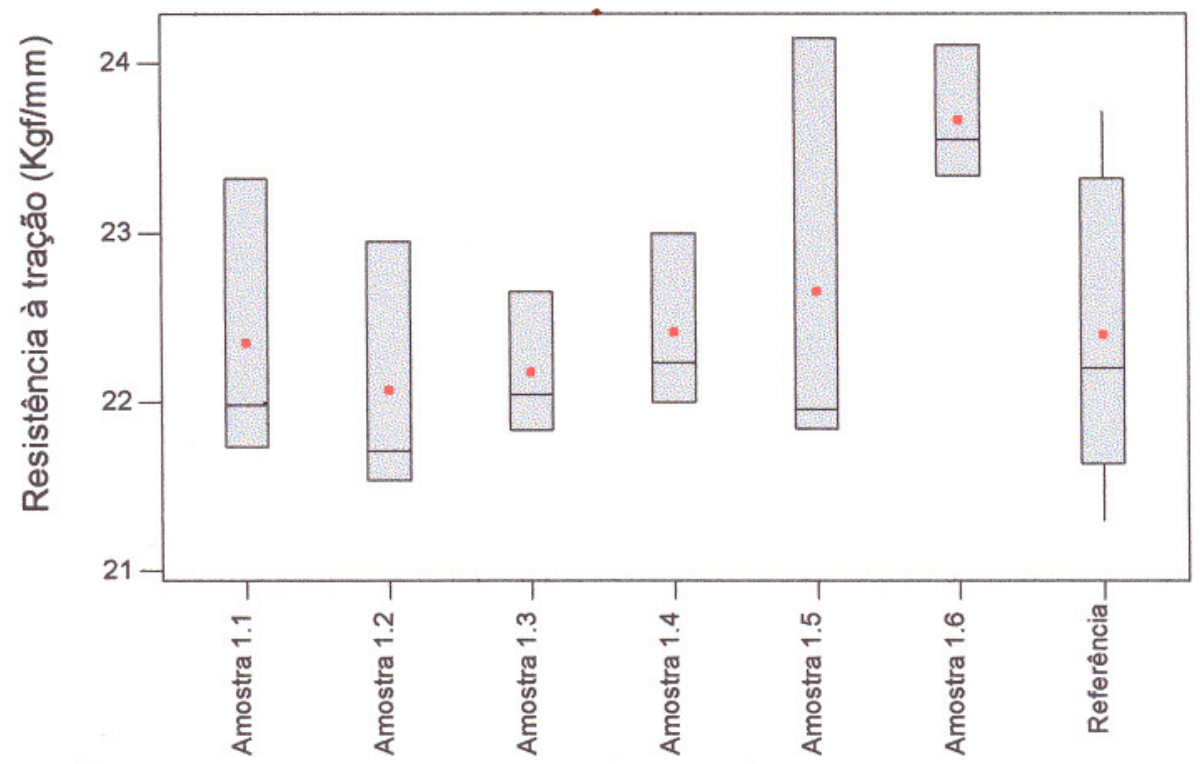

Figura 32 - Gráfico "Boxplot" da resistência à tração (Kgf/mm) versus a variação do pigmento (Amostra 1.1 a Amostra 1.6 e Referência). 
Na Figura 33 não se observa qualquer dependência dos valores de alongamento com a variação do pigmento na formulação. Isto pode ser comprovado estatisticamente analisando-se o valor da variância, que foi 0,144 e o gráfico "Boxplot" mostrado na Figura 34. Estes resultados podem ser explicados devido ao valor da faixa escolhida de variação da quantidade do pigmento ser pequena, e conforme a literatura ${ }^{(12)}$, não se espera que ocorram grandes mudanças nas propriedades físicas das amostras.

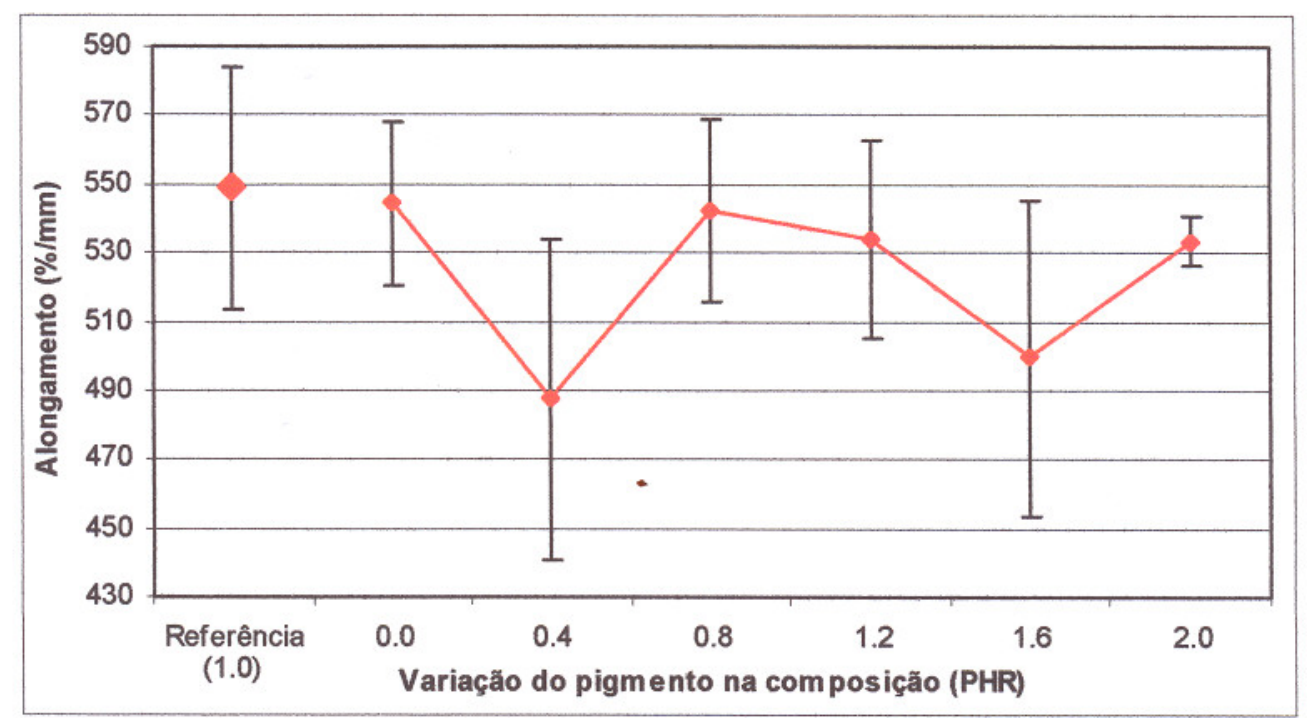

Figura 33 - Gráfico dos valores de alongamento $(\% / \mathrm{mm})$ em relação à variação do pigmento na composição (PHR). 


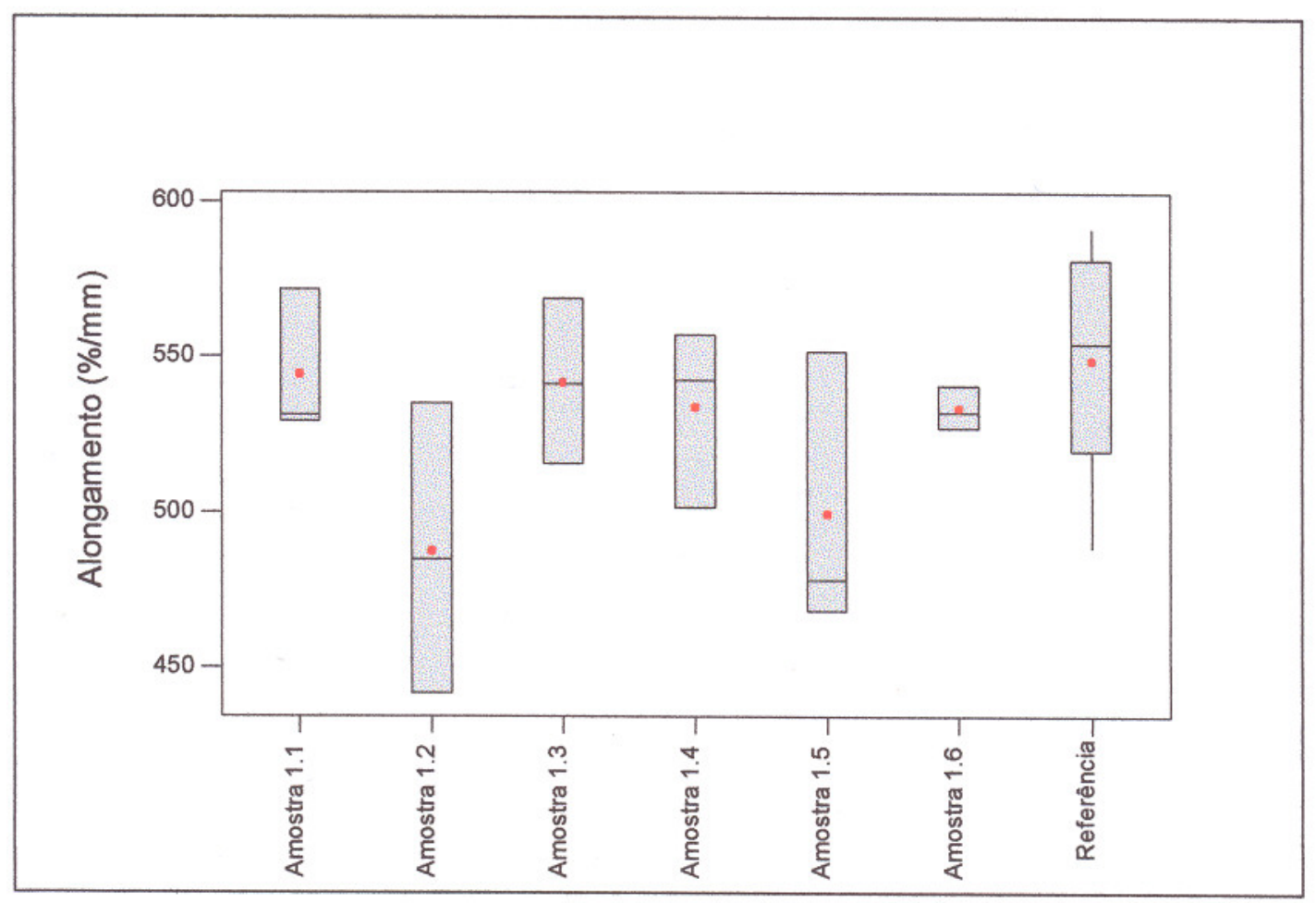

Figura 34 - Gráfico "Boxplot" do alongamento $(\% / \mathrm{mm})$ versus a variação do pigmento (Amostra 1.1 a Amostra 1.6 e Referência).

A Figura 35 mostra que a variação da carga na composição levou a diminuição nos valores de resistência à tração, a partir da quantidade de 6 PHR. Esta tendência pode ser comprovada estatisticamente, sendo o valor de variância de 0,001. Analisando-se a Figura 36, o gráfico "Boxplot" mostra dois grupos distintos em relação às faixas de variação. 


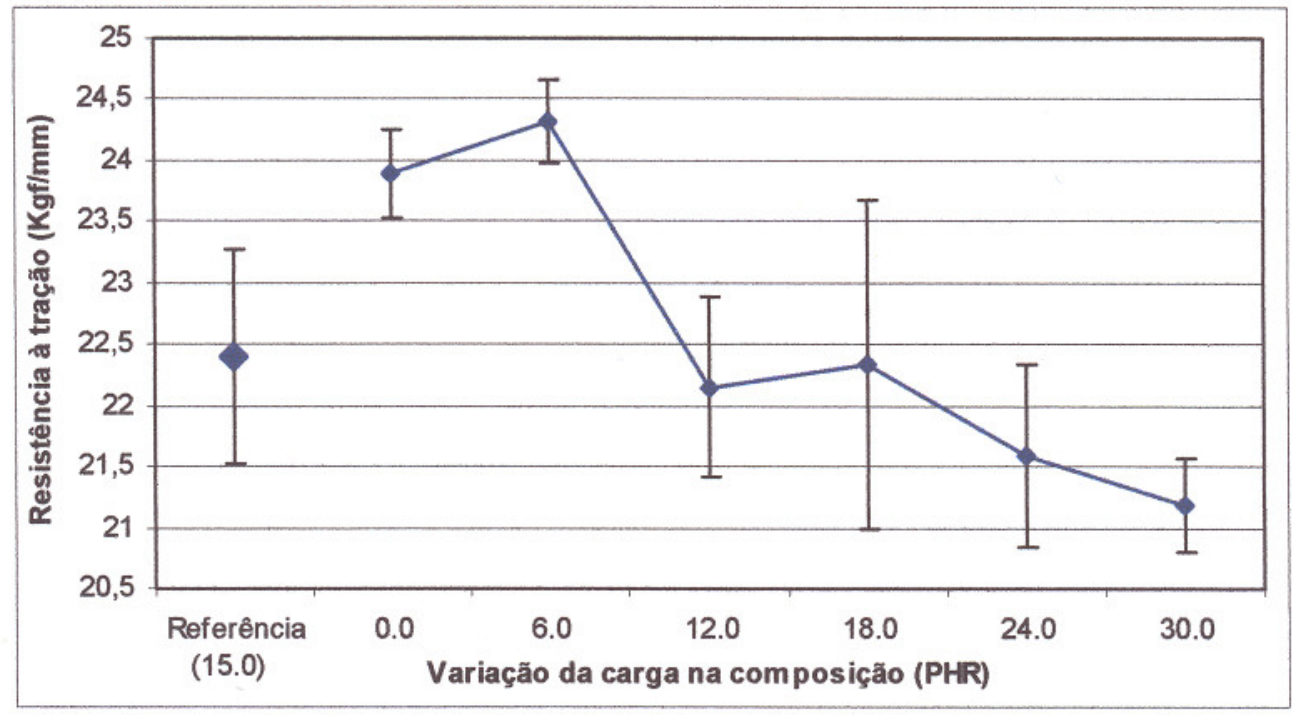

Figura 35 - Gráfico dos valores de resistência à tração $(\mathrm{Kgf} / \mathrm{mm})$ em relação à variação da carga na composição (PHR).

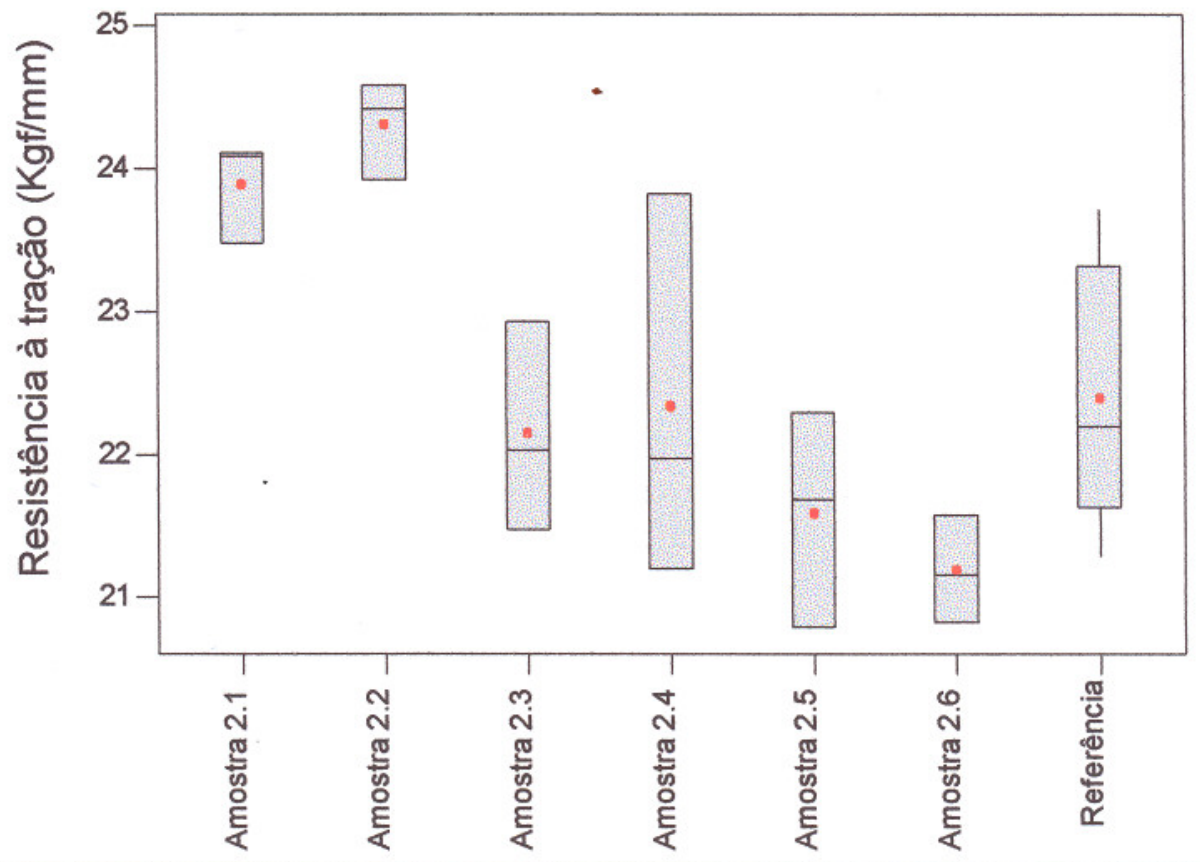

Figura 36 - Gráfico "Boxplot" da resistência à tração $(\mathrm{Kgf} / \mathrm{mm})$ versus a variação da carga (Amostra 2.1 a Amostra 2.6 e Referência). 
A Figura 37 mostra que os valores do alongamento diminuíram com o aumento da quantidade de carga, isto é, o mesmo comportamento do caso anterior. A análise estatística resultou o valor de variância de 0,004 e de acordo com a Figura 38 observaram-se dois grupos distintos de variação no gráfico "Boxplot". A dependência observada das propriedades físicas com o aumento da quantidade de carga na composição confirmou os resultados encontrados em outros trabalhos citados na literatura ${ }^{(7)}$.

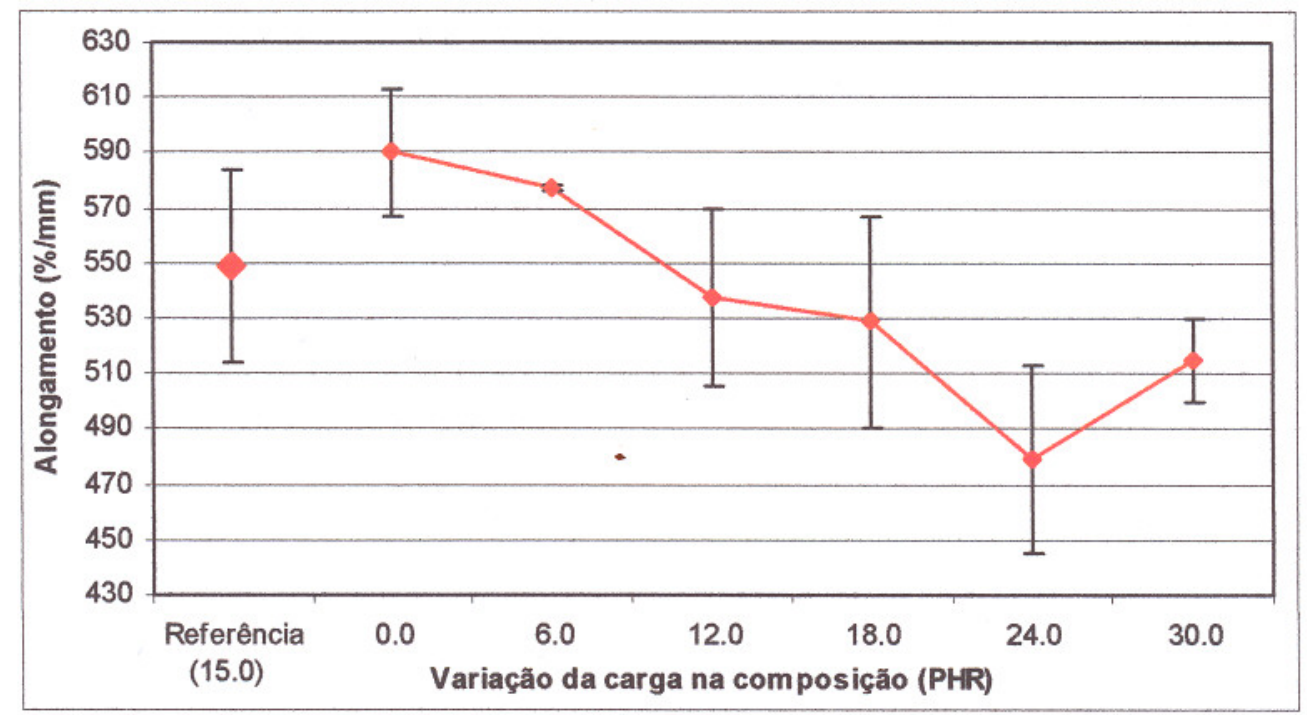

Figura 37 - Gráfico dos valores de alongamento $(\% / \mathrm{mm})$ em relação à variação da carga na composição (PHR). 


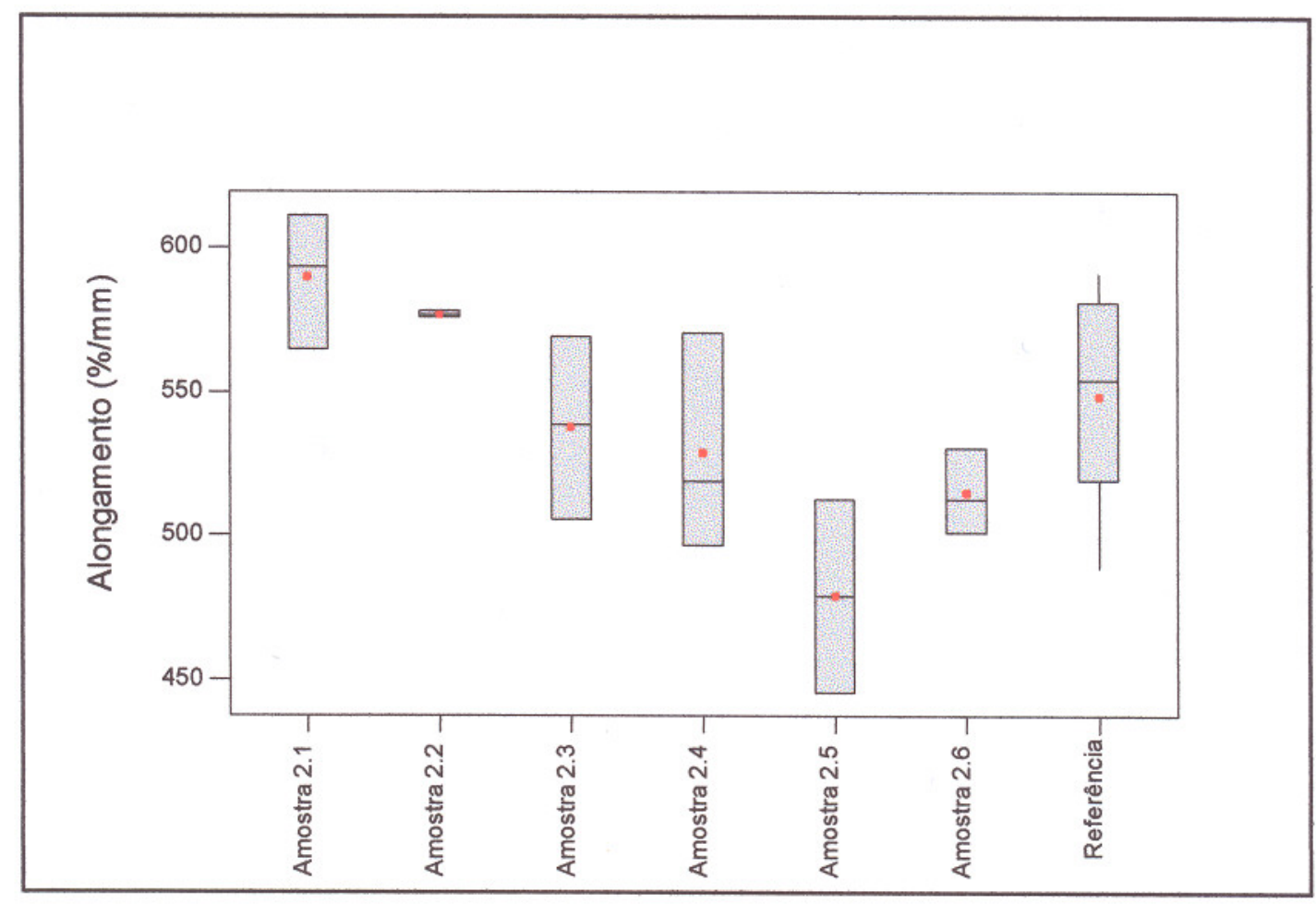

Figura 38 - Gráfico "Boxplot" do alongamento $(\% / \mathrm{mm})$ versus a variação da carga (Amostra 2.1 a Amostra 2.6 e Referência).

O aumento da quantidade. do modificador de impacto também mostrou, conforme a Figura 39, a diminuição da resistência à tração. 0 estudo estatístico comprovou esta tendência pelo valor de variância de 0,018 e através do gráfico "Boxplot" da Figura 40. 


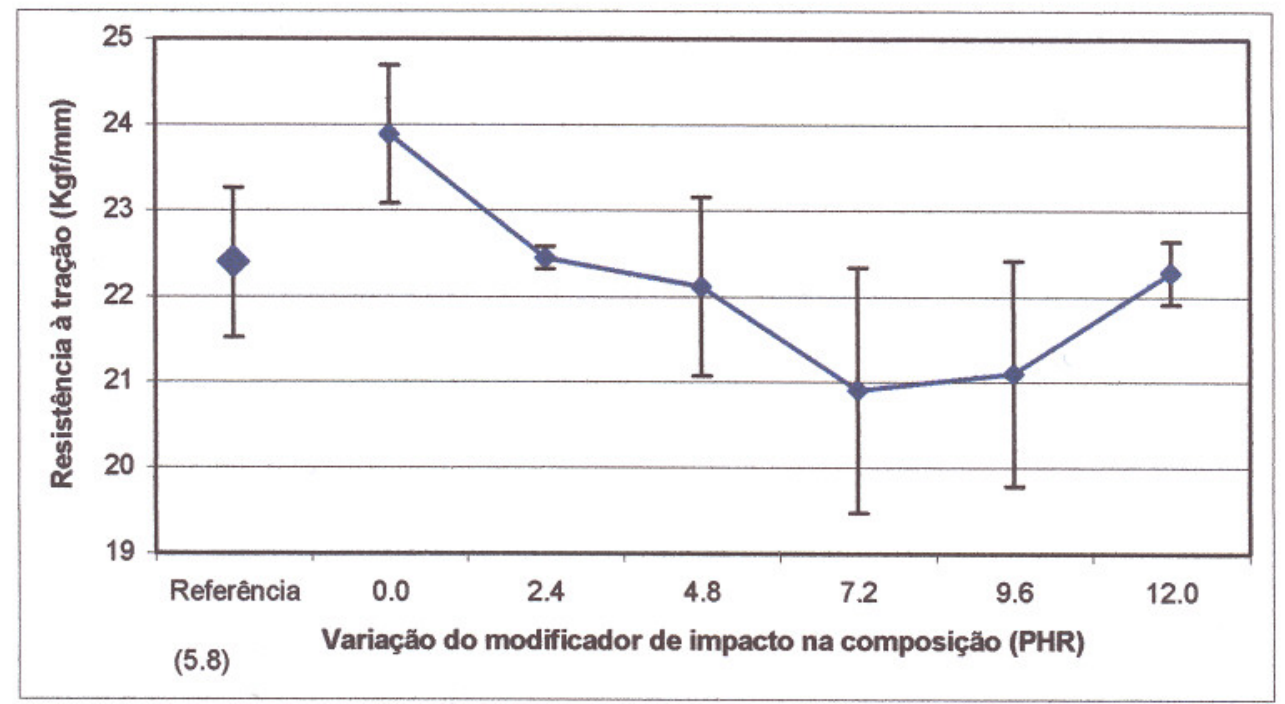

Figura 39 - Gráfico dos valores de resistência à tração $(\mathrm{Kgf} / \mathrm{mm})$ em relação à variação do modificador de impacto na composição (PHR).

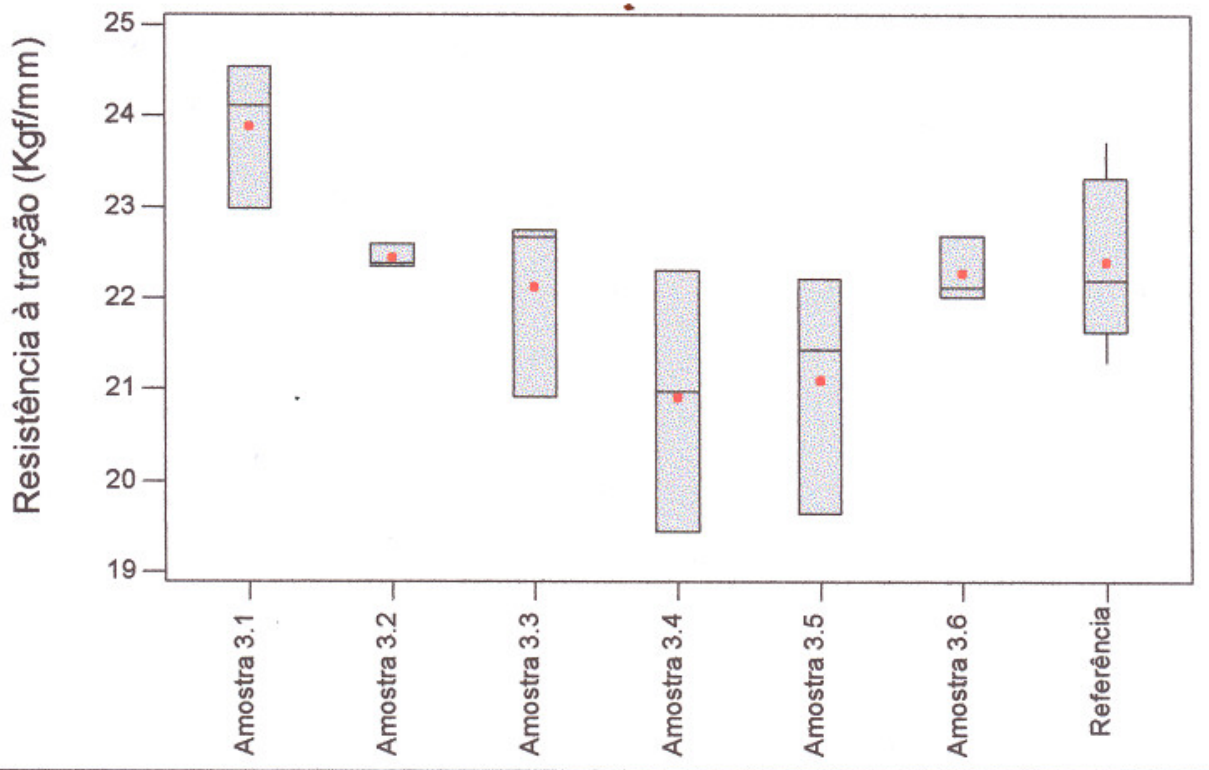

Figura 40 - Gráfico "Boxplot" da resistência à tração $(\mathrm{Kgf} / \mathrm{mm})$ versus a variação do modificador de impacto (Amostra 3.1 a Amostra 3.6 e Referência). 
A análise dos valores de alongamento em relação ao aumento da quantidade de modificador de impacto apresentou conforme as Figuras $41 \mathrm{e}$ 42 uma grande oscilação. Porém o resultado da análise da variância, cujo valor foi de 0.039 , mostrou que o aumento do modificador de impacto tem influência nos valores de alongamento, levando à diminuição dos valores desta propriedade. Estes resultados, referentes à diminuição do valores de alongamento também estão de acordo com a literatura ${ }^{(10)}$.

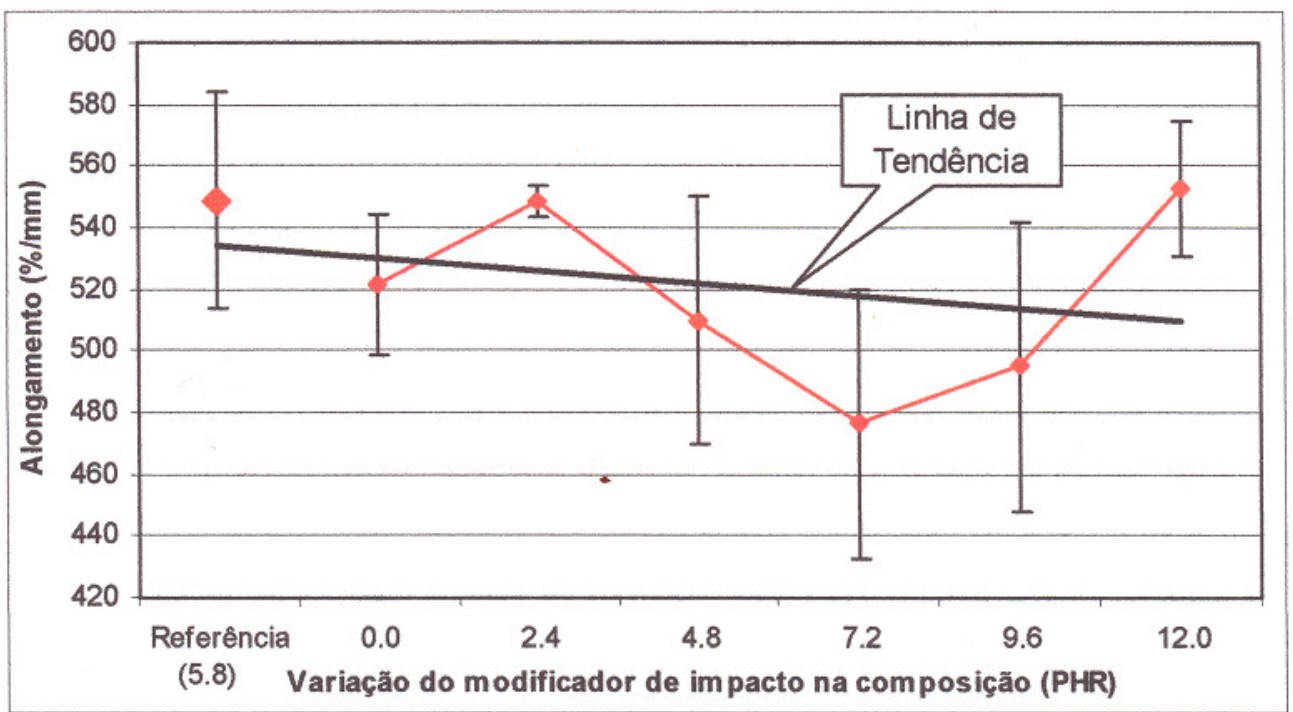

Figura 41 - Gráfico dos valores de alongamento $(\% / \mathrm{mm})$ em relação à variação do modifiçador de impacto na composição (PHR). 


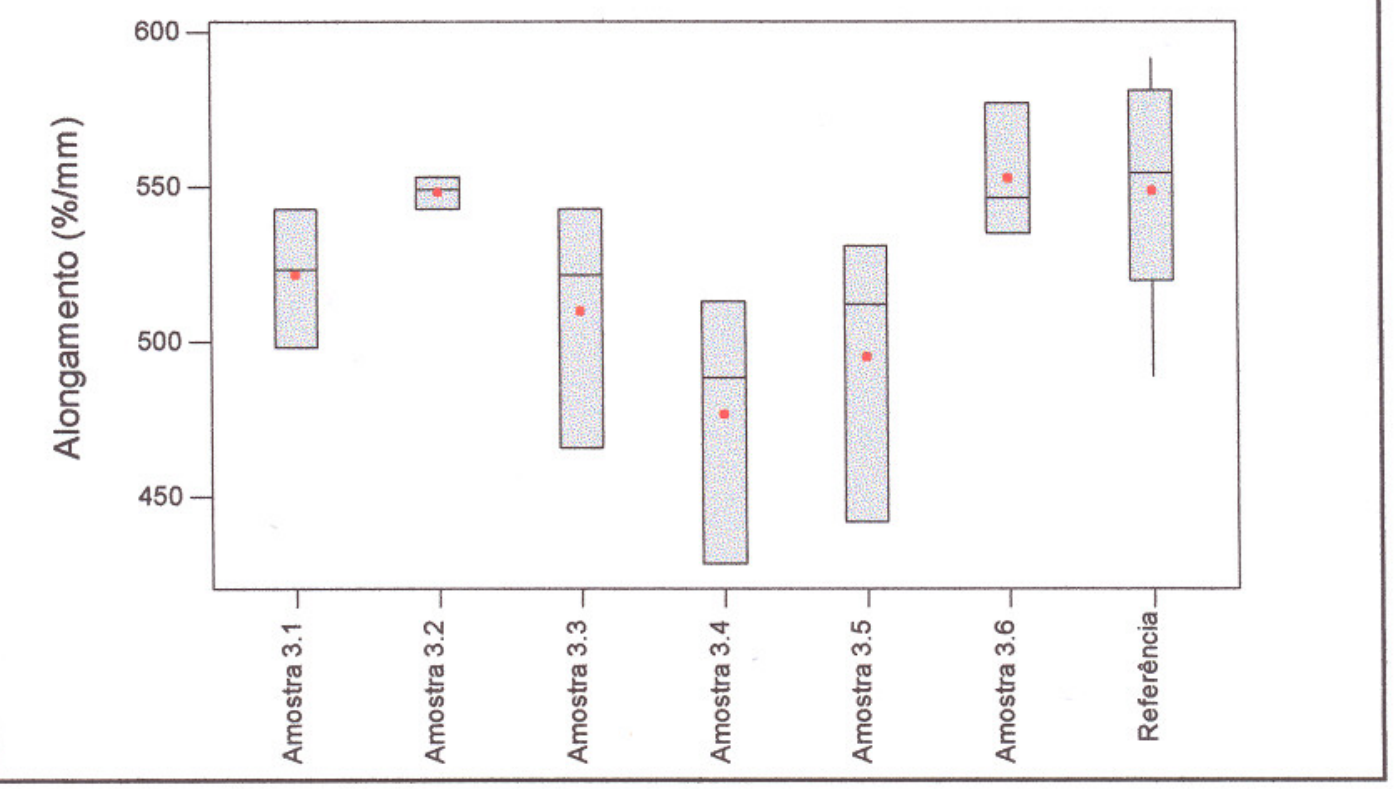

Figura 42 - Gráfico "Boxplot" do alongamento $(\% / \mathrm{mm})$ versus a variação do modificador de impacto (Amostra 3.1 a Amostra 3.6 e Referência).

Conforme a Figura 43 observọu-se que o aumento da quantidade dos plastificantes leva à diminuição dos valores de resistência à tração. Estatisticamente comprovou-se a forte influência dos plastificantes nesta propriedade, de acordo com 0 valor de variância de 0,000 e o gráfico "Boxplot" mostrado na Figura 44. Não foi possível realizar os ensaios para as Amostras 4.1 e 4.2 devido à alta dureza do material, pois a máquina de ensaio Kratos utilizada não possuía recursos de células de carga apropriadas para durezas mais altas. 


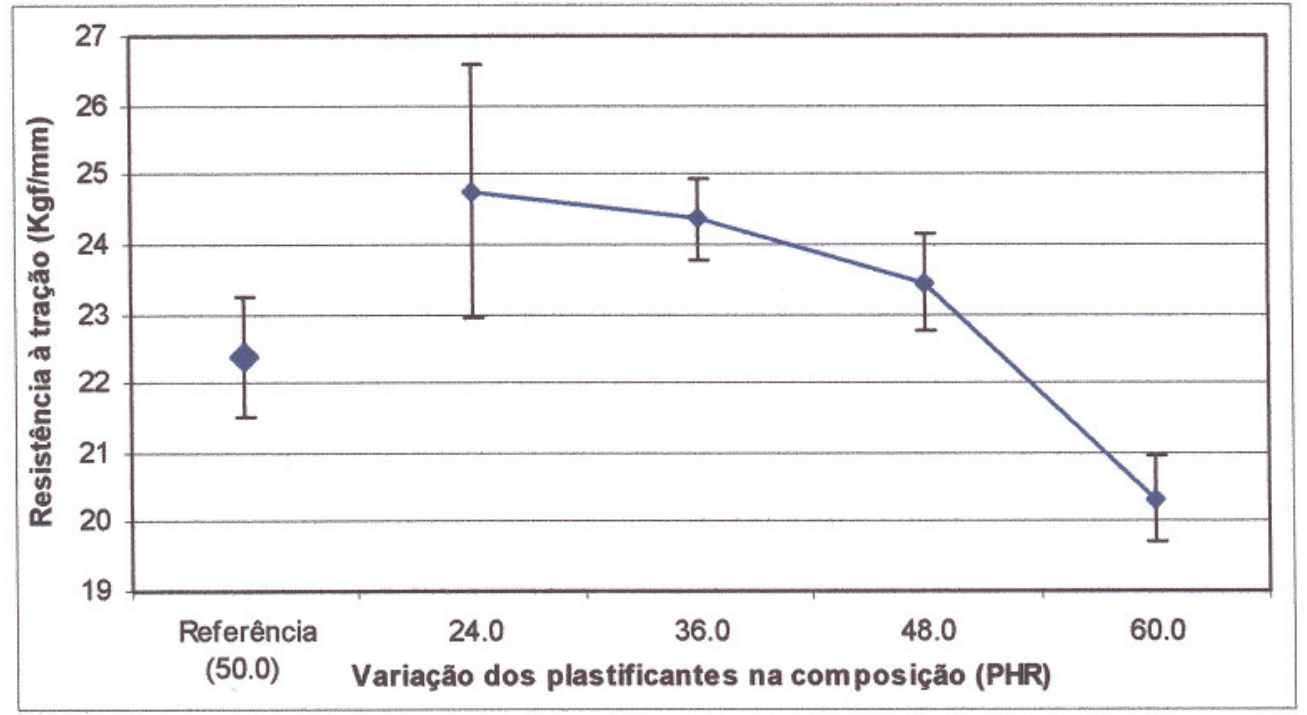

Figura 43 - Gráfico dos valores de resistência à tração $(\mathrm{Kgf} / \mathrm{mm})$ em relação à variação dos plastificantes na composição (PHR).

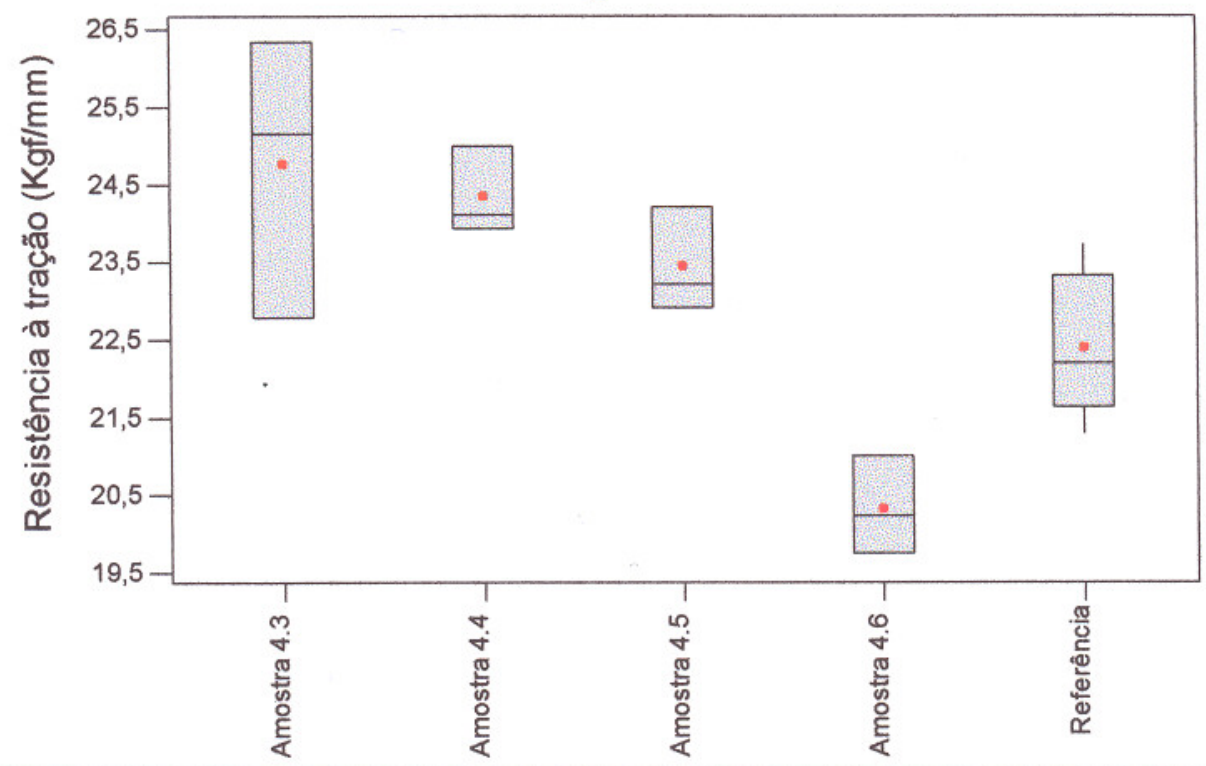

Figura 44 - Gráfico "Boxplot" da resistência à tração (Kgf/mm) versus a variação dos plastificantes (Amostra 4.3 a Amostra 4.6 e Referência). 
A variação da quantidade dos plastificantes também mostrou conforme a Figura 45, uma forte influência nos valores de alongamento. À medida que se aumenta a quantidade de plastificante se observa o aumento dos valores de alongamento. O valor de variância foi de 0,000 e foram observados grupos distintos de variação no gráfico "Boxplot" mostrado na Figura 46.

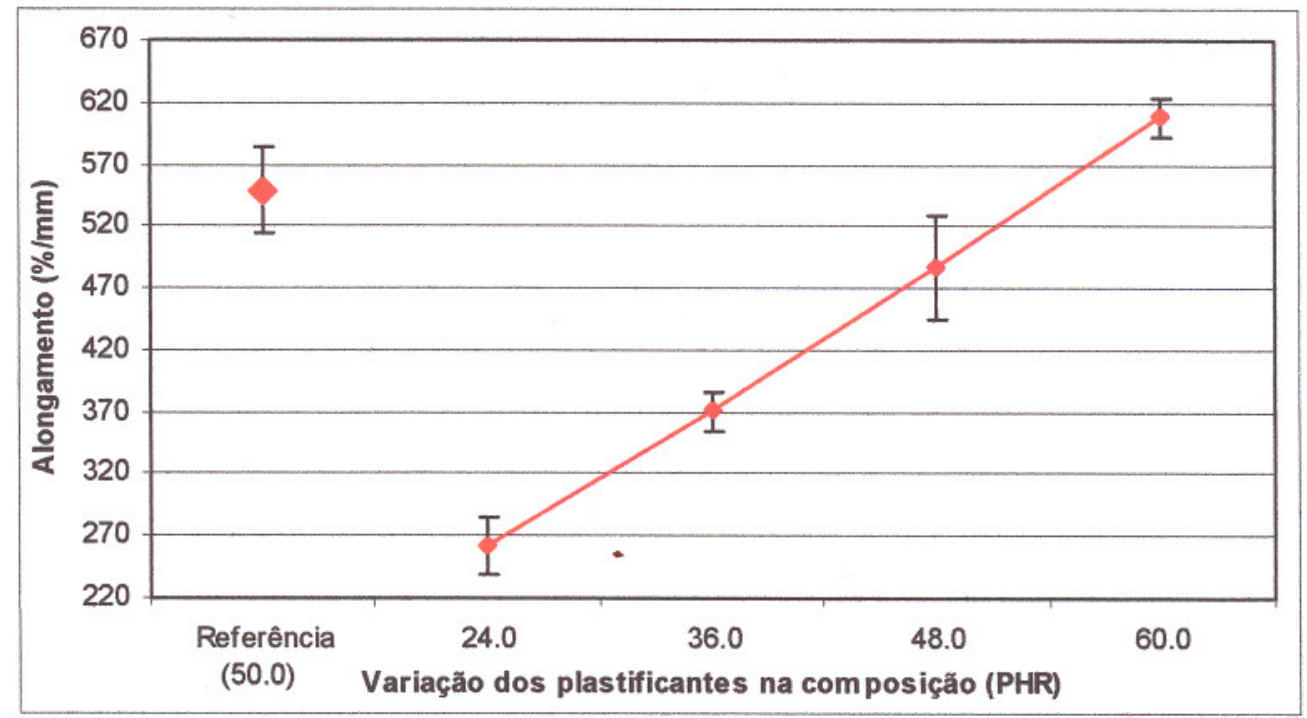

Figura 45 - Gráfico dos valores de alongamento $(\% / \mathrm{mm})$ em relação à variação dos plastificantes na composição (PHR). 


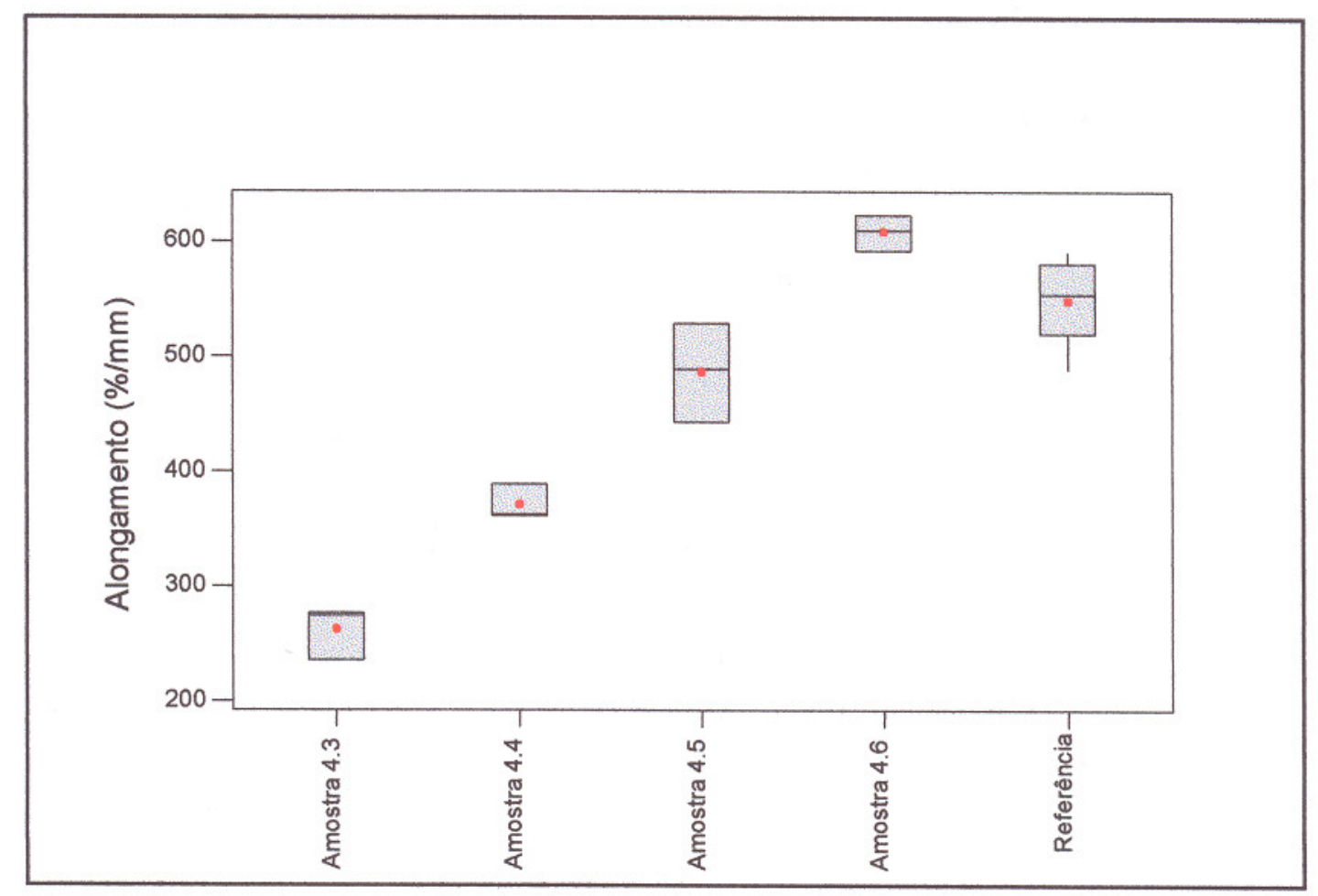

Figura 46 - Gráfico "Boxplot" do alongamento $(\% / \mathrm{mm})$ versus a variação dos plastificantes (Amostra 4.3 a Amostra 4.6 e Referência).

As tendências observadas da.diminuição da resistência à tração e do aumento do alongamento a medida que foi aumentada a quantidade de plastificantes estão de acordo com a literatura ${ }^{(10)}$.

\subsection{MEDIDAS ELÉTRICAS}

\subsubsection{Rigidez Dielétrica}

Durante os ensaios de rigidez dielétrica foram feitas leituras da temperatura e umidade da sala de teste. Estes valores e os resultados das medidas dos ensaios estão apresentados no Anexo C.

A análise dos resultados obtidos para a rigidez dielétrica em relação ao aumento da quantidade de cada material (pigmento, carga, modificador de 
impacto e plastificantes) conforme as Figuras 47, 49, 51 e 53 não mostrou qualquer tendência de comportamento. As análises da variância resultaram nos valores de 0,190 (variação do pigmento), 0,409 (variação da carga), 0,722 (variação do modificador de impacto), 0,300 (variação dos plastificantes). Isto significa que as quantidades destes materiais na composição, nas faixas escolhidas para este trabalho, não influenciaram os valores de rigidez dielétrica. Observando as Figuras 48, 50, 52 e 54, os gráficos "Boxplot" indicaram que todos os subgrupos das amostras estão na mesma faixa de variação.

Não foi possível realizar os ensaios para as Amostras 4.1 e 4.2 devido à impossibilidade de obter a espessura mínima requerida para os corpos de prova destas amostras, ultrapassando o limite máximo de operação do equipamento de medição da tensão disruptiva.

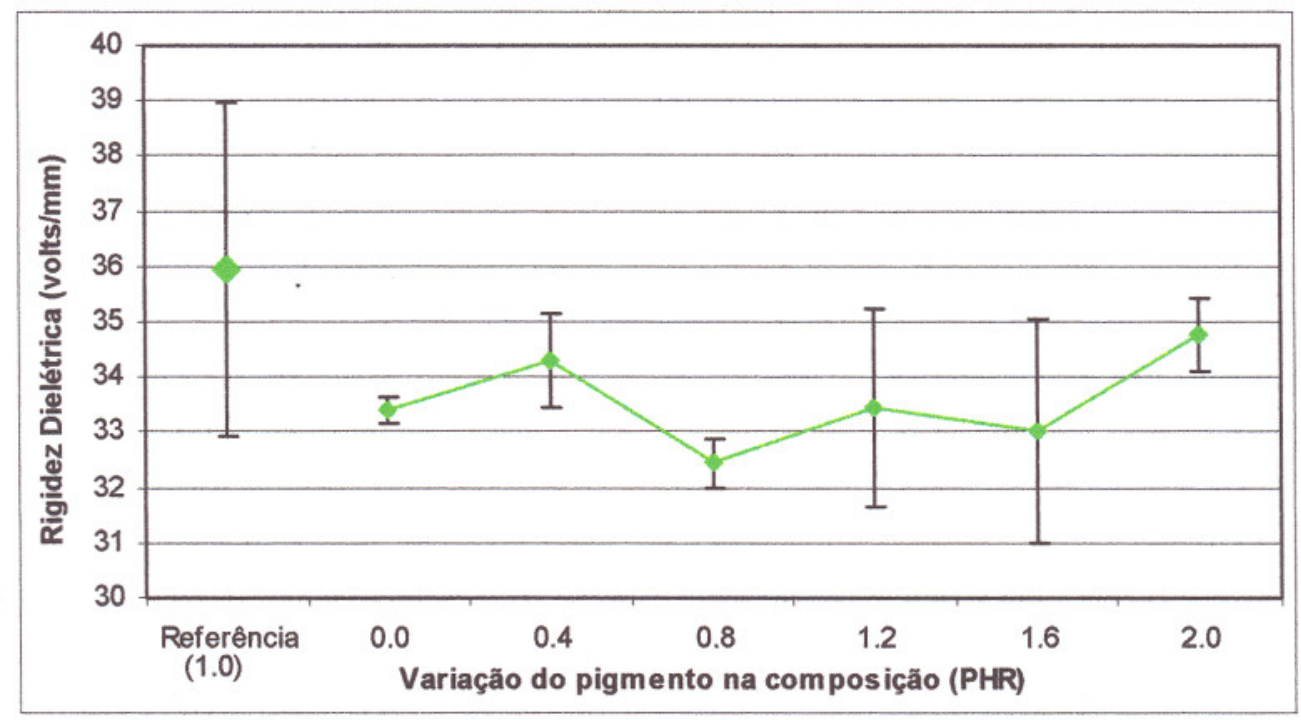

Figura 47 - Gráfico dos valores de rigidez dielétrica (volts $/ \mathrm{mm}$ ) em relação à variação do pigmento na composição (PHR). 


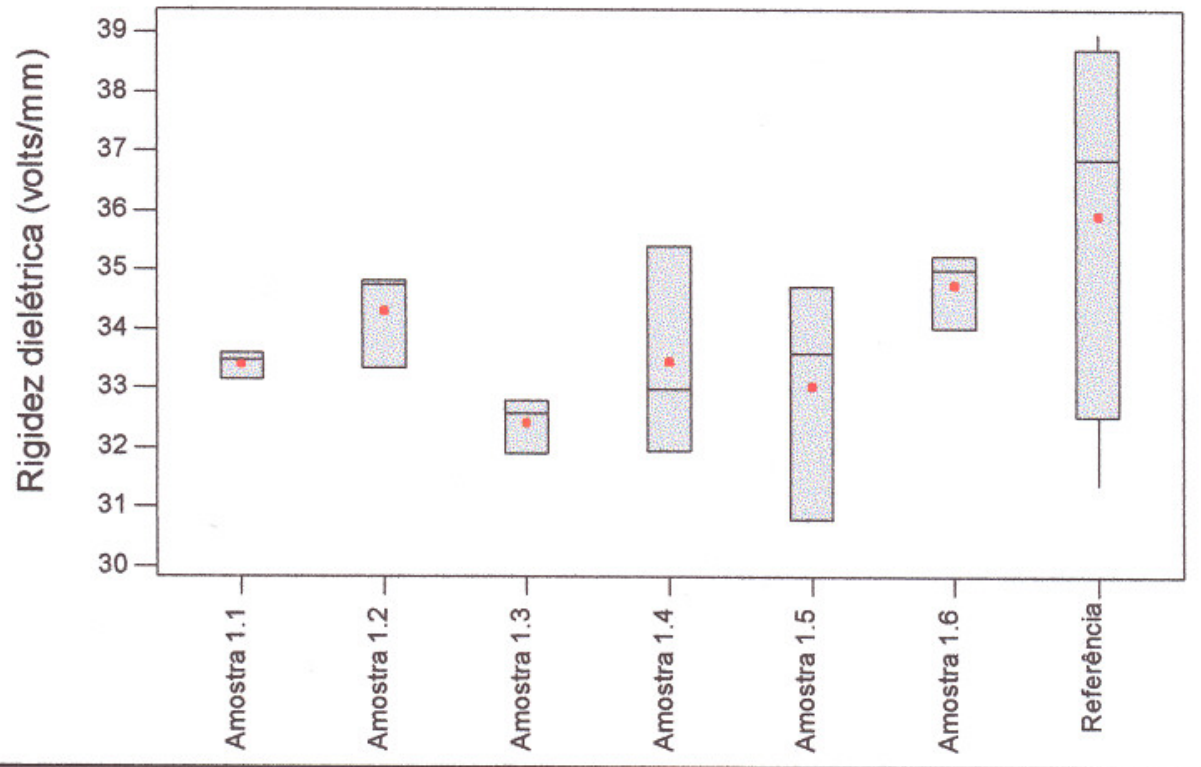

Figura 48 - Gráfico "Boxplot" da rigidez dielétrica (volts $/ \mathrm{mm}$ ) versus a variação do pigmento (Amostra 1.1 a Amostra 1.6 e Referência).

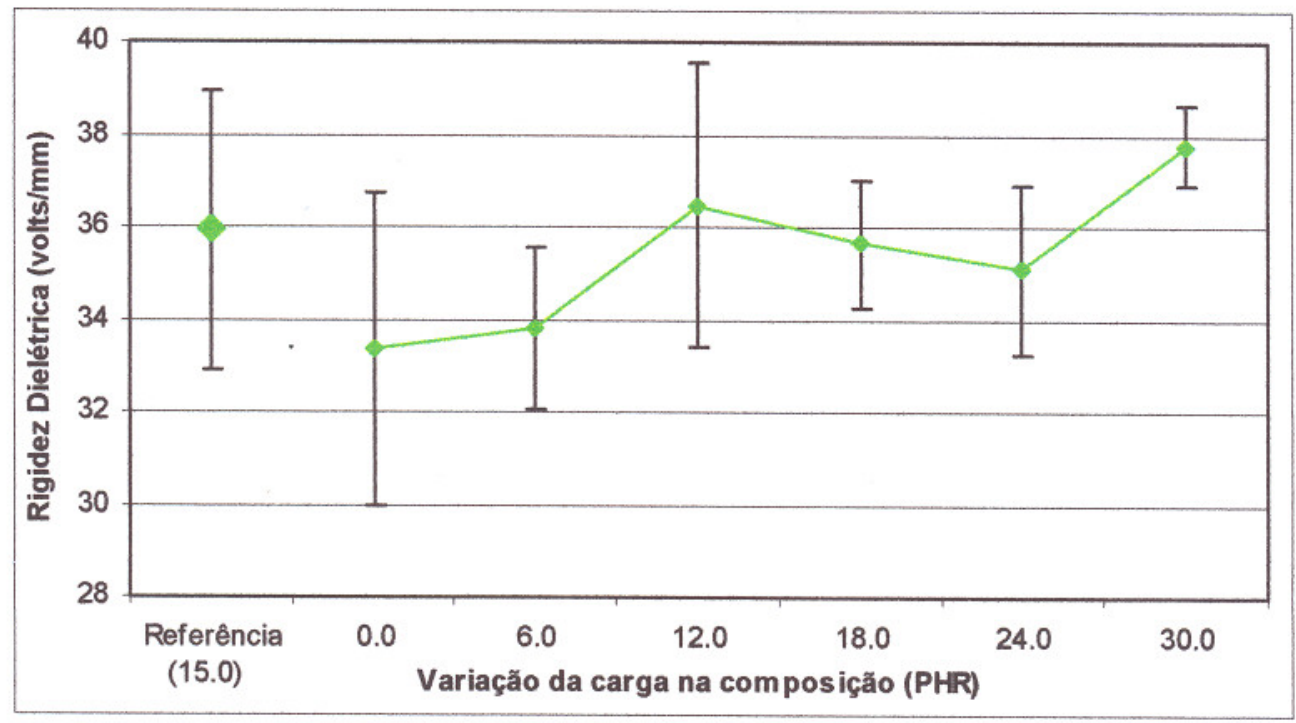

Figura 49 - Gráfico dos valores de rigidez dielétrica (volts/mm) em relação à variação da carga na composição (PHR). 


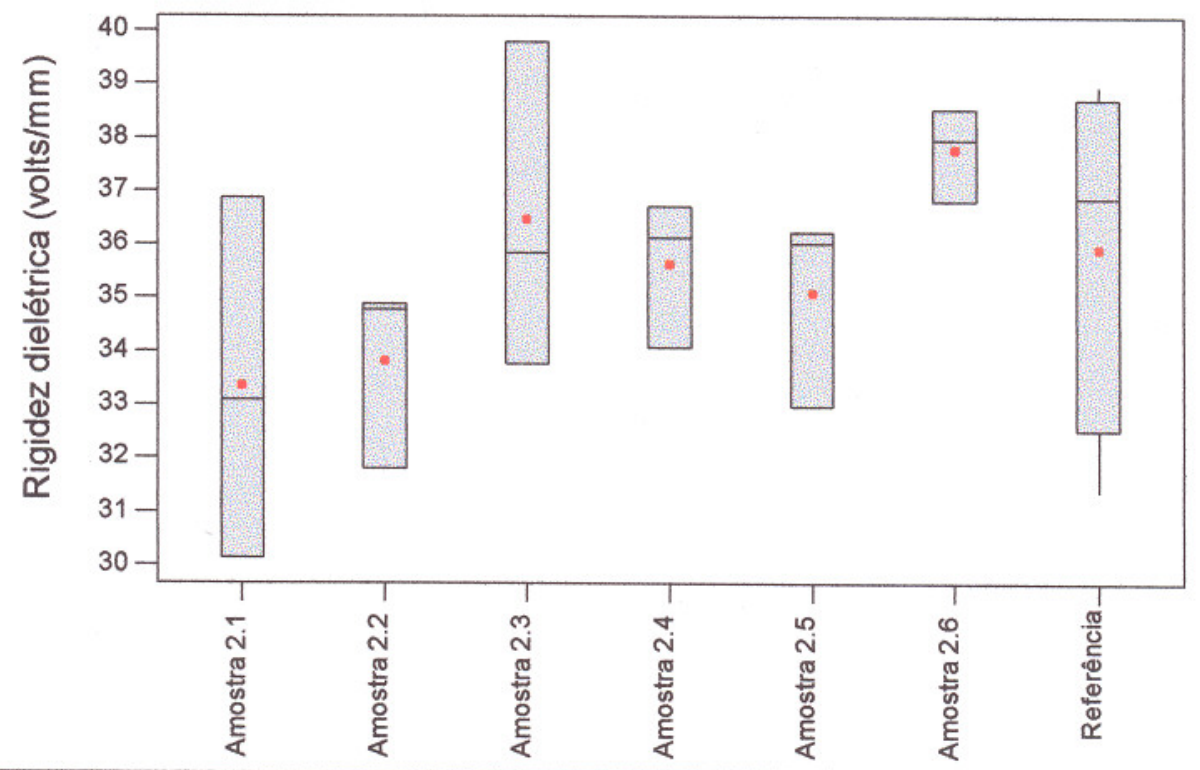

Figura 50 - Gráfico "Boxplot" da rigidez dielétrica (volts $/ \mathrm{mm}$ ) versus a variação da carga (Amostra 2.1 a Amostra 2.6 e Referência).

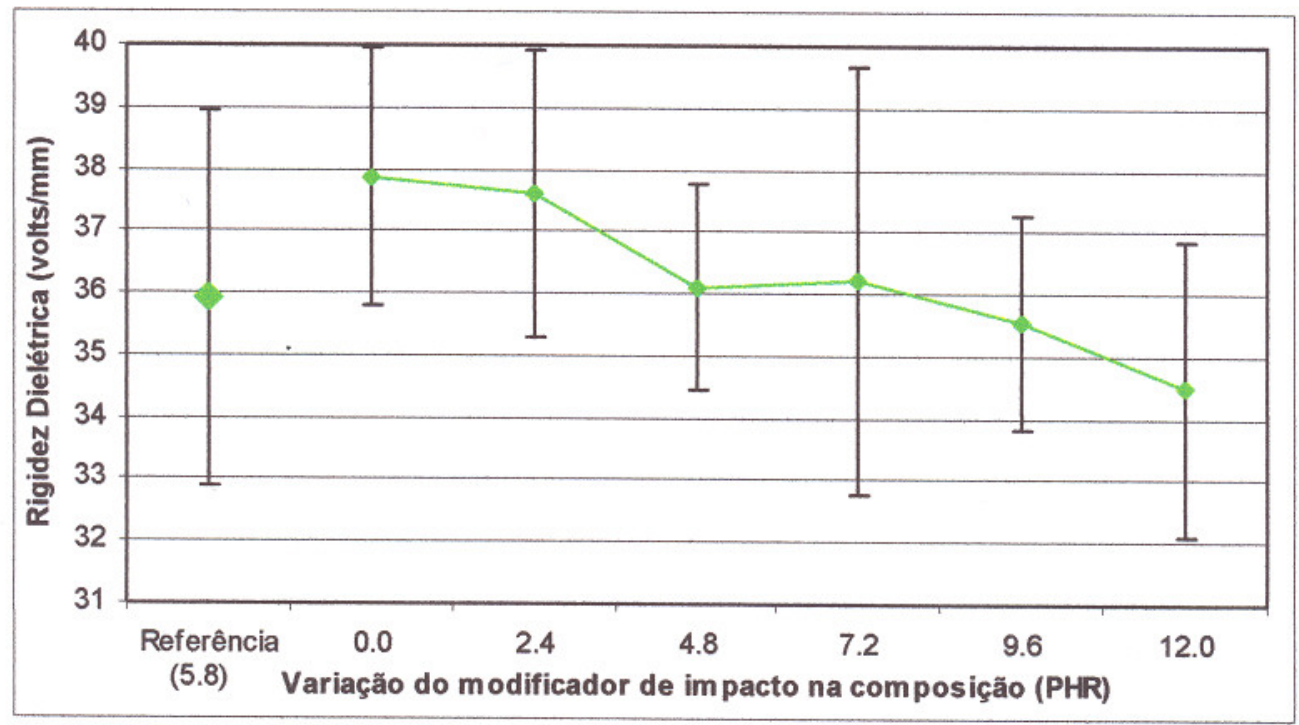

Figura 51 - Gráfico dos valores de rigidez dielétrica (volts $/ \mathrm{mm}$ ) em relação à variação do modificador de impacto na composição (PHR). 


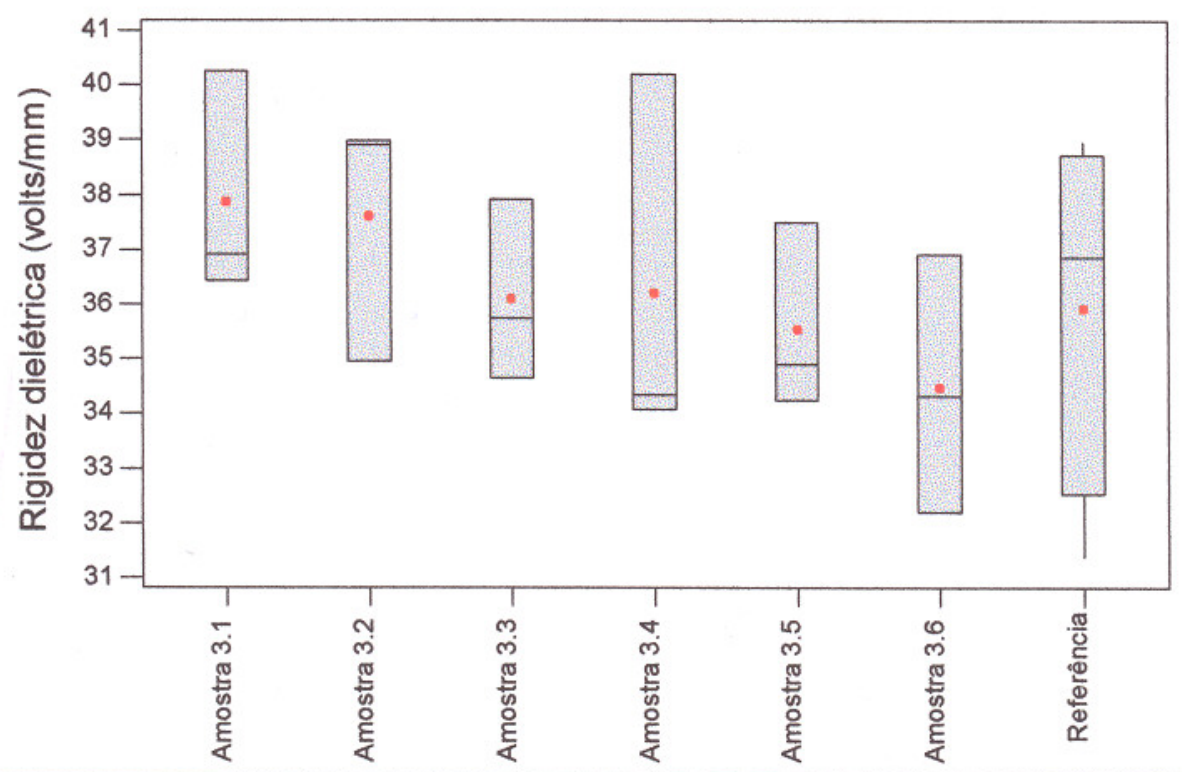

Figura 52 - Gráfico "Boxplot" da rigidez dielétrica (volts $/ \mathrm{mm}$ ) versus a variação do modificador de impacto (Amostra 3.1 a Amostra 3.6 e Referência).

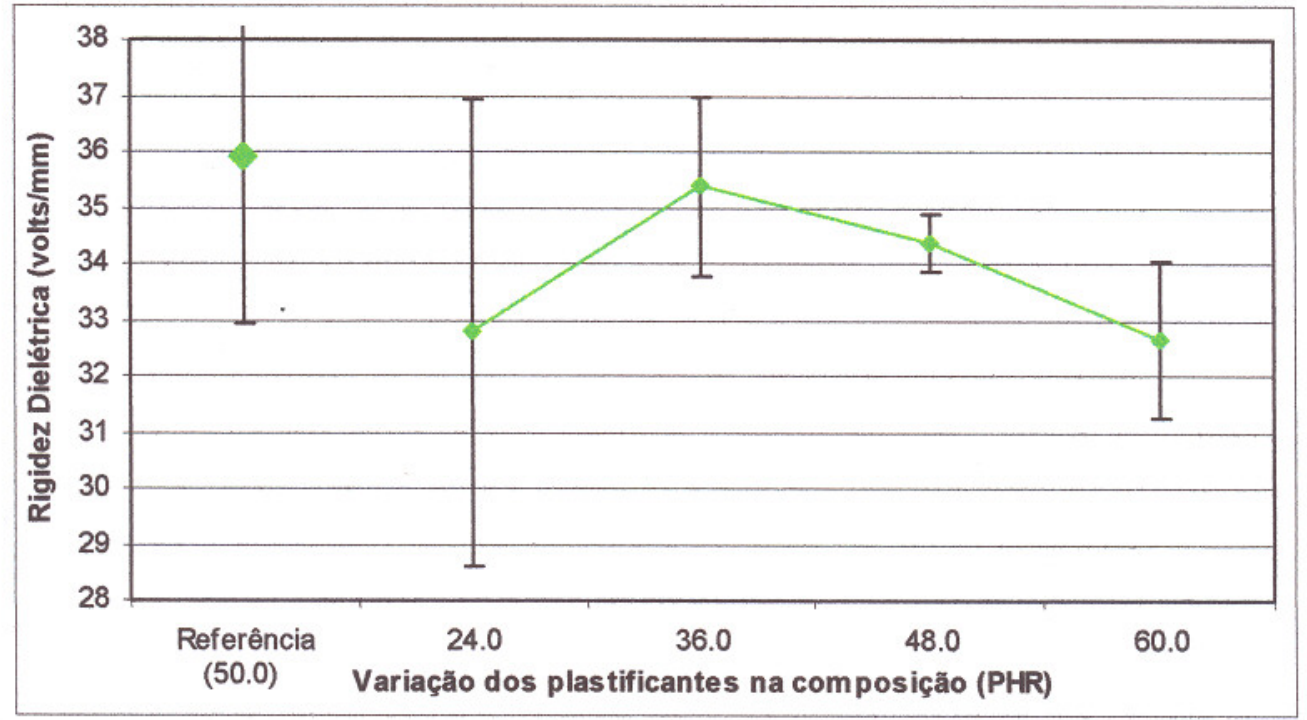

Figura 53 - Gráfico dos valores de rigidez dielétrica (volts $/ \mathrm{mm})$ em relação à variação dos plastificantes de impacto na composição (PHR). 


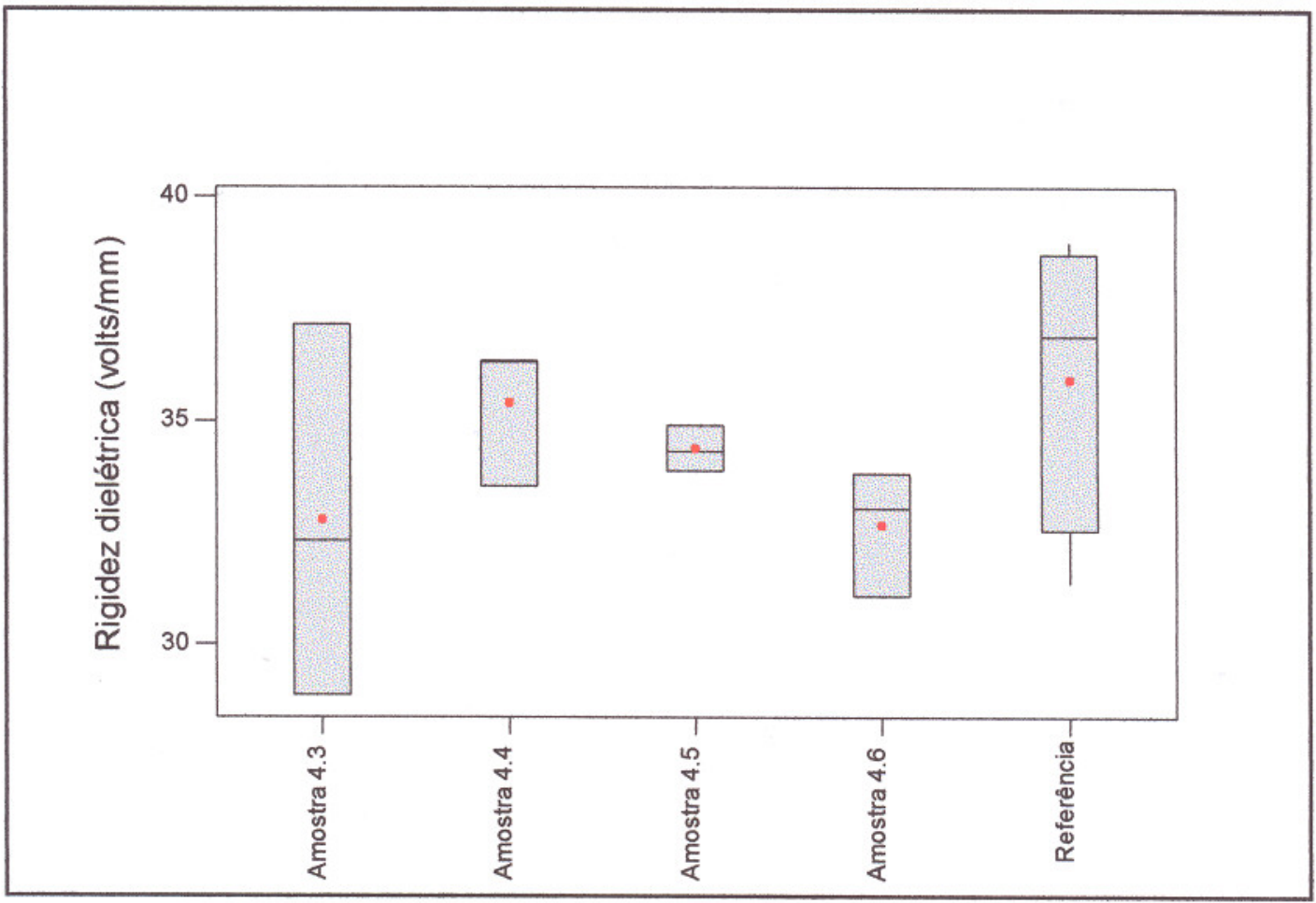

Figura 54 - Gráfico "Boxplot" da rigidez dielétrica (volts $/ \mathrm{mm}$ ) versus a variação dos plastificantes (Amostra 4.3 a Amostra 4.6 e Referência). 


\section{CONCLUSÕES}

O trabalho desenvolvido nesta dissertação de mestrado possibilitou a obtenção de um método de caracterização de filmes de PVC em escala laboratorial para aplicação industrial. Poucos estudos são encontrados na literatura sobre a caracterização de compostos de PVC plastificado com a finalidade de fabricação de produtos com aplicação para isolação elétrica, e este trabalho permitiu registrar parte do conhecimento tácito encontrado na prática industrial.

A faixa escolhida para a variação da quantidade de pigmento (negro de fumo) na composição não mostrou ter influência nas propriedades térmicas, mecânicas e elétricas. Para filmes com aplicação de isolação elétrica, geralmente este material é utilizado somente para conferir a cor no material. Considerando as análises realizadas em amostras com o dobro da quantidade da formulação referencial, não foi evidenciada variação das propriedades elétricas do material.

As variações das composições em relação a carga e ao modificador de impacto não mostraram influências nas propriedades térmicas e elétricas do material, porém o aumento das quantidades destes materiais levaram à diminuição das propriedades mecânicas. Através dos resultados obtidos pode-se concluir que é de extrema importância a dispersão homogênea 
destes materiais na rede polimérica durante o processamento, para minimizar a variabilidade destas propriedades.

O aumento da quantidade de plastificantes na composição mostrou ser o principal fator de influência nas propriedades estudadas do material, com exceção das propriedades elétricas. Em relação às propriedades térmicas, quanto maior a proporção de plastificantes, menores são as temperaturas onde ocorrem as mudanças de fase e propriedades mecânicas, e aumenta-se a estabilidade térmica do material. Isto propicia maior flexibilidade nos ajustes dos parâmetros de processamento do material, o que pode evitar o início prematuro da cadeia de degradação dos compostos. O aumento da quantidade de plastificantes também influencia nas propriedades mecânicas do material, levando à diminuição da resistência à tração e ao aumento do alongamento, o que também minimiza ajustes no processamento para atingir estas propriedades.

Finalmente, este trabalho mostrou que os resultados obtidos em escala de laboratório podem ser comparados e correlacionados com resultados obtidos em escala industrial, pois as conclusões levantadas já foram identificadas na prática industrial. 


\section{SUGESTÕES PARA TRABALHOS FUTUROS}

Como sugestão para continuidade deste trabalho, destacam-se os seguintes estudos futuros:

- Estudo da variação de outros materiais da composição, como estabilizante térmico, lubrificante etc.

- Análises das propriedades térmicas e mecânicas das amostras envelhecidas por processos natural e acelerado.

- Estudo da aplicação de outras blendas em processamento de filmes flexíveis e isolação elétrica.

- Estudo dos mecanismos de migração em compostos de PVC plastificados.

- Correlação de resultados de análises de DMA com as propriedades de resistência mecânica, cristalinidade e homogeneidade da mistura. 


\section{ANEXOS}

ANEXO A - Parâmetros de ajuste da máquina de tração Kratos para filmes de PVC.

\begin{tabular}{|l|l|}
\hline Unidade de medida & $\mathrm{Kgf} / \mathrm{mm}$ \\
\hline Comprimento do corpo de prova & $50 \mathrm{~mm}$ \\
\hline Área variável & $\mathrm{NÃO}$ \\
\hline Largura corpo de prova & $10 \mathrm{~mm}$ \\
\hline Espessura corpo de prova & $0.780 \mathrm{~mm}$ (média) \\
\hline Diâmetro corpo de prova & - \\
\hline Área transversal corpo de prova & - \\
\hline Carga máxima prevista & $15 \mathrm{Kgf}$ \\
\hline Deslocamento máximo previsto & $800 \mathrm{~mm}$ \\
\hline Pré-carga & $1 \%$ \\
\hline Velocidade de ensaio & $300 \mathrm{~mm} / \mathrm{min}$ \\
\hline Ruptura (\% carga máxima prevista) & $2 \%$ \\
\hline Extensómetro & $\mathrm{NÃO}$ \\
\hline Retorno automático & $\mathrm{SIM}$ \\
\hline Identificação & $\mathrm{SIM}$ \\
\hline
\end{tabular}


ANEXO B - Leituras e medidas dos ensaios de resistência à tração e alongamento.

\begin{tabular}{|c|c|c|c|c|c|c|c|}
\hline Amostra & $\begin{array}{c}T_{\text {ambiente }} \\
\left({ }^{\circ} \mathrm{C}\right)\end{array}$ & $\begin{array}{c}\text { Umidade } \\
\text { (UR) }\end{array}$ & $\begin{array}{c}\text { Espessura } \\
(\mathrm{mm})\end{array}$ & $\begin{array}{c}\text { Resistencia } \\
\text { a traçăo } \\
\text { (Kg) }\end{array}$ & $\begin{array}{c}\text { Resistencia } \\
\text { a traçăo } \\
\text { (Kgf/mm) }\end{array}$ & $\begin{array}{c}\text { Alongamento } \\
(\%)\end{array}$ & $\begin{array}{c}\text { Alongamento } \\
(\% / \mathrm{mm})\end{array}$ \\
\hline Referência & 23,0 & 48 & 0,869 & 18,90 & 21,75 & 513,80 & 591,25 \\
\hline Referência & 23,2 & 50 & 0,884 & 19,03 & 21,52 & 513,60 & 581,00 \\
\hline Referência & 23,5 & 52 & 0,891 & 19,78 & 22,19 & 505,54 & 567,38 \\
\hline Referéncia & 23,5 & 52 & 0,858 & 18,85 & 21,97 & 475,64 & 554,36 \\
\hline Referência & 23,3 & 50 & 0,836 & 18,75 & 22,43 & 486,04 & 581,39 \\
\hline Referência & 23,1 & 48 & 0,823 & 17,53 & 21,29 & 440,50 & 535,24 \\
\hline Referência & 22,8 & 48 & 0,895 & 21,23 & 23,72 & 462,10 & 516,31 \\
\hline Referência & 22,6 & 49 & 0,908 & 21,10 & 23,24 & 443,84 & 488,81 \\
\hline Referéncia & 22,5 & 50 & 0,908 & 21,25 & 23,40 & 474,90 & 523,02 \\
\hline Amostra 1.1 & 22,4 & 51 & 0,816 & 19,03 & 23,31 & 466,48 & 571,67 \\
\hline Amostra 1.1 & 22,3 & 52 & 0,843 & 18,33 & 21,74 & 446,16 & 529,25 \\
\hline Amostra 1.1 & 22,2 & 51 & 0,829 & 18,23 & 21,98 & 440,68 & 531,58 \\
\hline Amostra 1.2 & 22,1 & 50 & 0,996 & 21,45 & 21,54 & 439,90 & 441,67 \\
\hline Amostra 1.2 & 22,1 & 49 & 0,998 & 22,90 & 22,95 & 534,34 & 535,41 \\
\hline Amostra 1.2 & 22,2 & 48 & 1,002 & 21,75 & 21,71 & 485,86 & 484,89 \\
\hline Amostra 1.3 & 22,6 & 51 & 0,924 & 20,93 & 22,65 & 525,46 & 568,68 \\
\hline Amostra 1.3 & 22,9 & 52 & 0,928 & 20,45 & 22,04 & 502,62 & 541,62 \\
\hline Amostra 1.3 & 23,0 & 50 & 0,940 & 20,53 & 21,84 & 484,58 & 515,51 \\
\hline Amostra 1.4 & 23,2 & 48 & 0,866 & 19,25 & 22,23 & 470,04 & 542,77 \\
\hline Amostra 1.4 & 23,3 & 48 & 0,886 & 20,38 & 23,00 & 493,84 & 557,38 \\
\hline Amostra 1.4 & 23,3 & 49 & 0,900 & 19,80 & 22,00 & 451,38 & 501,53 \\
\hline Amostra 1.5 & 23,3 & 50 & 0,960 & 21,08 & 21,96 & 449,46 & 468,19 \\
\hline Amostra 1.5 & 23,2 & 51 & 0,965 & 21,08 & 21,84 & 461,56 & 478,30 \\
\hline Amostra 1.5 & 23,0 & 51 & 0,962 & 23,23 & 24,15 & 530,98 & 551,95 \\
\hline Amostra 1.6 & 22,9 & 52 & 0,916 & 21,38 & 23,34 & 482,90 & 527,18 \\
\hline Amostra 1.6 & 22,8 & 52 & 0,928 & 22,38 & 24,11 & 493,88 & 532,20 \\
\hline Amostra 1.6 & 22,7 & 52 & 0,948 & 22,33 & 23,55 & 512,78 & 540,91 \\
\hline Amostra 2.1 & 21,8 & 55 & 0,880 & 21,20 & 24,09 & 537,98 & 611,34 \\
\hline Amostra 2.1 & 21,8 & 55 & 0,853 & 20,56 & 24,10 & 506,36 & 593,62 \\
\hline Amostra 2.1 & 21,9 & 55 & 0,842 & 19,77 & 23,48 & 475,56 & 564,80 \\
\hline Amostra 2.2 & 21,9 & 55 & 0,907 & 22,15 & 24,42 & 523,28 & 576,93 \\
\hline Amostra 2.2 & 21,9 & 55 & 0,887 & 21,80 & 24,58 & 512,90 & 578,24 \\
\hline Amostra 2.2 & 21,8 & 55 & 0,906 & 21,68 & 23,92 & 521,78 & 575,92 \\
\hline Amostra 2.3 & 21,7 & 55 & 0,896 & 20,55 & 22,94 & 510,02 & 569,22 \\
\hline Amostra 2.3 & 21,7 & 55 & 0,891 & 19,63 & 22,03 & 479,90 & 538,61 \\
\hline Amostra 2.3 & 21,7 & 55 & 0,887 & 19,05 & 21,48 & 448,38 & 505,50 \\
\hline Amostra 2.4 & 22,0 & 55 & 0,895 & 18,98 & 21,21 & 444,36 & 496,49 \\
\hline Amostra 2.4 & 22,0 & 55 & 0,911 & 20,02 & 21,98 & 472,76 & 518,95 \\
\hline Amostra 2.4 & 22,0 & 55 & 0,931 & 22,18 & 23,82 & 531,28 & 570,66 \\
\hline Amostra 2.5 & 21,9 & 54 & 0,941 & 20,98 & 22,29 & 482,32 & 512,56 \\
\hline Amostra 2.5 & 21,9 & 52 & 0,935 & 20,28 & 21,68 & 447,98 & 479,12 \\
\hline Amostra 2.5 & 21,8 & 51 & 0,946 & 19,68 & 20,80 & 421,48 & 445,54 \\
\hline Amostra 2.6 & 21,7 & 50 & 0,898 & 18,70 & 20,82 & 449,82 & 500,91 \\
\hline Amostra 2.6 & 21,7 & 52 & 0,899 & 19,40 & 21,58 & 477,12 & 530,72 \\
\hline Amostra 2.6 & 21,7 & 53 & 0,898 & 19,00 & 21,16 & 460,54 & 512,85 \\
\hline
\end{tabular}


ANEXO B - Continuação.

\begin{tabular}{|c|c|c|c|c|c|c|c|}
\hline Amostra & $\begin{array}{c}T_{\text {ambientice }} \\
\left({ }^{\circ} \mathrm{C}\right)\end{array}$ & $\begin{array}{l}\text { Umidade } \\
\text { (UR) }\end{array}$ & $\begin{array}{c}\text { Espessura } \\
(\mathrm{mm})\end{array}$ & $\begin{array}{c}\text { Resistência } \\
\text { a tração } \\
\text { (Kgf) }\end{array}$ & $\begin{array}{c}\text { Resisténcia } \\
\text { à tração } \\
(\mathrm{Kgt} / \mathrm{mm})\end{array}$ & $\begin{array}{l}\text { Alongamento } \\
\text { (\%) }\end{array}$ & $\begin{array}{c}\text { Alongamento } \\
(\% / \mathrm{mm})\end{array}$ \\
\hline Amostra 3.1 & 21,7 & 54 & 0,937 & 22,60 & 24,12 & 490,46 & 523,44 \\
\hline Amostra 3.1 & 21,7 & 54 & 0,940 & 23,08 & 24,55 & 510,26 & 542,83 \\
\hline Amostra 3.1 & 21,7 & 55 & 0,944 & 21,70 & 22,99 & 470,10 & 497,99 \\
\hline Amostra 3.2 & 21,8 & 55 & 0,882 & 19,93 & 22,60 & 487,84 & 553,11 \\
\hline Amostra 3.2 & 21,9 & 55 & 0,888 & 19,85 & 22,35 & 482,06 & 542,86 \\
\hline Amostra 3.2 & 21,9 & 55 & 0,872 & 19,52 & 22,39 & 478,62 & 548,88 \\
\hline Amostra 3.3 & 22,0 & 53 & 0,972 & 20,33 & 20,92 & 452,58 & 465,62 \\
\hline Amostra 3.3 & 22,0 & 51 & 0,970 & 22,00 & 22,68 & 505,84 & 521,48 \\
\hline Amostra 3.3 & 22,1 & 51 & 0,975 & 22,18 & 22,75 & 529,12 & 542,69 \\
\hline Amostra 3.4 & 22,1 & 52 & 1,000 & 22,30 & 22,30 & 513,04 & 513,04 \\
\hline Amostra 3.4 & 22,2 & 53 & 0,995 & 20,88 & 20,98 & 485,62 & 488,06 \\
\hline Amostra 3.4 & 22,3 & 54 & 1,007 & 19,58 & 19,44 & 431,28 & 428,28 \\
\hline Amostra 3.5 & 22,4 & 54 & 1,002 & 21,48 & 21,43 & 512,98 & 511,96 \\
\hline Amostra 3.5 & 22,4 & 55 & 0,995 & 22,10 & 22,21 & 528,40 & 531,06 \\
\hline Amostra 3.5 & 22,5 & 55 & 0,967 & 19,00 & 19,65 & 427,24 & 441,82 \\
\hline Amostra 3.6 & 22,5 & 55 & 0,921 & 20,38 & 22,12 & 503,38 & 546,56 \\
\hline Amostra 3.6 & 22,3 & 55 & 0,932 & 21,15 & 22,69 & 537,64 & 576,87 \\
\hline Amostra 3.6 & 22,2 & 55 & 0,920 & 20,25 & 22,01 & 492,12 & 534,91 \\
\hline Amostra 4.3 & 22,4 & 54 & 1,280 & 29,18 & 22,79 & 351,14 & 274,33 \\
\hline Amostra 4.3 & 22,5 & 54 & 1,280 & 32,20 & 25,16 & 300,90 & 235,08 \\
\hline Amostra 4.3 & 22,6 & 55 & 1,340 & 35,30 & 26,34 & 370,54 & 276,52 \\
\hline Amostra 4.4 & 22,6 & 55 & 1,120 & 28,00 & 25,00 & 404,96 & 361,57 \\
\hline Amostra 4.4 & 22,5 & 55 & 1,150 & 27,53 & 23,93 & 415,94 & 361,69 \\
\hline Amostra 4.4 & 22,5 & 55 & 1,170 & 28,23 & 24,12 & 455,28 & 389,13 \\
\hline Amostra 4.5 & 22,4 & 55 & 0,922 & 22,33 & 24,21 & 487,82 & 529,09 \\
\hline Amostra 4.5 & 22,2 & 55 & 0,948 & 21,73 & 22,92 & 462,86 & 488,25 \\
\hline Amostra 4.5 & 22,2 & 55 & 0,955 & 22,18 & 23,22 & 423,70 & 443,66 \\
\hline Amostra 4.6 & 22,0 & 55 & 0,832 & 17,48 & 21,00 & 507,36 & 609,81 \\
\hline Amostra 4.6 & 21,9 & 55 & 0,829 & 16,78 & 20,24 & 517,04 & 623,69 \\
\hline Amostra 4.6 & 21,8 & 54 & 0,824 & 16,28 & 19,75 & 488,24 & 592,52 \\
\hline
\end{tabular}


ANEXO C - Leituras e medidas dos ensaios de tensão disruptiva.

\begin{tabular}{|c|c|c|c|c|c|}
\hline Amostra & $\begin{array}{c}T_{\text {ambiente }} \\
\left({ }^{\circ} \mathrm{C}\right)\end{array}$ & $\begin{array}{l}\text { Umidade } \\
\text { (UR) }\end{array}$ & $\begin{array}{c}\text { Espessura } \\
\quad(\mathrm{mm})\end{array}$ & $\begin{array}{l}\text { Tensão } \\
\text { disruptiva } \\
\text { (volts) }\end{array}$ & $\begin{array}{c}\text { Rigidez } \\
\text { dielétrica } \\
\text { (volts } / \mathrm{mm} \text { ) }\end{array}$ \\
\hline Referência & 21,1 & 51 & 0,553 & 21,50 & 38,88 \\
\hline Referência & 21,1 & 53 & 0,598 & 22,05 & 36,87 \\
\hline Referência & 21,1 & 54 & 0,494 & 19,05 & 38,56 \\
\hline Referência & 21,2 & 52 & 0,503 & 19,60 & 38,97 \\
\hline Referência & 21,2 & 51 & 0,565 & 21,30 & 37,70 \\
\hline Referência & 21,1 & 50 & 0,615 & 22,10 & 35,93 \\
\hline Referência & 21,1 & 55 & 0,630 & 20,70 & 32,86 \\
\hline Referência & 21,1 & 55 & 0,576 & 18,55 & 32,20 \\
\hline Referência & 21,2 & 54 & 0,682 & 21,40 & 31,38 \\
\hline Amostra 1.1 & 21,1 & 52 & 0,620 & 20,55 & 33,15 \\
\hline Amostra 1.1 & 21,1 & 53 & 0,561 & 18,85 & 33,60 \\
\hline Amostra 1.1 & 21,1 & 55 & 0,581 & 19,45 & 33,48 \\
\hline Amostra 1.2 & 21,1 & 51 & 0,537 & 18,70 & 34,82 \\
\hline Amostra 1.2 & 21,1 & 50 & 0,541 & 18,80 & 34,75 \\
\hline Amostra 1.2 & 21,1 & 50 & 0,570 & 19,00 & 33,33 \\
\hline Amostra 1.3 & 21,1 & 55 & 0,617 & 20,10 & 32,58 \\
\hline Amostra 1.3 & 21,1 & 54 & 0,658 & 21,00 & 31,91 \\
\hline Amostra 1.3 & 21,1 & 52 & 0,625 & 20,50 & 32,80 \\
\hline Amostra 1.4 & 21,0 & 54 & 0,591 & 19,50 & 32,99 \\
\hline Amostra 1.4 & 21,1 & 55 & 0,648 & 20,70 & 31,94 \\
\hline Amostra 1.4 & 21,1 & 55 & 0,497 & 17,60 & 35,41 \\
\hline Amostra 1.5 & 21,0 & 50 & 0,708 & 21,80 & 30,79 \\
\hline Amostra 1.5 & 21,0 & 51 & 0,540 & 18,75 & 34,72 \\
\hline Amostra 1.5 & 21,0 & 52 & 0,564 & 18,95 & 33,60 \\
\hline Amostra 1.6 & 21,1 & 53 & 0,497 & 17,40 & 35,01 \\
\hline Amostra 1.6 & 21,1 & 52 & 0,488 & 17,20 & 35,25 \\
\hline Amostra 1.6 & 21,1 & 51 & 0,513 & 17,45 & 34,02 \\
\hline Amostra 2.1 & 21,1 & 55 & 0,388 & 14,30 & 36,86 \\
\hline Amostra 2.1 & 21,1 & 55 & 0,499 & 16,50 & 33,07 \\
\hline Amostra 2.1 & 21,1 & 54 & 0,619 & 18,65 & 30,13 \\
\hline Amostra 2.2 & 21,0 & 53 & 0,489 & 17,00 & 34,76 \\
\hline Amostra 2.2 & 21,0 & 54 & 0,588 & 18,70 & 31,80 \\
\hline Amostra 2.2 & 21,0 & 55 & 0,476 & 16,60 & 34,87 \\
\hline Amostra 2.3 & 21,0 & 50 & 0,466 & 16,70 & 35,84 \\
\hline Amostra 2.3 & 21,0 & 50 & 0,382 & 15,20 & 39,79 \\
\hline Amostra 2.3 & 21,0 & 51 & 0,508 & 17,15 & 33,76 \\
\hline Amostra 2.4 & 21,1 & 54 & 0,485 & 17,80 & 36,70 \\
\hline Amostra 2.4 & 21,1 & 52 & 0,521 & 17,75 & 34,07 \\
\hline Amostra 2.4 & 21,0 & 51 & 0,494 & 17,85 & 36,13 \\
\hline Amostra 2.5 & 21,0 & 54 & 0,512 & 18,55 & 36,23 \\
\hline Amostra 2.5 & 21,0 & 55 & 0,505 & 18,20 & 36,04 \\
\hline Amostra 2.5 & 21,1 & 55 & 0,640 & 21,10 & 32,97 \\
\hline Amostra 2.6 & 21,0 & 51 & 0,490 & 18,60 & 37,96 \\
\hline Amostra 2.6 & 21,0 & 52 & 0,480 & 18,50 & 38,54 \\
\hline Amostra 2.6 & 21,0 & 53 & 0,527 & 19,40 & 36,81 \\
\hline
\end{tabular}


ANEXO C - Continuação.

\begin{tabular}{|c|c|c|c|c|c|}
\hline Amostra & $\begin{array}{c}T_{\text {ambiente }} \\
\left({ }^{\circ} \mathrm{C}\right)\end{array}$ & $\begin{array}{c}\text { Umidade } \\
(\mathrm{UR})\end{array}$ & $\begin{array}{c}\text { Espessura } \\
(\mathrm{mm})\end{array}$ & $\begin{array}{c}\text { Tensão } \\
\text { disruptiva } \\
\text { (volts) }\end{array}$ & $\begin{array}{c}\text { Rigidez } \\
\text { dielétrica } \\
\text { (volts/mm) }\end{array}$ \\
\hline Amostra 3.1 & 21,1 & 53 & 0,516 & 18,80 & 36,43 \\
\hline Amostra 3.1 & 21,1 & 51 & 0,512 & 18,90 & 36,91 \\
\hline Amostra 3.1 & 21,2 & 54 & 0,426 & 17,15 & 40,26 \\
\hline Amostra 3.2 & 21,0 & 55 & 0,436 & 17,00 & 38,99 \\
\hline Amostra 3.2 & 21,0 & 55 & 0,460 & 17,90 & 38,91 \\
\hline Amostra 3.2 & 21,1 & 54 & 0,558 & 19,50 & 34,95 \\
\hline Amostra 3.3 & 21,0 & 51 & 0,554 & 19,20 & 34,66 \\
\hline Amostra 3.3 & 21,0 & 53 & 0,455 & 17,25 & 37,91 \\
\hline Amostra 3.3 & 21,0 & 55 & 0,540 & 19,30 & 35,74 \\
\hline Amostra 3.4 & 21,0 & 51 & 0,383 & 15,40 & 40,21 \\
\hline Amostra 3.4 & 21,0 & 51 & 0,562 & 19,30 & 34,34 \\
\hline Amostra 3.4 & 21,0 & 50 & 0,556 & 18,95 & 34,08 \\
\hline Amostra 3.5 & 21,0 & 55 & 0,520 & 17,80 & 34,23 \\
\hline Amostra 3.5 & 21,0 & 54 & 0,517 & 18,05 & 34,91 \\
\hline Amostra 3.5 & 21,0 & 53 & 0,452 & 16,95 & 37,50 \\
\hline Amostra 3.6 & 21,0 & 53 & 0,466 & 17,20 & 36,91 \\
\hline Amostra 3.6 & 21,0 & 55 & 0,615 & 19,80 & 32,20 \\
\hline Amostra 3.6 & 21,0 & 55 & 0,542 & 18,60 & 34,32 \\
\hline Amostra 4.3 & 21,2 & 53 & 0,980 & 28,30 & 28,88 \\
\hline Amostra 4.3 & 21,2 & 55 & 0,684 & 25,40 & 37,13 \\
\hline Amostra 4.3 & 21,2 & 55 & 0,825 & 26,65 & 32,30 \\
\hline Amostra 4.4 & 21,2 & 51 & 0,611 & 22,20 & 36,33 \\
\hline Amostra 4.4 & 21,2 & 50 & 0,662 & 22,20 & 33,53 \\
\hline Amostra 4.4 & 21,2 & 51 & 0,642 & 23,30 & 36,29 \\
\hline Amostra 4.5 & 21,2 & 54 & 0,550 & 19,20 & 34,91 \\
\hline Amostra 4.5 & 21,2 & 52 & 0,561 & 19,00 & 33,87 \\
\hline Amostra 4.5 & 21,2 & 51 & 0,542 & 18,60 & 34,32 \\
\hline Amostra 4.6 & 21,1 & 55 & 0,504 & 17,05 & 33,83 \\
\hline Amostra 4.6 & 21,2 & 55 & 0,525 & 17,35 & 33,05 \\
\hline Amostra 4.6 & 21,2 & 55 & 0,595 & 18,50 & 31,09 \\
\hline & & & & & \\
\hline
\end{tabular}


(1) SAAD, A.L.G.; SAYED, W.M. and HASSAN, A.M. Journal of Applied Polymer Science, v. 73, ISS 13, p. 2675, 1999.

(2) JAKUBOWICZ, I.; YARAHMADI, N. and GIVERT, T. Polymer Degradation and Stability, v. 66, ISS 3, p. 415, 1999.

(3) PIELICHOWSKI, K. and HAMERTON, I. European Polymer Journal, v. 36, p. $171,2000$.

(4) KIM, Y.; CHO, W.J. and HA, C.S. Journal of Applied Polymer Science, v. 71, ISS 3, p. 415, 1999.

(5) GERLACH, D. Kunststoffe-plast Europe, v. 88, ISS 8, p. 1215, 1998.

(6) VENTRESCA, D.A. and BERARD, M.T. Journal of Vinyl \& Additive Technology, v.3, ISS 4, p. 274, 1997.

(7) ZURALE, M.M. and BHIDE, S.J. Mechanics of Composite Materials, v. 34, ISS 5, p. 463, 1998.

(8) KIM, W.; KIM, J.I.; CHUNG, K.Y.; PARK, P.W. and HA, C.S. PolymerKorea, v. 21, ISS 5, p.456, 1997.

(9) MANTOVANI, G.L.; PALLONE, K.C.; PESSAN, L.A. e HAGE JR, E. Anais $5^{\circ} \mathrm{CBPol}, 1999$.

(10) GOTTESMAN, R. T. and GOODMAN, D. Poly(vinyl chloride), Applied Polymer Science, cap. 18, p. 383, 1985

(11) FUJIYAMA, J. H. e DAL PIZZOL, M. F. Avaliação estrutural e morfológica de resinas de $\mathrm{PVC}, 5^{\circ}$ Congresso Brasileiro de Polímeros (12) RODOLFO JR., A.; NUNES, L. R. e ORMANJI, W. Tecnologia do PVC, Braskem, 2002. 
(13) SEARS, J. K.; TOUCHETTE, N. W. and DARBY, J. R. Plasticizers, Applied Polymer Science, p.611.

(14) BRAUN, D. and KÖMMERLING, S. DSC investigation on the thermal degradation of PVC in blends, Die Angewandte Makromolekulare Chemie, v. 195, p. 205, 1992.

(15) BILLMEYER JR., F. W. Textbook of Polymer Science, John Wiley \& Sons, 1984.

(16) AMERICAN SOCIETY FOR TESTING AND MATERIALS, ASTM D 2301-99, Standard specification for vinyl chloride plastic pressure-sensitive electrical insulating tape.

(17) Material didático de treinamento interno da 3M do Brasil - Metodologia 6 Sigma, DMAIC para Green Belts. 
"Boxplot" - gráfico com formato retangular para distribuição das amostras de um grupo.

Craqueamento - moléculas maiores se dividem em moléculas menores e mais simples.

"Heat tracer" - medidor de temperatura à distância por radiação infravermelha.

Valor K - parâmetro de peso molecular. H. Fikentscher definiu como índice de peso molecular de polímeros celulósicos. Depende da natureza e concentração do solvente e temperatura do teste, sendo a relação da viscosidade relativa com a concentração da solução, conforme fórmula abaixo:

$K=1000 \frac{1,5 \log \eta_{\text {rol }}-1+\sqrt{1+\left(\frac{2}{c}+2+1,5 \log \eta_{\text {rol }}\right) \times 1,5 \log \eta_{\text {rol }}}}{150+30,0 c}$

$\eta_{\text {ret }}=\frac{t}{t_{0}}$

sendo

$\eta_{\text {rol }}:$ viscosidade relativa

$t$ e $t_{0}$ : tempos de eluição da solução e solvente puro

$c$ : concentração da solução, $\mathrm{g} / \mathrm{L}$

Rigidez dielétrica - intensidade de campo (divisão da voltagem aplicada pela espessura) necessária para a ruptura do material sob condições específicas de teste. 